SUSANA FRANCISCHETTI GARCIA

\title{
ANÁLISE DA FLUÊNCIA VERBAL DE SURDOS ORALIZADOS EM PORTUGUÊS BRASILEIRO E USUÁRIOS DE LÍNGUA BRASILEIRA DE SINAIS
}

UNIVERSIDADE DE SÃO PAULO

SÃO PAULO 
Garcia, Susana Francischetti

Análise da Fluência Verbal de Surdos Oralizados

em Português Brasileiro e Usuários de Língua Brasileira de

Sinais.

São Paulo: s.n., 2001.

Dissertação (Mestrado) Universidade de São Paulo.

Área de Semiótica e Lingüística Geral

Orientador: Claudia Regina Furquim de Andrade 


\author{
Nome do arquivo: \\ Pasta: \\ capa1sfg \\ Modelo: \\ C:ITESESUBMETIDAS $\backslash$ SuzanaGarcia \\ aplicativos $\backslash$ Microsoft $\backslash$ Modelos\Normal.dot \\ Título: \\ SUSANA FRANCISCHETTI GARCIA \\ Assunto: \\ Autor: \\ USUARIO \\ Palavras-chave: \\ Comentários: \\ Data de criação: $\quad$ 29/10/2001 09:14 \\ Número de alterações: $\quad 2$ \\ Última gravação: $\quad$ 29/10/2001 09:14 \\ Gravado por: \\ USUARIO \\ Tempo total de edição: 0 Minutos \\ Última impressão: \\ 26/1/2001 10:23 \\ Como a última impressão \\ Número de páginas: 2 \\ Número de palavras: 79 (aprox.) \\ Número de caracteres: 454 (aprox.)
}


SUSANA FRANCISCHETTI GARCIA

\title{
ANÁLISE DA FLUÊNCIA VERBAL DE SURDOS ORALIZADOS EM PORTUGUÊS BRASILEIRO E USUÁRIOS DE LÍNGUA BRASILEIRA DE SINAIS
}

\author{
Dissertação apresentada ao programa de Pós-Graduação \\ do Departamento de Língüística da Faculdade de Filosofia, \\ Letras e Ciências Humanas da Universidade de São Paulo \\ para obtenção do grau de Mestre em Semiótica e Lingüística \\ Geral.
}

Orientador: Prof. Dra. Claudia Regina Furquim de Andrade

\section{SÃo PAULO}


BANCA EXAMINADORA

Presidente

$1^{\circ}$ (a) Examinador(a)

$2^{\circ}$ (a) Examinador(a) 
Aos meus pais, Geny e José, pela dedicação, amor, exemplo e ... paciência!! 
Eu não sou eu nem o outro, Sou qualquer coisa de intermediário:

Pilar da ponte de tédio Que vai de mim para o Outro. (Mário de Sá-Carneiro) 


\section{AGRADECIMENTOS}

À Professora Doutora Claudia Regina Furquim de Andrade, orientadora, amiga e exemplo de pesquisadora e profissional, pela orientação cuidadosa e pela imensa paciência com que conduziu esta pesquisa.

Às Professoras Doutoras Haydée Fiszbein Wertzner e Débora Befi Lopes, pela inestimável contribuição que deram à este trabalho durante o exame de qualificação.

À Professora Doutora Soraya Margall, pelo exemplo de trabalho com os surdos.

Aos meus irmãos Fernando, Ricardo, Helena, Doroty e Maria Rosa, pela amizade, incentivo e paciência durante a realização desta pesquisa, e pelo valioso apoio técnico nas situações mais inusitadas.

À Glória e Alberto, pelo incentivo, exemplo e amizade incondicionais.

Aos meus sobrinhos André, Mariana e Ana, pela compreensão e carinho.

Às amigas Célia, Adriana e Andréa, colegas de profissão, solidárias nos momentos de dúvida e companheiras nos momentos de alegria. 
Às diretoras e amigas do "Olga Benário", Andréa e Ana Paula, pelo apoio e amizade.

À todos os colegas do "Olga Benário", pela luta conjunta por uma boa escola para os surdos.

À Daniela, Fernanda e Fabíola, com quem aprendi muito sobre a fluência.

À amiga Cristina Midena, incentivadora e exemplo de dedicação à pesquisa e aos surdos.

À Sílvia Sabanovaite e Teresa Cristina, representantes da FENEIS em São Paulo, por possibilitarem a realização desta pesquisa.

À Soraia e ao Joel, pelo apoio durante a coleta dos dados.

Ao estatístico Marcos Maeda, pelo trabalho cuidadoso prestado.

Aos surdos que aceitaram participar desta pesquisa, meus agradecimentos e meu carinho pela valiosa coloboração. 


\section{SUMÁRIO}

LISTA DE TABELAS

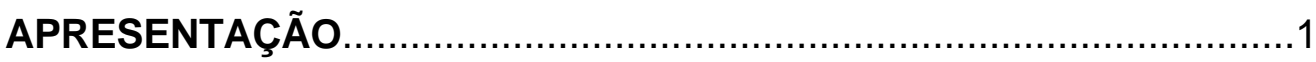

INTRODUÇÃO

MÉTODO

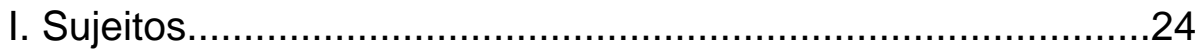

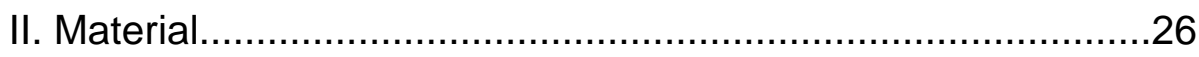

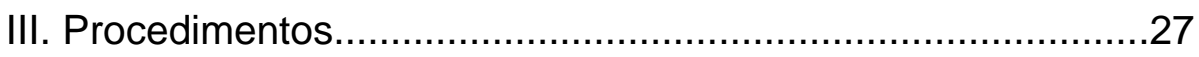

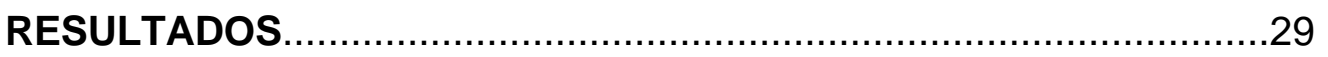

I. Análise Intra-Grupo....................................................31

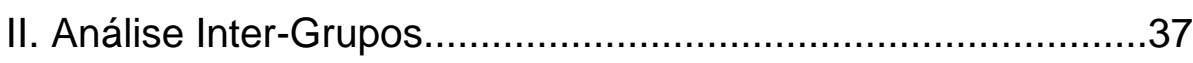

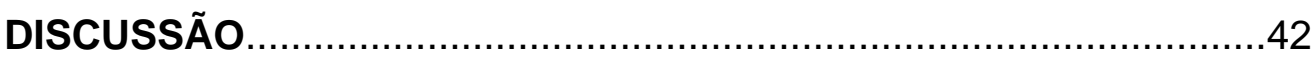

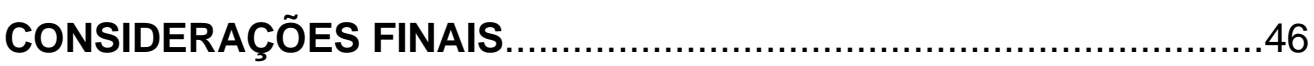

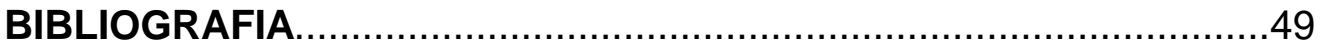

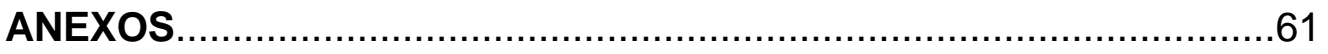




\section{LISTA DE TABELAS}

Pág.

Tabela 1: Produção oral e multimodal dos surdos quanto à velocidade de fala

Tabela 2: Produção oral e multimodal dos surdos quanto à tipologia das disfluências comuns

Tabela 3: Produção oral e multimodal dos surdos quanto às categorias de disfluências comuns

Tabela 4: Produção oral e multimodal dos surdos quanto à tipologia das disfluências gagas

Tabela 5: Produção oral e multimodal dos surdos quanto às categorias de disfluências gagas

Tabela 6: Produção oral e multimodal dos surdos quanto à freqüência de rupturas

Tabela 7: Comparação da velocidade da fala entre ouvintes fluentes e surdos

Tabela 8: Comparação da tipologia das disfluências entre ouvintes fluentes e surdos

Tabela 9: Comparação da freqüência de rupturas da fala entre ouvintes fluentes e surdos 


\section{LISTA DE FIGURAS}

Pág.

Figura 1: Velocidade de fala - comparação intra-grupo 35

Figura 2: Tipologia das disfluências - comparação intra-grupo 36

Figura 3: Freqüência de rupturas da fala - comparação intra-grupo 36

Figura 4: Velocidade de fala - comparação inter-grupos 39

Figura 5: Tipologia das disfluências - comparação inter-grupos 40

Figura 6: Freqüência de rupturas da fala - comparação inter-grupos 41 


\section{LISTA DE ANEXOS}

Pág.

ANEXO A: Termo de Consentimento Pós-Informação 62

ANEXO B: Tabela de Identificação dos Sujeitos 64

ANEXO C: Estudo Piloto 65

ANEXO D: Anamnese 71

ANEXO E: Protocolo de Avaliação da Fluência 72

ANEXO F: Figura 75

ANEXO G: Corpus - Avaliação da Fluência 76

ANEXO H: Tabela de Avaliação dos Juízes

ANEXO I: Tabelas Gerais 


\section{RESUMO}

GARCIA, S. F.. Análise da fluência verbal de surdos oralizados em Português Brasileiro e usuários de Língua Brasileira de Sinais. Dissertação apresentada ao Programa de Pós-Graduação do Departamento de Lingüística da Faculdade de Filosofia, Letras e Ciências Humanas da Universidade de São Paulo para obtenção do título de mestre em Semiótica e Lingüística Geral. São Paulo, 2001.

Este estudo tem como objetivo traçar o perfil da fluência verbal de surdos oralizados em Português Brasileiro, usuários de Língua Brasileira de Sinais, em relação aos aspectos de velocidade da fala, tipologia das disfluências da fala, e freqüência de rupturas da fala, tanto na produção oral quanto na produção multimodal. O perfil da fluência foi investigado através da análise perceptual de amostras de fala de 12 indivíduos adultos surdos profundos congênitos. A metodologia de coleta e a análise da fluência foi baseada em protocolo brasileiro de avaliação da fluência. Os dados obtidos foram comparados intra-grupo, ou seja, a produção oral dos surdos com sua produção multimodal, e inter-grupos, a produção dos surdos com os parâmetros de fluência de ouvintes falantes de Português Brasileiro. Os resultados indicam que a fluência da fala dos surdos, tanto na produção multimodal quanto na produção oral são diferentes da fluência dos ouvintes. A velocidade da fala dos surdos é mais lenta que a dos ouvintes. Quanto à tipologia das disfluências da fala, os surdos apresentam resultados diferentes dos ouvintes (exceto na produção oral, para disfluências comuns). A freqüência de rupturas da fala dos surdos é superior à dos ouvintes (exceto na produção multimodal, para a porcentagem de descontinuidade de fala). Este estudo evidencia a necessidade de novas pesquisas sobre a fluência verbal dos surdos.

PALAVRAS-CHAVE: surdez, fluência, adultos, fala, língua de sinais. 


\begin{abstract}
GARCIA, S.F.. Analyses of the verbal fluency of deaf individuals with oral Brazilian Portuguese language and users of the Brazilian Sign Language. Dissertação apresentada ao Programa de Pós-Graduação do Departamento de Lingüística da Faculdade de Filosofia, Letras e Ciências Humanas da Universidade de São Paulo para obtenção do título de mestre em Semiótica e Lingüística Geral. São Paulo, 2001
\end{abstract}

This research aimed to determine the verbal fluency profile of deaf individuals with oral Brazilian Portuguese language and users of the Brazilian Sign Language, in relation to speech rate, type of disfluencies and frequency of speech disruptions, in the oral and multimodal production. The fluency profile was investigated through the perceptual analyses of the speech samples of 12 deaf adults with severe congenital hearing loss. The adopted methodology and the fluency analyses were based on the Brazilian protocol of fluency analyses. The obtained data was analysed within the group, that is, comparing the oral production of the deaf individuals to their multimodal production, and between groups, that is, comparing the oral production of the deaf individuals to the oral production of hearing individuals speakers of the Brazilian Portuguese. The results indicate that the fluency of speech of deaf individuals, in the multimodal and in the oral production, are different than hearing individuals. The speech rate of deaf individuals is slower than that presented by hearing individuals. In relation to the type of disfluencies presented, the deaf individuals present different results than that observed in hearing individuals (except in the oral production for the common disfluencies category). The frequency of the speech disruptions presented by the deaf individuals is superior to that of the hearing group (except for the multimodal production for the percentage of speech discontinuity category). This study emphasizes the need of more research about the verbal fluency of deaf individuals.

KEY-WORDS: deaf, fluency, adults, speech, sign language 
Nome do arquivo:

Pasta:

Modelo: ap

Título:

Assunto:

Autor:

Palavras-chave:

Comentários:

Data de criação:

Número de alterações:

Última gravação:

Gravado por:

Tempo total de edição:

Última impressão:

Como a última impressão

Número de páginas: 12

Número de palavras: 1.631 (aprox.)

Número de caracteres:9.299 (aprox.) capa2sfg

C:ICOLEGIADOS\FFLCH $\backslash$ SuzanaGarcia

$\mathrm{C}$ : Documents and SettingslclientelDados de

Modelos\Normal.dot

USUARIO

29/10/2001 09:15

2

29/10/2001 09:15

USUARIO

0 Minutos

28/1/2001 08:14 
APRESENTAÇÃO 
Durante os últimos anos a fluência verbal e a surdez têm sido muito investigadas. Na área da fluência verbal os pesquisadores têm se preocupado com uma melhor compreensão dos parâmetros de fluência nas diferentes faixas etárias, com a utilização de instrumentos de avaliação objetivos, e com a adaptação destes instrumentos a outros idiomas para verificar quais são os parâmetros em diferentes populações.

$\mathrm{Na}$ área da surdez, as pesquisas têm sido direcionadas para a importância da língua de sinais no processo de aquisição e desenvolvimento da linguagem dos surdos, além da contraposição dos principais métodos terapêuticos e educacionais (oralismo, comunicação total e bilingüismo) na busca pela eficácia no trabalho com os surdos.

Acompanhando estas vertentes de pesquisa, avaliou-se a fluência verbal de surdos adultos oralizados em Português Brasileiro e usuários de Língua Brasileira de Sinais nos aspectos da velocidade da fala, da tipologia das disfluências e da freqüência de rupturas da fala, utilizando um instrumento de avaliação para os falantes do Português Brasileiro proposto por Andrade (2000b).

A escolha dessa população específica ocorreu devido à experiência clínica dessa pesquisadora acumulada, por sete anos no atendimento à uma comunidade escolar de surdos de diferentes faixas etárias. Esta atuação mostrava que a fluência daqueles indivíduos era diferente da apresentada pelos ouvintes e que esta diferença não estava centrada em aspectos articulatórios mas sim discursivos.

O fluxo da fala era lento e apresentava empréstimos da língua de sinais em vários momentos do discurso. Mesmo sujeitos considerados bem oralizados por profissionais experientes no atendimento de surdos, percebiam que sua fala destoava do padrão dos ouvintes e manifestavam a necessidade de algum trabalho específico para melhoria da fluência de sua fala. 
No levantamento bibliográfico realizado observaram-se poucos estudos que abordassem o aspecto da fluência na linguagem do surdo, e quando este aparecia era identificado na maior parte das vezes com problemas ligados à produção da voz. Deste modo, considera-se objetivo geral desta pesquisa traçar o perfil da fluência verbal em surdos bilíngües, quanto à produção oral, ou seja, o discurso verbal emitido pelo modo oral de comunicação; e quanto à produção multimodal, ou seja, o discurso verbal emitido através do modo oral, associado às articulações sem som e aos sinais da Língua Brasileira de Sinais, tendo sido baseado em quatro hipóteses:

1 - A velocidade de fala dos surdos é menor que a velocidade de fala dos ouvintes, tanto para o número de palavras por minuto quanto para o número de sílabas por minuto;

2 - A tipologia das disfluências da fala dos surdos é diferente daquela encontrada nos ouvintes, tanto para as disfluências comuns quanto para as disfluências gagas;

3 - A freqüência das rupturas na fala dos surdos é maior que aquela encontrada na fala dos ouvintes;

4 - A fluência da fala dos surdos na produção multimodal é semelhante à fluência da fala dos ouvintes. 
INTRODUÇÃO 
A linguagem, segundo Saussure (1972), é uma faculdade que nos é dada pela natureza, pertencendo ao domínio individual e social. A língua constitui algo adquirido e convencionado, é um produto social da faculdade da linguagem e um conjunto de convenções necessárias adotado pelo corpo social para permitir o exercício desta atividade pelos indivíduos. A fala é um ato individual de vontade e inteligência, que carrega tanto as combinações pelas quais o falante realiza o código no propósito de exprimir seu pensamento pessoal, como o mecanismo psico-físico que lhe permite exteriorizar estas combinações.

As intensas trocas sociais possibilitadas por uma comunicação eficiente ajudam o homem a construir sua visão de mundo. Para Pais $(1976,1986)$, o código lingüístico desempenha um papel senão exclusivo, pelo menos preeminente na organização de uma visão de mundo. A concordância do código usado pelos interlocutores é de grande importância para a compreensão da mensagem. Quando os interlocutores são falantes nativos da mesma língua, teremos que os seus códigos, sem serem idênticos, apresentam uma ampla interseção, ou seja, ocorre a comunicação. Porém se um deles não é falante nativo da língua, e aprendeu a língua utilizada como segunda, esta interseção será menor e ainda contará com a interferência entre os sistemas semióticos da língua materna e da segunda língua deste interlocutor como fonte de ruído.

Segundo Goss (1989), a linguagem funciona como uma espécie de organizador do mundo, uma ferramenta para criá-lo e compreendê-lo. Através dela as sociedades foram se organizando, e construiu-se o que entendemos atualmente por civilização. A organização do pensamento depende diretamente da competência que um indivíduo tem em relação à sua linguagem.

Nas considerações de Luján (1993) a linguagem é a característica que define a condição de ser humano, tanto que aqueles que não têm possibilidade de desenvolver linguagem por qualquer motivo, não são considerados como interlocutores válidos pelo resto dos integrantes da sociedade. 
Andrade (1996) coloca que a comunicação é um dos atributos pessoais mais importantes, determinando a visão de mundo e a qualidade do relacionamento entre o homem e a sociedade. A habilidade comunicativa facilita a resolução de problemas, ajustes pessoais, sucesso educacional e profissional.

O domínio de um língua implica, segundo Lopes (1997) e Fernandes (1999), no domínio das regras gramaticais e na manipulação da língua, produzindo assim conhecimentos novos através de um comportamento criativo do falante, decorrendo do contato com a língua e do desempenho em qualquer uma de suas modalidades.

Em suas considerações, Ghisi (1993) ressalta que a fala, apesar de não ser a única forma de expressão da linguagem, é a forma de comunicação mais freqüente nas comunidades sociais majoritárias.

Segundo Schochat (1996) a fala é um fenômeno primeiramente auditivo. A percepção da fala envolve redundâncias intrínsecas ao ouvinte (diversas vias e tratos auditivos) e redundâncias extrínsecas ao ouvinte (complexidade do estímulo de fala, várias pistas acústicas).

Para Behlau e Russo (1993) a percepção dos sons da fala inclui a recepção e interpretação dos padrões de fala; a discriminação entre sons de diferentes espectros, durações, características temporais, formas seqüenciais e ritmo; e o reconhecimento, a memorização e a compreensão de unidades de fala dentro de determinado sistema lingüístico. Em seu trabalho as autoras fazem uma descrição através da espectrografia, das características acústicas do Português Brasileiro, verificando que alguns fonemas se situam em níveis de audição inferiores ao considerado limiar de normalidade, o que se não traz maiores problemas para indivíduos com audição normal, ou mesmo para adultos com perdas adquiridas, traz problemas de inteligibilidade da fala para indivíduos com perdas auditivas congênitas. 
Segundo Peters (1983), as informações são armazenadas por nosso sistema lingüístico através de segmentações de unidades lingüísticas. Todas as unidades lingüísticas podem ser segmentadas e estes segmentos podem então ser armazenados em várias partes da memória. $O$ próprio processamento lingüístico, bem como o tipo e a quantidade de dados a serem armazenadas são fatores que afetam a segmentação.

Como colocado por Goss (1989) as informações não verbais, compostas por elementos paralingüísticos, pela emoção e pela memória, seriam uma espécie de suporte da comunicação verbal, sendo de grande importância para a efetividade da comunicação e para a aquisição de linguagem. Para a autora, a fala espontânea, além de mais freqüente em nossa vida diária, é caracterizada por falhas ocasionais na fluência. Um interlocutor que não comete falhas ocasionais não tem tanta credibilidade quanto um que comete, pelo fato de parecer pouco humano e pouco real.

Segundo Maclay e Osgood (1959) os falantes operam simultaneamente dois tipos de escolha para o enunciado: a lexical (ou semântica) e a gramatical (ou estrutural). $O$ aparecimento natural das pausas e outros fenômenos de hesitação influenciam o interlocutor quanto à sinceridade do falante. Fatores externos podem aumentar o nível das hesitações. A hesitação está relacionada à dinâmica de seleção gramatical e lexical. A pausa ocorre antes de palavras de importância lexical e gramatical.

Em suas considerações, Marcushi (1987) coloca que a fala é permeada por elementos verbais, prosódicos e não lingüísticos, chamados marcadores conversacionais, subdivididos em quatro grupos: marcador simples (uma só palavra: interjeição, advérbio, verbo, adjetivo, conjunção, pronome, etc.); marcador composto (apresenta um caráter sintagmático com tendência à cristalização, ex.: então daí, aí depois, quer dizer, digamos assim); marcador oracional (corresponde a pequenas orações que se apresentam nos diversos tempos e formas verbais ou modos 
oracionais assertivo, indagativo, exclamativo, ex.: eu acho que, quer dizer, então eu acho); marcador prosódico (associa-se a algum marcador verbal mas realiza-se por meio de recursos prosódicos). Fazem parte deste grupo a entonação, a pausa, a hesitação, o tom de voz, entre outros.

Para Scarpa (1995), é difícil falar rápido e acuradamente ao mesmo tempo, e este tipo de relação de troca entre precisão articulatória e fluência é explorada como uma propriedade emergente da dinâmica auto-organizadora do processo fonético.

Segundo Fávero, Andrade e Aquino(2000) a língua falada contém um grande volume de elementos pragmáticos, destacando-se as pausas, hesitações, prolongamentos de vogais e consoantes, repetições, ênfases e truncamentos. Tais elementos são de natureza lingüística mas não apresentam caráter verbal.

As autoras colocam ainda que as pausas são decisivas na organização dos textos conversacionais, podendo ser curtas, médias ou longas. São freqüentes no final de unidades discursivas e geralmente estão acompanhadas de outros marcadores. Podem ocorrer no início das unidades como hesitação (pausa preenchida). As pausas longas quando ocorrem no diálogo propiciam a troca de turnos conversacionais, e no monólogo têm função cognitiva, possibilitando o planejamento verbal.

Com base na Teoria da Função Neuropsicolingüística proposta por Perkins, Kent e Curlee (1991), Andrade (2000a) considera que para que a fala seja fluente, dois sistemas operacionais neurais, o simbólico e o de sinais, devem estar temporalmente equilibrados antes que a mensagem gerada chegue ao córtex motor. O sistema simbólico integra os componentes cognitivos, lingüísticos e segmentais da fala, determinando a forma e o conteúdo da mensagem. Responde pela segmentação de saliências fonológicas pontuais (ritmo e entonação) e fragmentais (começo, meio e fim). O sistema de sinais integra os componentes paralingüísticos e prosódicos da fala, determinando a intensidade, altura, duração e valor qualitativo da sílaba. 
Para Andrade (2000a) a fluência depende da integração harmônica não só entre o processamento auditivo, da linguagem e da fala, mas também dos processamentos dos centros de controle das emoções e da memória, propiciando um fluxo suave e contínuo da fala.

Starkweather e Givens-Akerman (1997) definem a fluência como uma variável multidimensional composta de continuidade, ritmo e esforço. A fala fluente é produzida continuamente, sem esforço e numa velocidade apropriada. Para os autores, existiriam no mínimo quatro áreas envolvidas neste comportamento, a saber, a coordenação motora e oral, a habilidade lingüística, a habilidade cognitiva e a maturidade social-emocional.

Quanto a este aspecto, Fávero, Andrade e Aquino (2000) colocam que as atividades de formulação do texto oral podem ser subdivididas em dois tipos, a de formulação strito senso, quando o locutor não encontra problemas de processamento e linearização; a de formulação latu senso, quando o locutor encontra problemas de formulação e deve resolvê-los. As situações que desencadeiam problemas são hesitações, paráfrases, repetições e correções.

Segundo Prins et al. (1997), Silverman e Ratner (1997) e Andrade (1999), as disfluências não são exclusivas da fala de gagos. Os fluentes também apresentam rupturas na fala, o que torna necessário o conhecimento dos padrões de fluência de gagos e fluentes, possibilitando a diferenciação destes dois grupos.

Em suas considerações, Andrade (2000a) ressalta que o processo que gera as disfluências é o mesmo para todos os falantes, e que o grau de fluência varia de indivíduo para indivíduo, dependendo do dia, das emoções, do domínio sobre o tema da conversação e das diferentes situações de fala do dia-a-dia. 
Em estudo elaborado para avaliar os efeitos do léxico na latência das respostas de adultos gagos e não gagos, Prins et al. (1997) colocam que palavras pouco utilizadas têm um efeito importante no tempo de recuperação $e$ encadeamento das palavras para a expressão entre os gagos, independente de seu nível de vocabulário.

Howell, Au-Yeung e Sackin (1999) observaram que falantes fluentes utilizam a repetição e a hesitação em palavras funcionais, isto é, com pouco conteúdo semântico, para retardar a produção de palavras de forte conteúdo semântico, como uma estratégia para produzi-las de forma fluente.

Segundo Hubbard (1998), as quebras de fluência da fala estão relacionadas a estrutura métrica das frases. A posição da palavra na frase, bem como a localização da sílaba tônica na palavra, também afeta a ocorrência de quebras de fluência.

Nas considerações de Leeper e Cullata (1995) a interrupção na fluência da fala pode tanto ser considerada normal, como um sintoma de uma patologia da fala ou uma desordem neurológica. O que determina o diagnóstico diferencial é o tipo e o nível das disfluências da fala produzidas pelos falantes.

Sobre a tipologia das disfluências, Campbell e Hill (1994) e Andrade (2000a, 2000b) propõem uma divisão em dois grupos segundo a característica das rupturas, a saber, disfluências comuns e disfluências gagas. Para Andrade (2000a), as disfluências comuns são aquelas apresentadas por todos os falantes e refletem fundamentalmente as incertezas ou imprecisões lingüísticas, ou ainda, objetivam ampliar a compreensão da mensagem. As disfluências gagas são aquelas que embora possam ocorrer esporadicamente para todos os falantes, são sugestivas de um maior comprometimento. 
Para Silverman e Ratner (1997), algumas variáveis lingüísticas parecem afetar a fluência na população adulta. Os autores colocam que ocorre uma diminuição do efeito da complexidade sintática sobre a ocorrência de disfluências gagas. Porém o mesmo efeito promove um aumento nas disfluências normais tanto para adolescentes gagos quanto para adolescentes não gagos. Concluem que a tipologia de disfluências normais, mesmo nas pessoas que gaguejam, é de fato um comportamento comum, ao invés de uma desordem característica da fluência.

Segundo Starkweather e Givens-Akerman (1997) a velocidade de fala pode ser medida tanto pelo fluxo de palavras por minuto (mede a taxa de produção da informação), quanto pelo fluxo de sílabas por minuto (mede a taxa de velocidade articulatória, ou seja, a velocidade de modificação das estruturas da fala). Outro parâmetro diferencial do grau de fluência é quanto à freqüência das rupturas, que mede a taxa de rupturas, total e gagas, durante o discurso. Essa taxa pode ser determinada pelo número de disfluências por minuto (número total de rupturas, comuns e gagas) e pela porcentagem de sílabas gaguejadas (percentual de rupturas gagas).

Nas considerações de Block e Killen (1996) e Andrade (1999, 2000a) os parâmetros de velocidade normal de fala são importantes não só no diagnóstico diferencial das patologias como também para os procedimentos terapêuticos ligados à fluência.

A surdez segundo Northern e Downs (1989), Yantes (1989) e Prinz (1989) é uma perda auditiva neurossensorial de grau severo a profundo (superior a $70 \mathrm{dBNA}$, na média das freqüências de 500, 1000 e 2000 Hertz), um tipo de privação sensorial que impede a aquisição natural da linguagem, podendo ter um efeito devastador no desenvolvimento desta e na competência comunicativa.

Segundo levantamento realizado junto a três Serviços de Saúde especializados no atendimento a crianças surdas na cidade de São Paulo (Fórum, 1995) revelou-se que em média 50\% das causas das deficiências auditivas destes 
sujeitos poderiam ter sido prevenidas e são poucos os programas governamentais dedicados à prevenção da surdez.

Goldfeld (1997) enfatiza que a realidade do surdo brasileiro ainda é muito precária. Muitos surdos não têm acesso a tratamento fonoaudiológico especializado e, a não ser em grandes centros urbanos, não existem comunidades de surdos organizadas, lugares onde a LIBRAS (Língua Brasileira de Sinais) possa ser utilizada e divulgada.

Para Prinz (1989) e Stewart (1993), o problema primário na reabilitação e educação de deficientes auditivos refere-se à forma de linguagem e tipo de comunicação que devem ser usados. Stewart (1993) ressalta que a aquisição da linguagem irá ocorrer se ela for prática e significativa, e se a criança tiver acesso à sua forma e ao seu significado.

Para Balieiro, Pupo e Ficker(1997), o acesso ao atendimento fonoaudiológico precoce está diretamente ligado às condições sócio-econômicas das famílias, visto que o atendimento fonoaudiológico para indivíduos com perda severa dura aproximadamente de 3 a 8 anos e para os indivíduos com perda profunda de 10 a 16 anos, e existem poucos serviços públicos com estrutura para realizar este atendimento

Nas considerações de Skliar (1997), não é só o tipo e o grau de perda auditiva e de algumas variáveis a elas relacionadas (como a idade de diagnóstico e do uso ou não de aparelhos para surdez) que vai determinar o grau de desenvolvimento e integração deste sujeito à sociedade em que vive. Para o autor, uma série de fatores contribuem para que isto ocorra ou não: se o surdo vive numa sociedade periférica ou em uma sociedade central, se sua família é surda ou ouvinte, se em seu país existem medidas de prevenção primárias, secundárias e terciárias, se as instituições educativas a seu alcance promovem ou não as mesmas possibilidades pedagógicas que para os ouvintes, se os meios de comunicação de 
massa oferecem alternativas compensatórias para o acesso à informação, como por exemplo as legendas nos programas de televisão.

Tal visão é compartilhada por Bueno (1998), que destaca ainda que embora existam diferenças lingüísticas entre os surdos e os ouvintes, a origem da diferença é a perda de audição, uma patologia. O autor coloca ainda, que como patologia, a deficiência auditiva deve concentrar todos os esforços da sociedade para que seja prevenida, e os surdos devem ser respeitados em sua diferença.

Para Massone (1993), Ghisi (1993) e Skliar (1997), durante muitos anos predominou na lingüística e nas práticas terapêuticas uma concepção logocêntrica, ou seja, que identificava a linguagem com a língua oral e, mais especificamente, com os mecanismos da produção da linguagem. Ainda segundo as considerações destes autores, esta concepção fez com que desde o final do século XIX até meados dos anos 60 do século $\mathrm{XX}$, houvesse um predomínio das práticas ditas oralistas, tanto na lingüística como na atuação dos profissionais da educação especial e da reabilitação dos surdos.

Segundo Moura (1993), Lopes (1997) e Behares (1993), poucos surdos alcançaram uma oralização suficientemente boa, numa abordagem puramente oralista, para que pudessem interagir e se integrar no mundo dos ouvintes.

Tal visão é compartilhada ainda por Goldfeld (1997), para quem, apesar de todos os esforços de profissionais e dos avanços tecnológicos, a língua oral até o presente momento não pode ser adquirida pela criança surda espontaneamente, ou seja, através de diálogos. Para a autora, faz-se necessário que a criança se submeta a um longo e intensivo atendimento fonoaudiológico que apesar de essencial para seu convívio com a comunidade ouvinte, não pode ser comparado à aquisição natural e espontânea de uma língua. 
Em suas considerações, Northern e Downs (1989) colocam que as práticas terapêuticas que utilizam o código oral exclusiva ou preferencialmente, preconizam que a audição é a mais conveniente modalidade perceptual pela qual a criança aprende a fala e a linguagem. A criança necessita de um treinamento intensivo das habilidades auditivas, possível através do uso do aparelho de amplificação sonora ou prótese auditiva, além de um treinamento intensivo da fala. Segundo este método, a criança estimulada responde melhor ao seu ambiente, tem uma qualidade de voz mais natural com fala fluente, aprende a linguagem mais fácil e naturalmente e se torna uma melhor leitora labial. Para obter melhores resultados, o diagnóstico precoce é imprescindível, bem como a adaptação e o uso regular dos aparelhos de amplificação sonora, ou próteses auditivas.

Para Bevilacqua e Formigoni (1998), a abordagem oralista, ou auri-oral, é um tipo de intervenção terapêutica que prioriza a alteração primária da criança, ou seja, a audição. Tem como objetivo auxiliar a criança a utilizar sua audição residual, possibilitando desse modo que ela cresça aprendendo a ouvir e falar, de tal forma que possa aumentar seus conhecimentos, suas experiências de vida, e se tornar uma pessoa integrada e participante da sociedade em geral.

Segundo Menegotto, Almeida, lório (1996), lório (1997) e Coutinho (1997) o aparelho de amplificação sonora, ou prótese auditiva, seria um sistema portátil que captaria o som do meio ambiente, aumentaria sua intensidade, e o forneceria amplificado ao usuário. lório ressalta que o objetivo da adaptação das próteses auditivas é assegurar que os sons de fala sejam audíveis sem serem excessivamente intensos. Entretanto Coutinho destaca que uma boa adaptação das próteses auditivas depende de vários fatores, entre eles o tipo de perda do sujeito, o ambiente freqüentado por ele, a idade de diagnóstico da perda auditiva.

Para Schochat (1996), a performance de percepção de fala pode ser influenciada por uma série de fatores, que podem ser divididos em 4 categorias: o sinal (fatores fonético-fonológicos e de prosódia), o falante (intensidade da voz, precisão articulatória, velocidade de fala), o meio ambiente (presença de ruído e/ou 
reverberação) e o ouvinte (audição periférica e central). Segundo a autora, a performance de um indivíduo com perda auditiva seria determinada primeiramente pela quantidade de informação acústica disponível para ele. Porém a maioria das pessoas com perdas auditivas teria dificuldades em perceber as consoantes, por exemplo, pois estas possuem características acústico-articulatórias (menor intensidade, maior concentração de informações nas freqüências agudas) que vão de encontro à dificuldade destes indivíduos.

Nas considerações de Kozlowski (1997) o surdo necessitaria de várias pistas para entender a linguagem falada, sendo uma destas pistas a leitura labial. Porém a informação obtida através da leitura labial isolada não é suficiente para permitir que uma pessoa com deficiência auditiva entenda a mensagem completamente. A performance em percepção de fala melhora quando se combinam os fatores auditivos e visuais.

Para Ciccone (1996), apesar dos avanços tecnológicos que permitem um maior acesso à linguagem oral pelos surdos, em todo mundo grande parte dos surdos insiste em usar a língua de sinais. A autora descreve a comunicação total, uma filosofia de trabalho voltada para o atendimento e a educação da pessoa surda, que utiliza técnicas e recursos para estimulação auditiva, tais como adaptação de aparelho de amplificação sonora, leitura labial, oralização, leitura e escrita, além da prática de qualquer estratégia que permita o resgate da comunicação, total ou parcialmente, bloqueada pela perda de audição.

Ao descreverem os recursos tecnológicos disponíveis para desenvolver a reaferentação visual na reabilitação oral de deficientes auditivos, Lichtig et al. (1997) colocam que desenvolver uma comunicação oral inteligível continua sendo um problema, apesar da melhoria das tecnologias dos aparelhos de amplificação sonora. As autoras colocam ainda que a reaferentação visual pode auxiliar na melhoria dos padrões articulatórios dos surdos, mas não resolve o problema da generalização de novos padrões por estes indivíduos. 
Para Dagenais et al. (1994), a palatografia também pode ser utilizada como um recurso de reaferentação proprioceptiva, auxiliando os surdos a melhorarem suas emissões, principalmente, de consoantes.

Segundo Botelho (1998), no campo das interações discursivas, em graus variados, o aprendizado da língua oral pelos surdos ainda é intensamente perseguido. Aprender a falar converte-se freqüentemente em obsessão e obrigatoriedade. Falar é concebido como sinônimo de ser pessoa. Entretanto, mesmo os surdos oralizados dominam apenas parcialmente a língua oral. $\mathrm{O}$ tipo de trabalho oferecido não atende às necessidades interativas dos sujeitos surdos.

Para Behares (1993), na concepção tradicional de surdez, o conceito de déficit lingüístico está implícito, já que supõe que a única forma de adquirir linguagem é através do canal auditivo-oral, justamente o que é deficiente no surdo. $\mathrm{O}$ autor ressalta que a grande maioria das pessoas surdas são bilíngües, com um tipo muito especial de bilingüismo, que compreende não somente duas línguas com funções sociais diferentes, como também diferentes canais de organização: audiooral e visual-espacial. Neste caso a oralidade dos surdos seria um dos componentes de sua gestualidade.

Devemos distinguir bilingüismo como uso de duas línguas e bilingüismo como modalidade terapêutica e de ensino. Para Quadros (1997) e Lacerda(1998), o bilingüismo é uma proposta de ensino usada por escolas que se propõem a tornar acessível à criança duas línguas no contexto escolar. Seu objetivo é propiciar à criança surda um desenvolvimento cognitivo e lingüístico equivalente ao verificado na criança ouvinte, desenvolvendo assim uma relação de harmonia com os ouvintes. Nesta pesquisa, nos referimos ao bilingüismo como uso de duas línguas.

Segundo Brito (1995) o canal visual-espacial pode não ser o preferido pela maioria dos seres humanos para o desenvolvimento da linguagem posto que a maioria das línguas naturais são orais-auditivas, porém é uma alternativa que revela 
de imediato a força e a importância da manifestação da faculdade de linguagem nas pessoas.

Para Stokoe (1996) e Hickok, Bellugi e Klima (1996), as línguas de sinais são línguas naturais, regidas por princípios universais, com estrutura lingüística, com níveis sintáticos, morfológicos e fonológicos. No nível fonológico, os sinais são fracionados em elementos sublexicais, incluindo formas repetidas das mãos, localização das articulações e movimentos dos membros/mãos. Existem diferenças sistemáticas "fonéticas" regulares entre a língua de sinais principal e um "sotaque" quando um usuário nativo de uma língua de sinais aprende outra. No nível morfológico, a língua de sinais tem desenvolvido marcadores gramaticais que servem como derivações e inflexões de morfemas. No nível sintático, a língua de sinais especifica relações entre sinais através de, entre outras coisas, a manipulação dos sinais no espaço, onde diferentes relações espaciais sistematizadas comunicam diferentes significados.

Entre as diferenças existentes entre as línguas orais e as línguas de sinais, Brito (1995) salienta a ordem seqüencial linear da fala e a simultaneidade dos parâmetros na construção dos sinais, assim como a simultaneidade de sinais na formação de várias orações das línguas de sinais. A autora ressalta ainda que apesar de se passar em espaço multidimensional, as línguas visuais-espaciais também fazem uso da linearidade temporal, e que as línguas orais nem sempre são exclusivamente unidimensionais, como no caso da seqüência de palavras acompanhadas de entonação e no caso dos traços distintivos dos fonemas há simultaneidade.

Nas considerações de Skliar (1997) e Kyle (1999) a língua de sinais é uma língua minoritária, relegada ao uso em situações informais e cotidianas entre pares, tendo uma função intra-grupal. A modalidade oral de uma língua funciona como a segunda língua, majoritária, e é utilizada segundo as possibilidades individuais dos surdos, em interação com os ouvintes e quando o interesse é a necessidade de integração. O surdo necessita de ambas as línguas com um desenvolvimento 
competente: a língua de sinais para sua comunicação entre surdos e a segunda língua para integrar-se à comunidade ouvinte.

Segundo Behares e Peluso (1997), o conceito de primeira língua faz referência a fatores temporais: é aquela língua que ingressa em primeiro lugar no repertório lingüístico da criança. Os autores destacam que quando se afirma que a língua de sinais é a língua natural do surdo, faz-se referência ao fato de que na presença dela o acesso do surdo é imediato, tanto por sua estrutura visual-espacial quanto pelo fato de ser a língua de sua comunidade de referência, tornando possível a interação espontânea.

Para Maher (1997), o bilíngüe é sempre capaz de se desempenhar melhor numa língua do que na outra a depender do gênero/tipo de discurso e do seu estado emocional no momento da comunicação. A mudança de código e os empréstimos lingüísticos são recursos comunicativos poderosos dos quais o bilíngüe lança mão com freqüência para pragmaticamente atribuir sentidos vários aos seus enunciados: para expressar afetividade, relações de poder, mudanças de tópico, identidade social/étnica. Entretanto questões que envolvem a necessidade ou o desejo de reafirmação de identidade étnica ou social, freqüentemente afetam o grau de competência exibida pelo bilíngüe.

Nas considerações de Gargallo (1993), os aprendizes de uma segunda língua apresentam erros no processo de aquisição da mesma, que podem ser decorrentes da influência da primeira língua bem como erros de aproximação da primeira língua com a segunda língua do falante. Estes erros podem ser classificados segundo a tipologia como: omissão, adição (marcação dupla, regularização, adição simples), formação errônea e ausência de ordem oracional. As omissões seriam decorrentes da não internalização ou do desconhecimento da regra gramatical e pela carência de vocabulário. As adições decorreriam do uso excessivamente fiel das regras gramaticais por hipercorreção lingüística. As formações errôneas decorreriam do desconhecimento ou da insegurança no uso de sinônimos. E a ausência de ordem 
ou a ordem incorreta dos elementos frasais, ocorreriam nas línguas onde a ordem oracional é mais rígida.

Margall (1994), em estudo comparando os erros das emissões de surdos estimulados através da comunicação total com surdos estimulados pelo método oral, relata que as produções dos dois grupos são percebidas de modo semelhante pelos ouvintes.

Em seus estudos Meline (1997) e Miller (1997) descrevem padrões de aquisição dos processos fonológicos pelos surdos, identificando alguns processos mais comuns, como a eliminação da consoante final, a simplificação de líquidas e a redução dos grupos consonantais. Meline (1997), considera ainda que a severidade do grau da perda auditiva sozinha não faz uma previsão perfeita da performance de fala. Outras variáveis importantes incluem idade de início da perda auditiva (prélingüística versus pós-lingüística), o uso do aparelho de amplificação sonora, e a estimulação ambiental.

Em pesquisa realizada com surdos na faixa etária de 7 a 21 anos, Fletcher e Daly (1976) detectaram, entre outras coisas, que o grupo de surdos falava muito mais lentamente que o grupo controle com audição normal. Na leitura de um texto comum aos dois grupos, a média de palavras por minuto produzida pelos surdos foi de 95 palavras por minuto, contra 173 palavras por minuto do grupo controle. Eles notaram inclusive que o grupo dos surdos omitia algumas palavras durante a leitura.

Para Gold (1980), a fala do surdo caracteristicamente tem problemas distintos de sincronização, entonação e qualidade vocal, sendo freqüentemente descrita como lenta, com durações prolongadas tanto das sílabas tônicas quanto das átonas, as passagens entre as palavras são freqüentemente caracterizadas por sons intrusos, e pausas excessivas e inadequadas são freqüentemente ouvidas. Com freqüência crianças com deficiência auditiva tendem a usar igual acentuação em todas as palavras, pausando após a emissão de cada palavra. Além disso somente 
$20 \%$ dos ouvintes não habituados com a fala do surdo conseguem compreendê-la em situações espontâneas.

Em suas considerações, Prinz (1989) cita algumas pesquisas americanas que tentam analisar e resumir os padrões da linguagem oral dos surdos; uma delas coloca que os erros de articulação do surdo refletem uma desorganização dos padrões de sincronização interarticular em vez de simplesmente colocações articulatorias inapropriadas. Outra sugere que nenhum parâmetro ou conjunto de parâmetros articulatórios pode responder pela inteligibilidade de fala ruim dos deficientes auditivos.

Northern e Downs (1989) e Goldfeld (1997) descrevem as dificuldades de comunicação do surdo principalmente na modalidade oral da linguagem, como por exemplo, a não compreensão ou uso de aspectos supra-segmentais da linguagem; fala entrecortada, pela ausência de conectivos; ou a falta de acesso a um sistema de monitoramento que forneça uma reaferentação constante para a fala.

Segundo Wilson (1993), uma criança com uma perda auditiva de leve a moderada pode ter dificuldade somente com o equilíbrio da ressonância oral-nasal, enquanto uma criança surda pode ter não só problemas de ressonância, como outros problemas envolvendo altura, intensidade, qualidade laríngea, velocidade e ritmo de fala. Uma criança surda normalmente tem dificuldade em manter velocidade e ritmo de fala adequados. Alguns falam com uma velocidade excessivamente baixa e padrões de ritmo inadequados.

Nas considerações de Hickok, Bellugi, Klima (1996) a velocidade do processamento das informações lingüísticas depende diretamente da audição. As línguas de sinais são mais lentas que as modalidades orais, pois o tempo decorrido entre a menor transição relevante lingüisticamente durante um sinal (cada mudança na forma das mãos) é de aproximadamente 200 milessegundos (ms), significativamente mais longa que o tempo decorrido na mais curta transição com a palavra falada (40 ms aproximadamente). 
Para Schiavetti et al.(1998), o uso da comunicação simultânea, ou bimodalismo (onde o sinal e a fala são usados simultaneamente), utilizada pelos professores e pais de surdos, faz com que estes sujeitos forneçam uma informação ao surdo numa velocidade de fala mais lenta que o habitual. Embora este seja um padrão diferente do usual, não natural, os autores consideram que a combinação dos modos manual e oral pode aumentar o desenvolvimento das habilidades comunicativas dos surdos e das crianças com impedimentos auditivos.

Segundo Ciocci e Baran (1998) crianças surdas usuárias da Comunicação Total utilizam uma única estratégia para reelaboração quando comparadas com crianças ouvintes da mesma faixa etária. As autoras atribuem este fato à forma como são conduzidas tanto as terapias fonoaudiológicas quanto a educação para surdos, que acaba privilegiando modelos comunicativos em detrimento da estimulação da criatividade lingüística e resolução de conflitos em situações de tensão comunicativa.

Nas considerações de Ramos (2000), a análise acústica de elementos prosódicos da fala enfatizando a freqüência fundamental e a duração durante a leitura de sentenças entre surdos, na faixa etária de 16 a 20 anos, identificou prolongamento dos sons da fala e intervalos de silêncio de segmentos entre as sílabas maiores em comparação com o grupo controle.

Partindo das colocações dos autores supra citados, que evidenciam a ligação entre a fluência e a linguagem, e o processo de aquisição de linguagem pelo surdo, pode-se considerar que é pertinente para a evolução dos estudos sobre a surdez, particularmente em sua interface com a fala e linguagem, que sejam desenvolvidas pesquisas sobre a fluência verbal dessa população. 
MÉTODO 


\section{SUJEITOS}

Neste estudo foram colhidas amostras de fala de 12 surdos profundos, perda neurossensorial congênita, bilíngües, ou seja, surdos oralizados em Português Brasileiro e usuários da Língua Brasileira de Sinais (LIBRAS), de ambos os sexos, adultos, sem distinção de raça, com escolaridade variando entre a $7^{a}$ série do ensino fundamental e superior completo, residentes na região metropolitana de São Paulo, freqüentadores de uma associação de surdos do município de São Paulo.

A captação dos sujeitos foi realizada na sede de uma associação de surdos, por sorteio aleatório. Num primeiro momento, a pesquisadora contatava os surdos freqüentadores da associação no local, verificando a disponibilidade pessoal para a participação na pesquisa. Foram necessários 11 meses para a completa coleta dos dados. Todos os sujeitos assinaram o Termo de Consentimento Pós-Informação (Anexo A).

Dos 18 sujeitos contatados, foram excluídos 3 deles por possuírem parentesco direto entre si, e 3 sujeitos que não apresentaram amostra de fala suficiente para análise acústico-perceptual.

Dos 12 sujeitos analisados na pesquisa, 8 eram do sexo masculino $(66,7 \%)$ e 4 do sexo feminino (33,3\%); com faixa etária variando de 18 à 39 anos e idade média de 27,83 anos; com grau de escolaridade fundamental $(16,67 \%$ dos indivíduos), médio (58,33\% dos indivíduos) e superior (25\% dos indivíduos) (Anexo B ).

Todos os sujeitos da pesquisa freqüentaram escola especial em alguma fase de sua vida escolar e utilizaram aparelhos de amplificação sonora individual. No momento da pesquisa, somente quatro sujeitos utilizavam os aparelhos de amplificação. Um sujeito não recebeu atendimento fonoaudiológico, porém passou por sala especial com enfoque oralista, onde recebeu treino auditivo, de fala e de 
leitura oro-facial com professora especializada(Anexo B). Quanto aos antecedentes familiares de surdez, $58,33 \%$ não o apresentavam enquanto $41,67 \%$ apresentavamno.

Para realizar o estudo comparativo inter-grupos, foram utilizados como referência os parâmetros de fluência obtidos por Andrade, Zackiewicz e Sassi (2000) com indivíduos adultos fluentes, sem queixa de qualquer distúrbio de fala e/ou audição, falantes do Português Brasileiro.

Realizou-se um estudo piloto para verificação da efetividade da metodologia adotada com 6 sujeitos surdos pré-lingüísticos, com idades entre 16 e 19 anos, de ambos os sexos, alunos da $8^{a}$ série do ensino fundamental de uma escola especial da região metropolitana de São Paulo, tendo sido utilizados 2 sujeitos do sexo masculino, com 17 e 19 anos de idade. Esse cuidado mostrou que o procedimento adotado foi pertinente e satisfatório (Anexo C). 


\section{MATERIAL}

A coleta das amostras de fala foi feita a partir da filmagem em filmadora portátil da marca JVC modelo GR-AX 230, fixada em tripé, colocada a aproximadamente um metro e meio de distância do sujeito. Foi utilizada fita de filmagem tipo VHS-C marca JVC, modelo TC - $30 \mathrm{EHG}$, com qualidade de gravação de som HI-FI.

$\mathrm{Na}$ contagem do tempo para análise da amostra de fala foi utilizado um cronômetro digital marca Cassio, modelo STOPWATCH HS-3, televisão e vídeocassete.

Também foram utilizados os seguintes materiais:

A) Termo de Consentimento Pós - Informação (Anexo A);

B) Protocolo de Anamnese (Anexo D);

C) Protocolo de Avaliação da Fluência, proposto por Andrade (2000b). Em decorrência das características e peculiaridades do grupo de pesquisa, para a análise da fala dos surdos, foi feita uma complementação do instrumento, tendo sido acrescentadas duas categorias: sinais e articulação sem som(Anexo E);

D) Figura, para eliciar o discurso (Anexo F). 


\section{PROCEDIMENTOS}

A pesquisa foi realizada na associação de surdos. Os sujeitos eram contatados pessoalmente e agendados, sendo recebidos pela própria pesquisadora.

Num primeiro momento os sujeitos receberam informações relativas aos objetivos da pesquisa e aos procedimentos éticos e metodológicos que seriam adotados. Em seguida foi aplicado o Protocolo de Anamnese, dirigido às questões de identificação pessoal, como tipo de escolaridade, antecedentes familiares de surdez, tempo de tratamento fonoaudiológico, uso ou não de aparelho de amplificação sonora individual.

Depois da anamnese, era iniciada a coleta da amostra de fala. Para obtenção das amostras de fala mostrou-se aos sujeitos uma figura, seguida da seguinte ordem: "Fale o que você acha dessa situação do modo natural para você, até que eu peça para você parar". Tal procedimento era mantido por tempo suficiente para obtenção da amostra de 200 sílabas de fala fluente. A pesquisadora ficava ao lado da filmadora durante a gravação. A pesquisadora interferia no discurso somente para garantir a obtenção da amostra de fala.

As amostras de fala foram transcritas no modo ortográfico e analisadas segundo os parâmetros do Protocolo de Avaliação da Fluência (Andrade, 2000b). A transcrição foi feita através da observação das fitas de vídeo. Inicialmente somente pela informação auditiva (para obtenção da amostra da produção oral), e posteriormente a coleta da informação visual (para a obtenção da amostra gestual). A junção destas duas informações constitui o corpus propriamente dito, ou seja, a amostra de fala pela produção multimodal. As gravações foram observadas quantas vezes se fizesse necessário para a obtenção da amostra multimodal (Anexo G).

A média de tempo utilizada para observação de cada fita e para a obtenção final da transcrição foi de 78,59 minutos. 
Após o levantamento do corpus foram elaboradas tabelas e gráficos que permitiram a submissão à análise estatística (teste estatístico de Wilcoxon, Siegel, 1975, e análise por comparação com intervalo de confiança, Glantz, 1997) e à posterior discussão dos resultados.

Para redução de possíveis interferências decorrentes da análise perceptual dos dados foi adotado o procedimento de submissão a juízes, como apontado por Curlee (1981), Moore e Perkins (1990), para potencialização da fidelidade e paridade dos resultados. As amostras de fala foram submetidas à avaliação de dois juízes, fonoaudiólogos com experiência no trabalho com surdos bilíngües. Esses profissionais receberam um treinamento especial sobre o Protocolo de Avaliação da Fluência (Andrade, 2000b). Foram selecionadas amostras de fala de 4 sujeitos surdos, escolhidos aleatoriamente entre os participantes da pesquisa. Os juízes receberam a instrução de assistir às fitas e anotar em folha própria quais as disfluências que o sujeito apresentava. Cada juiz assistiu a cada amostra de fala três vezes. Para verificação do índice de compatibilidade lingüística entre os juízes e a pesquisadora, os resultados foram submetidos ao teste estatístico de Kappa (Siegel, 1975). Houve concordância estatística significativa entre os juizes e entre os juizes e a pesquisadora, ou seja, os resultados foram similares entre os profissionais (Anexo H). 


\section{RESULTADOS}


Os resultados obtidos foram organizados em tabelas para a análise quantitativa. Foram considerados os aspectos relativos à expressão exclusivamente oral, e posteriormente comparados aos aspectos multimodais.

A análise quantitativa é apresentada na forma de tabelas gerais e específicas. A primeira parte da análise é composta por seis tabelas. Estas tabelas referem-se à comparação intra-grupo dos surdos em suas produções orais e multimodais, quanto aos aspectos de: velocidade de fala, tipologia das disfluências, e freqüência das rupturas. As tabelas que serviram de base para a análise apresentam-se anexas (Anexo I).

A segunda parte da análise é composta por três tabelas. Essas tabelas referem-se à comparação inter-grupos (indivíduos ouvintes fluentes e surdos), quanto aos aspectos de velocidade de fala, tipologia das disfluências, e freqüência das rupturas. As tabelas que serviram de base para essa análise apresentam-se anexas (Anexo I).

Também são apresentadas seis figuras para melhor visualização dos dados obtidos. São elas relativas à comparação geral intra-grupos e inter-grupos. 


\section{ANÁLISE INTRA-GRUPO}

Os resultados obtidos foram submetidos ao teste estatístico de Wilcoxon (Siegel, 1975) com nível de significância de 5\%. A tabela 1 apresenta os resultados gerais obtidos quanto à velocidade de fala, em palavras por minuto e sílabas por minuto, na produção oral e multimodal do surdo.

Tabela 1 - Produção oral e multimodal dos surdos quanto à velocidade de fala

\begin{tabular}{lcccc}
\hline & Estatística & Oral & Multimodal & P $\leq 0,05$ \\
\hline Palavras por minuto & Média & 49,73 & 59,34 & $0,0033^{*}$ \\
& Desvio-padrão & 13,35 & 14,50 & \\
Sílabas por minuto & Média & 97,70 & 120,37 & $0,0033^{*}$ \\
& Desvio-padrão & 25,44 & 29,89 & \\
\hline
\end{tabular}

O sinal $\left(^{*}\right)$ indica diferença estatística significante

Observa-se na tabela 1 que existiu diferença estatística significante entre as produções oral e multimodal quanto a este aspecto da fluência. A velocidade de fala, em palavras e sílabas por minuto, foi significativamente maior na produção multimodal que na produção oral.

As tabelas de 2 a 5 apresentam a análise dos resultados relativos à tipologia das disfluências. A tabela 2 compara a produção oral e multimodal dos surdos quanto à tipologia das disfluências comuns.

Tabela 2 - Produção oral e multimodal dos surdos quanto à tipologia das disfluências comuns.

\begin{tabular}{cccc}
\hline Estatística & Oral & Multimodal & $\mathrm{P} \leq 0,05$ \\
\hline Média & 15,00 & 9,33 & $0,0178^{*}$ \\
Desvio - padrão & 12,63 & 6,18 & \\
\hline
\end{tabular}

O sinal $\left(^{*}\right)$ indica diferença estatística significante 
$\mathrm{Na}$ tabela 2, observa-se diferença estatística significante entre a produção oral e a produção multimodal dos surdos. Como demonstrado na tabela, observouse que a produção oral apresentou maior média de ocorrências das disfluências comuns que a produção multimodal.

A tabela 3 compara a produção oral e multimodal dos surdos quanto às categorias de disfluências comuns.

Tabela 3 - Produção oral e multimodal dos surdos quanto às categorias de disfluências comuns

\begin{tabular}{ccccc}
\hline Tipologia & Estatística & Oral & Multimodal & P $\leq 0,05$ \\
\hline Hesitação & Média & 1,83 & 1,83 & 1,0000 \\
& Desvio-padrão & 3,27 & 3,27 & \\
Interjeição & Média & 2,00 & 2,25 & 0,4652 \\
& Desvio-padrão & 1,54 & 1,54 & 0,5839 \\
Revisão & Média & 0,58 & 0,75 & \\
& Desvio-padrão & 0,67 & 0,87 & $0,0051^{*}$ \\
Palavra Incompleta & Média & 8,58 & 1,67 & \\
& Desvio-padrão & 10,74 & 1,87 & 0,6547 \\
Repetição de & Média & 1,00 & 1,25 & 0,0679 \\
Palavra & Desvio-padrão & 1,21 & 2,05 & \\
Repetição de & Média & 0,75 & 1,17 & 0,3173 \\
Segmento & Desvio-padrão & 0,97 & 1,27 & \\
Repetição de Frase & Média & 0,25 & 0,42 & \\
& Desvio-padrão & 0,87 & 1,00 & \\
\hline
\end{tabular}

O sinal $\left(^{*}\right)$ indica diferença estatística significante

$\mathrm{Na}$ terceira tabela observa-se que nas amostras de fala obtidas foram identificados todos os tipos de disfluências comuns. As interjeições, as hesitações e as palavras incompletas foram identificadas tanto na produção oral quanto na multimodal. Na produção oral as palavras incompletas foram o tipo mais freqüente. $\mathrm{Na}$ produção multimodal as interjeições foram o tipo mais freqüente. Estes resultados mostraram diferença estatística significante somente quanto a de palavra incompleta, sendo esta mais freqüente na produção oral que na produção multimodal. 
A tabela 4 compara a produção oral e multimodal dos surdos quanto à tipologia das disfluências gagas.

Tabela 4 - Produção oral e multimodal dos surdos quanto à tipologia das disfluências gagas

\begin{tabular}{cccc}
\hline Estatística & Oral & Multimodal & $\mathrm{P} \leq 0,05$ \\
\hline Média & 23,75 & 4,92 & $0,0077^{*}$ \\
Desvio-padrão & 27,31 & 3,45 & \\
\hline O sinal $\left(^{*}\right)$ indica diferença estatística significante & &
\end{tabular}

$\mathrm{Na}$ tabela 4 verificou-se uma diferença estatística significante entre a produção oral e a multimodal, ou seja, uma maior freqüência de disfluências gagas na produção oral quando comparadas à multimodal.

A tabela 5 compara a produção oral e multimodal dos surdos quanto às categorias de disfluências gagas.

Tabela 5 - Produção oral e multimodal dos surdos quanto às categorias de disfluências gagas

\begin{tabular}{ccccc}
\hline Tipologia & Estatística & Oral & Multimodal & P $\leq 0,05$ \\
\hline Repetição de Sílaba & Média & 0,17 & 0,17 & 1,0000 \\
& Desvio-padrão & 0,39 & 0,39 & \\
Repetição de Som & Média & 0 & 0 & 0 \\
& Desvio-padrão & 0 & 0 & 1,0000 \\
Prolongamento & Média & 0,33 & 0,33 & 0 \\
& Desvio-padrão & 0,89 & 0,89 & \\
Bloqueio & Média & 0 & 0 & $0,0077^{\star}$ \\
& Desvio-padrão & 0 & 0 & \\
Pausa & Média & 23,17 & 4,33 & 1,0000 \\
& Desvio-padrão & 27,51 & 3,60 & \\
\hline \multirow{3}{*}{ Intrusão de Sons } & Média & 0,08 & 0,08 & \\
& Desvio-padrão & 0,29 & 0,29 & \\
\hline
\end{tabular}

O sinal $\left({ }^{*}\right)$ indica diferença estatística significante 
Nesta tabela foram colocados os resultados específicos dos tipos de disfluências gagas. Não ocorreram na amostra selecionada, nem para a produção oral nem para a produção multimodal, as tipologias de bloqueio e repetição de sons. Os tipos mais freqüentes foram as pausas, os prolongamentos e as repetições de sílabas, nesta ordem, tanto na produção oral quanto na multimodal. Houve diferença estatística significante somente nas pausas, sendo estas mais freqüentes na produção oral que na multimodal.

A tabela 6 apresenta os resultados gerais obtidos quanto à freqüência de rupturas, pela taxa de descontinuidade de fala e pela taxa de disfluências gagas, na produção oral e multimodal do surdo.

Tabela 6 - Produção oral e multimodal dos surdos quanto à freqüência de rupturas

\begin{tabular}{ccccc}
\hline & Estatística & Oral & Multimodal & $\mathrm{P} \leq 0,05$ \\
\hline \multirow{2}{*}{$\begin{array}{c}\text { Descontinuidade de } \\
\text { fala }\end{array}$} & Média & 19,56 & 5,99 & $0,003^{*}$ \\
& Desvio-padrão & 18,29 & 2,52 & $0,0033^{*}$ \\
Disfluências gagas & Média & 12,01 & 2,30 & 1,80 \\
& Desvio-padrão & 13,60 & 1 \\
\hline
\end{tabular}

O sinal $\left({ }^{*}\right)$ indica diferença estatística significante

Nos dados expostos na tabela 6 , observa-se uma taxa de descontinuidade de fala estatisticamente maior na produção oral quando comparada à produção multimodal. Tal diferença se repete quando comparamos os resultados da porcentagem de disfluências gagas, sendo estatisticamente maior na produção oral que na produção multimodal. 
Na figura 1, é apresentada a comparação intra-grupo quanto à velocidade da fala. Observam-se melhores resultados na produção multimodal tanto para palavras por minuto quanto para sílabas por minuto.

Figura 1 -Velocidade de fala - comparação intra-grupo

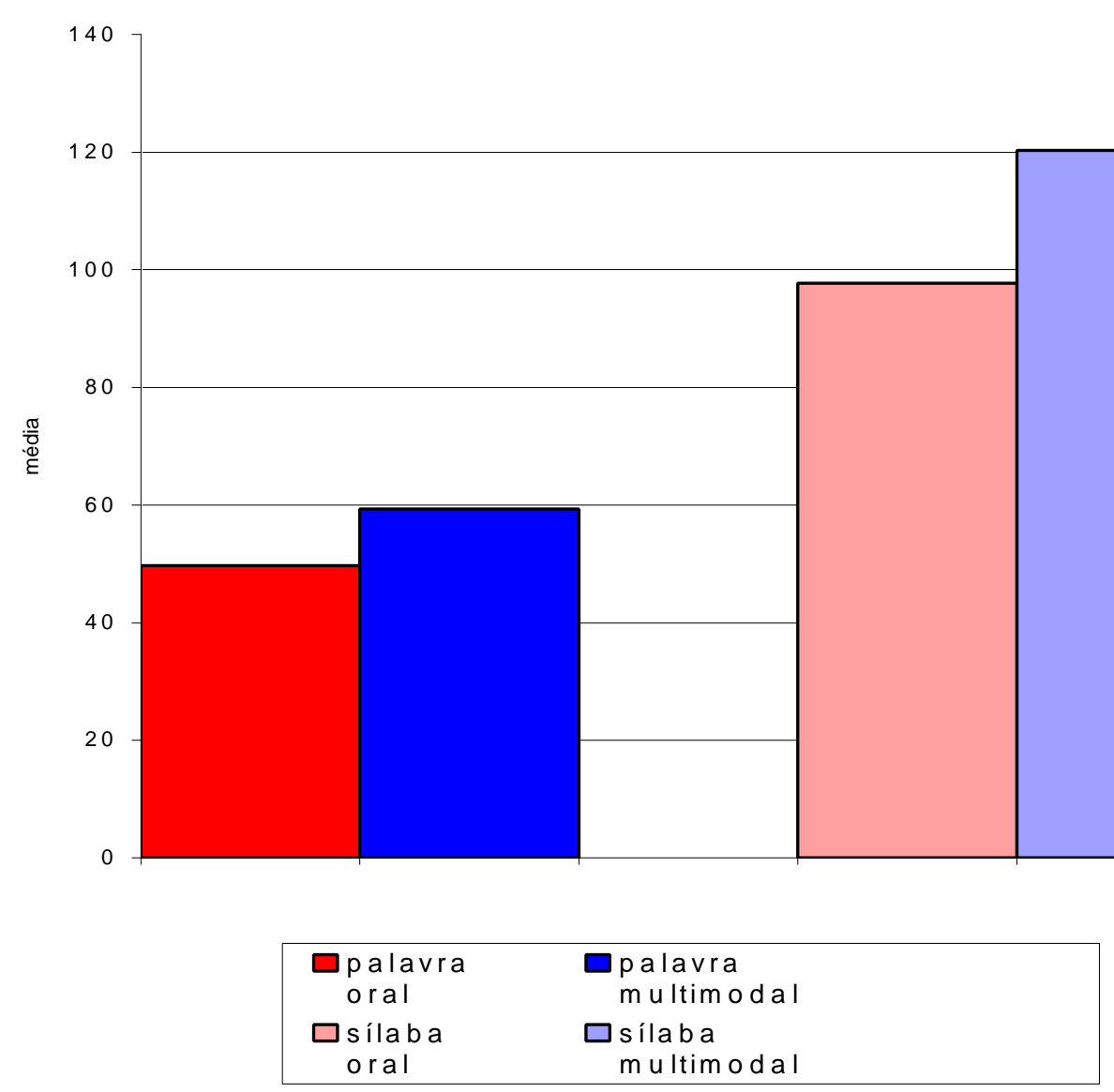

$\mathrm{Na}$ figura 2, é apresentada a comparação intra-grupo quanto à tipologia das disfluências. Observa-se maior freqüência de disfluências, comuns e gagas, na produção oral. 
Figura 2 - Tipologia das disfluências - comparação intra-grupo

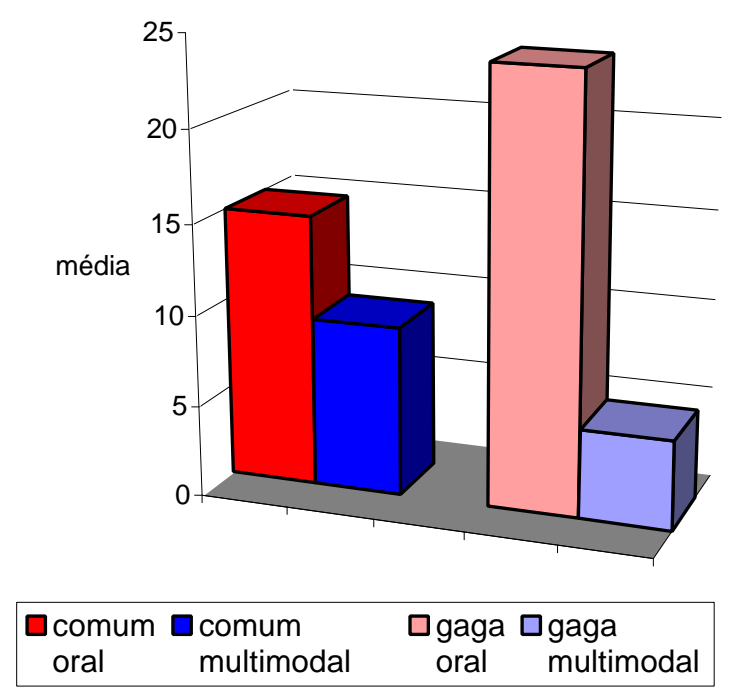

Na figura 3, é apresentada a comparação intra-grupo quanto à freqüência das rupturas. Observa-se maior freqüência de rupturas na produção oral tento para a descontinuidade de fala quanto para as disfluências gagas.

Figura 3 - Freqüência de rupturas da fala - comparação intra-grupo

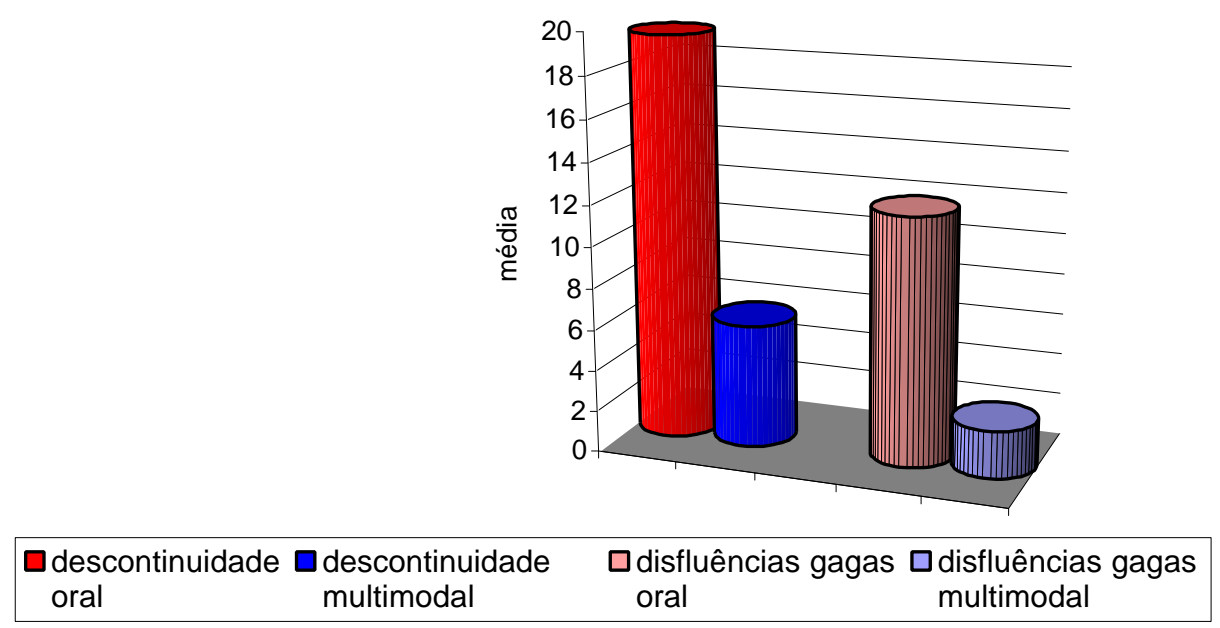




\section{ANÁLISE INTER-GRUPOS}

Nesta parte serão apresentadas as comparações entre o perfil da fluência do grupo de pesquisa (Gl) em seus aspectos oral e multimodal, e do grupo controle (GII). Os resultados foram analisados estatisticamente pela comparação por intervalo de confiança (Glantz,1997).

A tabela 7 compara a velocidade de fala em palavras e sílabas por minuto entre os grupos.

Tabela 7 - Comparação da velocidade da fala entre ouvintes fluentes e surdos

\begin{tabular}{lcccc}
\hline & Gl - Oral & Gl - Multimodal & Gll & $\begin{array}{c}\text { Intervalo de } \\
\text { Confiança }\end{array}$ \\
\hline Palavras por minuto & $49,73^{*}$ & $59,34^{*}$ & 128,79 & $117,3-140,3$ \\
Sílabas por minuto & $97,70^{*}$ & $120,37^{*}$ & 237,67 & $218,8-256,5$ \\
\hline
\end{tabular}

O sinal $\left(^{*}\right)$ indica que a média está fora do intervalo de confiança.

Observamos nesta tabela que a velocidade de fala em palavras por minuto e sílabas por minuto está significativamente abaixo dos limites parâmetro do grupo controle.

Tabela 8 - Comparação da tipologia das disfluências da fala entre ouvintes fluentes e surdos

\begin{tabular}{ccccc}
\hline & Gl - Oral & Gl - Multimodal & Gll & $\begin{array}{c}\text { Intervalo de } \\
\text { Confiança }\end{array}$ \\
\hline Comuns & 15,00 & $9,33^{*}$ & 16,3 & $11,8-20,6$ \\
Gagas & $23,75^{*}$ & $4,92^{*}$ & 0,9 & $0,1-2,0$ \\
\hline
\end{tabular}

O sinal * indica que a média está fora do intervalo de confiança.

A tabela 8 compara a tipologia das disfluências comuns e gagas entre os grupos. A primeira comparação refere-se à tipologia comum. Observa-se que as rupturas deste tipo para a produção oral encontram-se dentro do padrão esperado. 
Para a produção multimodal, os resultados encontram-se abaixo deste padrão, sendo esta diferença estatisticamente significante.

Quanto às rupturas gagas, observamos que os dados do Gl tanto para a produção oral quanto para a multimodal estão acima do padrão. Este resultado é estatisticamente significante para ambas as análises, ou seja, o Gl apresenta maior número de disfluências que o grupo controle.

A tabela 9 compara a freqüência de rupturas da fala entre os grupos.

Tabela 9 - Comparação da freqüência de rupturas da fala entre ouvintes fluentes e surdos.

\begin{tabular}{lcccc}
\hline & GI - Oral & GI - Multimodal & GII & $\begin{array}{c}\text { Intervalo de } \\
\text { confiança }\end{array}$ \\
\hline $\begin{array}{l}\text { Descontinuidade } \\
\text { de fala }\end{array}$ & $19,56^{*}$ & $5,99^{*}$ & 8,62 & $7,3-9,9$ \\
\begin{tabular}{l} 
Disfluências gagas \\
\hline
\end{tabular} & $12,01^{*}$ & $2,30^{*}$ & 0,47 & $0,2-0,7$ \\
\hline
\end{tabular}

O sinal * indica que a média está fora do intervalo de referência.

Observa-se pela tabela que os resultados da freqüência de rupturas da fala tanto para a descontinuidade da fala quanto para as disfluências gagas obtidos pelo Gl são significativamente maiores que o padrão, na produção oral. Quanto à produção multimodal, observa-se que os resultados obtidos para descontinuidade de fala estão significativamente abaixo do padrão e os resultados das disfluências gagas estão significativamente acima do padrão. 
A figura 4, refere-se à comparação quanto à velocidade de fala. Observam-se resultados significativamente menores tanto na produção oral quanto na produção multimodal do Gl, tanto para palavras quanto para sílabas por minuto quando comparados aos parâmetros do Gll.

Figura 4 - Velocidade de fala - comparação inter-grupos

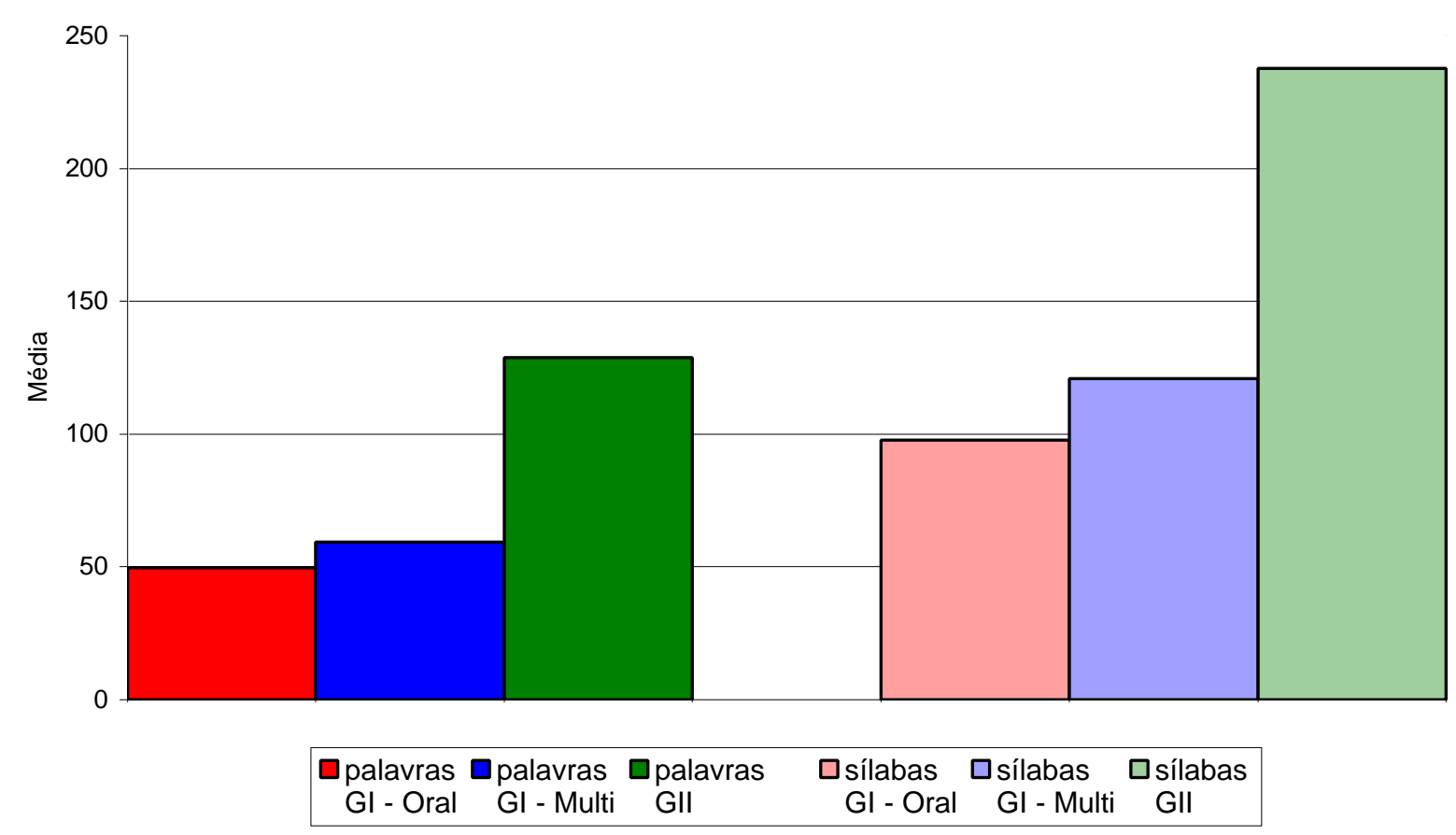

A figura 5, refere-se à comparação inter-grupos quanto à tipologia das disfluências. Observa-se que tanto o GI na produção oral quanto o Gll apresentam resultados semelhantes para a tipologia comum, e que o Gl na produção multimodal apresenta resultados significativamente inferiores aos demais grupos. Quanto à tipologia gaga, observa-se freqüência significativamente maior de disfluências na produção oral do GI, seguida da produção multimodal quando comparadas aos parâmetros do GII. 
Figura 5 - Tipologia das disfluências - comparação inter-grupos

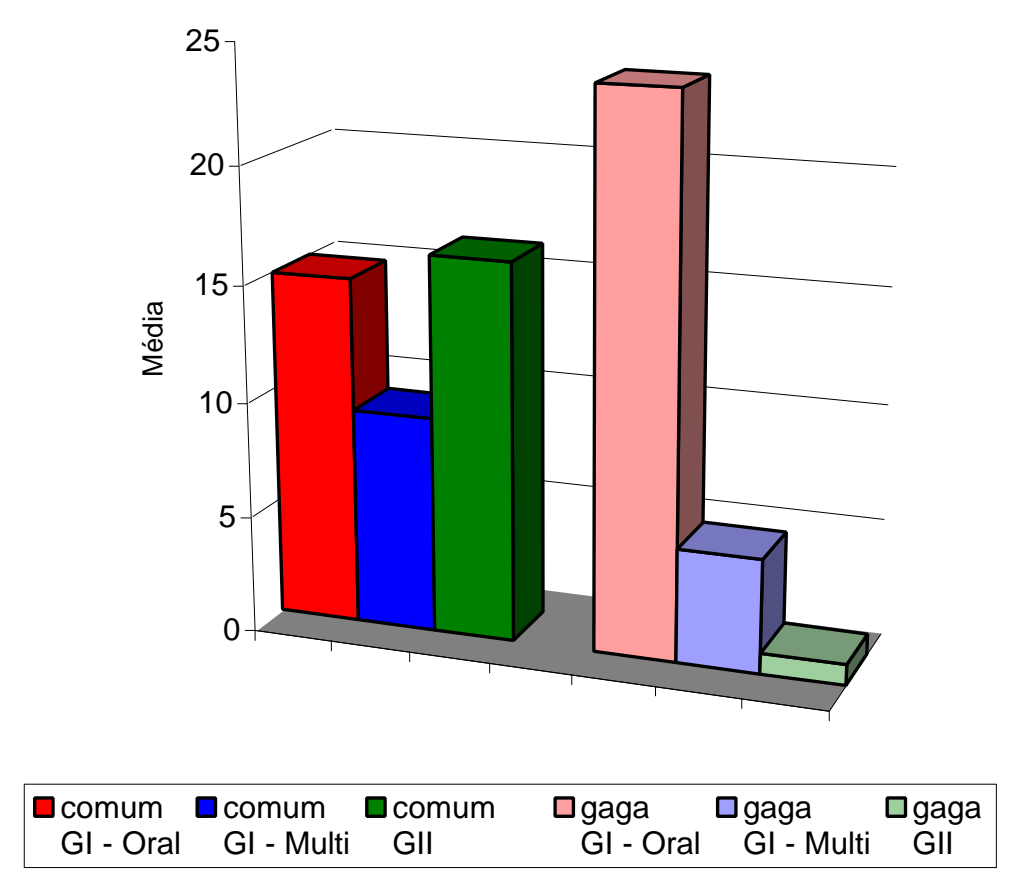

A figura 6 refere-se à comparação quanto à freqüência de rupturas da fala. Observam-se resultados significativamente maiores na produção oral do Gl quando comparados à multimodal e ao Gll, tanto para a descontinuidade de fala quanto para as disfluências gagas. Ou seja, a produção oral do Gl apresenta maiores taxas de ruptura quando comparada aos outros grupos analisados. 
Figura 6 - Freqüência de rupturas da fala - comparação inter-grupos

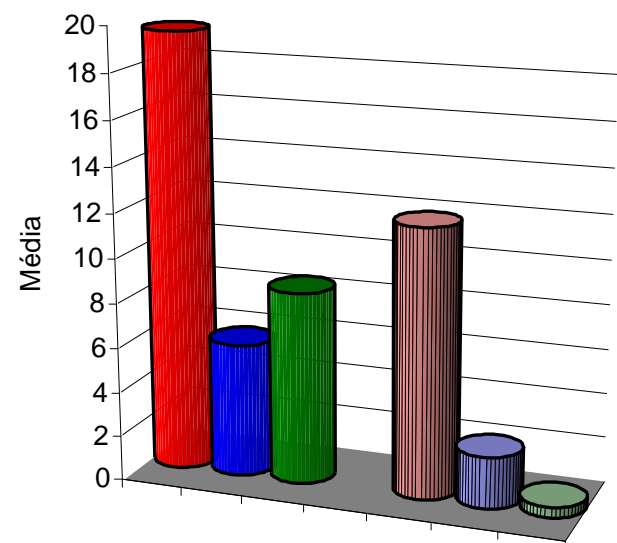

\begin{tabular}{ccc}
\hline descontinuidade & descontinuidade & descontinuidade \\
Gl - Oral & Gl-Multi & Gll
\end{tabular}

$\square$ disfluências gagas $\square$ disfluências gagas $\square$ disfluências gagas Gl - Oral

Gl - Multi

GII 


\section{DISCUSSÃO}


Os resultados obtidos nesta pesquisa, assim como o referencial teórico que forneceu o suporte para sua elaboração, serão discutidos segundo as hipóteses deste estudo.

Hipótese 1 - A velocidade de fala dos surdos é menor que a velocidade de fala dos ouvintes, tanto para o número de palavras por minuto quanto para o número de sílabas por minuto.

Esta hipótese foi confirmada. Neste estudo observou-se que os surdos possuem uma velocidade de fala significativamente menor que a dos ouvintes, independente do tipo de produção, oral ou multimodal. A velocidade de fala na condição multimodal é significativamente maior que na condição oral. Num estudo realizado por Fletcher e Daly (1976), o resultado obtido indica que para o grupo de surdos a velocidade de fala, em palavras por minuto, foi $45,09 \%$ menor que para 0 grupo ouvinte. No estudo aqui apresentado os resultados obtidos foram proporcionalmente inferiores. Para a avaliação oral foi $61,39 \%$ menor e para a avaliação multimodal foi $53,93 \%$ menor.

Essa redução comparativa da velocidade de fala do surdo poderia ser atribuída aos fatores de tempo no processamento da informação lingüística (Hickok, Bellugi, Klima, 1996), ao uso simultâneo de diferentes modalidades de linguagem (Schiavetti et al., 1998) e/ou ao domínio do código lingüístico (Prinz, 1989; Ciocci, Baran, 1998). 
Hipótese 2 - A tipologia das disfluências da fala dos surdos é diferente daquela encontrada nos ouvintes, tanto para as disfluências comuns quanto para as disfluências gagas.

Esta hipótese só não foi confirmada na produção oral, para a tipologia das disfluências comuns, onde os surdos apresentaram resultados semelhantes ao grupo ouvinte. Nas demais condições a hipótese foi confirmada.

Para a tipologia das disfluências comuns, na produção multimodal, os surdos apresentaram resultados inferiores ao do grupo ouvinte, ou seja, eles têm 57,23\% menos disfluências. Não foi encontrada na literatura pesquisada qualquer referência de suporte para este resultado. Pode-se inferir que isso ocorra pelo uso simultâneo de duas línguas gramaticalmente distintas, o Português Brasileiro (áudio-oral) e a Língua Brasileira de Sinais (visual-espacial). Na visão pessoal da pesquisadora, com base na literatura consultada, sendo a Língua de Sinais uma língua natural com estrutura gramatical própria, deve apresentar marcadores lingüísticos discursivos e disfluências tidas como comuns que necessitam de descrição apropriada.

Para a tipologia das disfluências gagas, na produção oral, os surdos apresentaram 26,4 vezes mais disfluências gagas que o grupo ouvinte.

Para a tipologia das disfluências gagas, na produção multimodal, os surdos apresentaram 5,5 vezes mais rupturas que o grupo ouvinte. Este resultado é semelhante aos apresentados por Fletcher e Daly (1976), Gold (1980) e Ramos (2000), onde os autores consideram que a fala dos surdos pode ser caracterizada por pausas excessivas, intrusão e prolongamento de sons. 
Hipótese 3 - A freqüência de rupturas na fala dos surdos é maior que aquela encontrada na fala dos ouvintes.

Esta hipótese só não foi confirmada para o grupo de surdos na produção multimodal quanto à porcentagem de descontinuidade de fala, que é 69,48\% inferior à encontrada no grupo controle. Nas demais condições a hipótese foi confirmada.

A freqüência de rupturas gagas na produção multimodal, para os surdos, é 4,9 vezes maior que para o grupo controle. Na produção oral esta freqüência é 2,8 vezes superior. Quanto à porcentagem de disfluências gagas esta freqüência é 25,5 vezes superior.

Também esses resultados foram compatíveis com a literatura pesquisada e já destacada (Fletcher, Daly ,1976; Gold, 1980; Ramos, 2000), ou seja, mesmo sendo uma forma "mista" de comunicação (oral e sinal) em termos de fluência do discurso, os surdos não apresentam um fluxo suave e contínuo de produção de fala.

Hipótese 4 - A fluência da fala dos surdos na produção multimodal é semelhante à fluência da fala dos ouvintes.

Esta hipótese não foi confirmada. Apesar dos resultados obtidos na produção multimodal terem sido estatisticamente superiores aos obtidos na produção oral, o perfil da fluência deste grupo (velocidade de fala; tipologia das rupturas e freqüência de rupturas) tem características particulares. A velocidade de fala é lentificada em quase $50 \%$ do tempo quando comparada à dispendida pelos ouvintes. A tipologia das disfluências é diferente da obtida para o grupo ouvinte, ou seja, a ruptura mais freqüente, pausas longas, não é encontrada no grupo ouvinte em proporção semelhante. 
CONSIDERAÇÕES FINAIS 
Como já é sabido, a deficiência auditiva traz desvantagens em relação ao acesso às informações, com conseqüências sociais de exclusão e como obstáculo à realização das expectativas do próprio surdo e de sua família. A deficiência auditiva limita as oportunidades ocupacionais e ainda muitas vezes, até para a família do surdo e para a sociedade em geral, o surdo é visto não como um portador de um déficit sensorial e sim como incapaz e incompetente para gerenciar a própria vida.

Pelos resultados obtidos nesse estudo, a fluência da fala dos surdos é mais lenta que a dos ouvintes, devido às seqüelas que a privação sensorial da audição traz para o processamento das informações lingüísticas por via auditiva. Tentar suprir esse déficit pela introdução precoce da língua de sinais, por um lado é um caminho mais natural para a aprendizagem, por outro lado, conforme os resultados, a oralidade não pode ser suprimida. Até onde este estudo permite inferir, o que parece mais efetivo, é que haja uma associação das duas modalidades, mesmo sabendo que em termos de fluência ainda não será atingido um parâmetro semelhante ao do ouvinte.

Pode-se dizer que para os sujeitos deste estudo a língua de sinais reduz a incapacidade comunicativa gerada pela surdez, quando usada com interlocutores privilegiados, que conheçam a língua de sinais, ou que estejam dispostos a conhecê-la. Entretanto não reduz a desvantagem comunicativa gerada pela surdez, uma vez que o surdo acaba utilizando uma língua minoritária, restrita a grupos bastante específicos, do mesmo modo que outros sujeitos bilíngües, sejam estrangeiros ou povos indígenas.

Portanto negar a língua de sinais não é adequado. A língua de sinais deve ser considerada e respeitada. Porém, negar o acesso à oralidade também não se mostra adequado, visto que em uma sociedade cada vez mais competitiva, que busca igualar todos sem lhes dar as mesmas oportunidades, contribuiria para manter um ciclo de discriminação. 
A modalidade oral é a natural de qualquer falante de qualquer língua e portanto deve ser também acessível aos surdos. Devemos questionar e refletir sobre a forma excludente e elitista como este acesso é fornecido. Devemos reavaliar posturas e políticas educacionais e de saúde que permitam o acesso universal aos serviços e atendimentos de qualidade, diferenciados para cada indivíduo. Em paralelo a esta atuação mais ampla e de alcance populacional, devemos também refletir sobre nossas práticas diárias com esta população. As queixas dos fonoaudiólogos e dos surdos são muitas. Os fonoaudiólogos reclamam da "lentidão" do surdo para assimilar e utilizar os conceitos ensinados. Os surdos reclamam da forma como estes conceitos são ensinados.

A pesquisa aqui apresentada representa uma pequena contribuição para a área do conhecimento fonoaudiológico que é a audiologia educacional. Muitas questões permanecem sem resposta, tais como: A fluência verbal do surdo analisada através da produção multimodal é menor que a dos ouvintes fluentes, mas seria semelhante à de outros sujeitos bilíngües? A lesão que provoca a deficiência sensorial característica da surdez impõe limites ou características próprias para a fluência dos surdos oralizados? As línguas de sinais apresentariam elementos de disfluência comuns e "gagas"? Uma proposta de trabalho fonoaudiológico, baseada em aspectos da fluência da fala promoveria este aspecto? Sugerindo que existe um campo vasto a ser pesquisado. 
BIBLIOGRAFIA 
ANDRADE, C.R.F. de . Fonoaudiologia preventiva: teoria e vocabulário técnico científico. São Paulo, Lovise, 1996 . Programa fonoaudiológico de promoção da fluência para Adultos; aplicações diferenciadas. (Tese de Livre Docência. Faculdade de Medicina da Universidade de São Paulo). 1999. . Processamento da fala: aspectos da fluência.

Pró-Fono, 12 (1):69-71, 2000 (a). . Protocolo para avaliação da fluência da fala. Pró-Fono, 12 (2):131-134, 2000 (b).

ANDRADE, C.R.F. de; ZACKIEWICZ, D.V.; SASSI, F.C.. Aspects of fluent speech in normal brazilian adults (submetido 2000)

BALIEIRO, C.R.; PUPO, A.C. Deficiência auditiva: ênfase na reabilitação precoce. Revista da Sociedade Brasileira de Fonoaudiologia, 1(2): 14-17, 1997.

BEHARES, L.E.. Implicações neuropsicológicas dos recentes descobrimentos na aquisição de linguagem pela criança surda. In: MOURA, M.C.; LODI, A.C.B.; PEREIRA, M.C. do C. (ed.). Língua de sinais e educação do surdo.

Série Neuropsicologia, v.3. São Paulo, Tec Art,: 41-56, 1993. 
BEHARES, L.E.; PELUSO, L.. A língua materna dos surdos: reflexões sobre o sentido da aquisição da linguagem pelos surdos. Espaço, 6(1): 40-48, 1997.

BEHLAU, M.S.; RUSSO, I.C.P.. Percepção da fala: análise acústica do Português Brasileiro. São Paulo, Lovise, 1993.

BEVILACQUA, M.C.; FORMIGONI, G.M.P. . Audiologia educacional: uma opção terapêutica para a criança deficiente auditiva. $2^{\mathrm{a}}$ ed. rev., Carapicuíba, Pró-Fono, 1998.

BLOCK, S.; KILLEN, D. . Speech rates of Australian English-speaking children and adults. Australian Journal of Communication, 24 (1): 39-44, 1996.

BOTELHO, P. . Segredos e silêncios na educação dos surdos. Belo Horizonte, Autêntica, 1998.

BRITO, L.F.. Por uma gramática de língua de sinais. Rio de Janeiro, Tempo Brasileiro, 1995.

BUENO, J.G.S.. Surdez, linguagem e cultura. Cadernos Cedes, 46:41-55, 1998.

CAMPBELL, J.H.; HILL, D.G.. Systematic Disfluency Analysis. Northwestern University, 1994. 
CICCONE, M.. Comunicação total: introdução, estratégia, a pessoa surda. Rio de Janeiro, Cultura Médica, 1996.

CIOCCI, S.R.; BARAN, J. A.. The use of conversational repair strategies by children who are deaf. American Annals of the Deaf, 143 (3): 235-245, 1998.

COUTINHO, E.C.L.. Aparelho de amplificação sonora individual: aspectos básicos. In: LICHTIG, I.; CARVALLO, R.M.M.. Audição: abordagens atuais. Carapicuíba, Pró-Fono, :305-337, 1997.

CURLEE, R.F.. Observer agreement on disfluency and stuttering. Journal of Speech and Hearing Research, 24:595-600, 1981.

DAGENAIS, P.A.; CRITZ-CROSBY, P.; FLETCHER, S.G.; MC CUTCHEON, M.J.. Comparing abilities of children with profound hearing impairments to learn consonants using electropalatography or traditional aural-oral techniques. Journal of Speech, Language, and Hearing Research, 37: 687-699, 1994.

FÁVERO, L.L.; ANDRADE, M.L.C.V.O.; AQUINO, Z.G.O.. Oralidade e escrita: Perspectivas para o ensino de língua materna. $2^{3}$ ed. , São Paulo, Cortez, 2000.

FERNANDES, E.. O som, este ilustre desconhecido. In: SKLIAR, C. (org.). Atualidade da educação bilíngüe para surdos: interfaces entre pedagogia e lingüística. Vol.2, Porto Alegre, Mediação, : 95-102, 1999. 
FLETCHER, S.G.; DALY, D.A.. Nasalance in utterances of hearing-impaired speakers. Journal of Communication Disorders, 37(1):63-73, 1976.

FÓRUM DE DEBATES: CRIANÇA E AUDIÇÃO.. Resolução no. 1 - abril de 1995. Pró-Fono, 7 (2): 75-78, 1995.

GARGALLO, I.S.. Análisis contrastivo, análisis de errores e interlengua en el marco de la lingüística contrastiva. Madrid, Editorial Síntesis, 1993.

GHISI, E.M.. Dinâmica institucional na operacionalização da educação bilíngüe do surdo no Uruguai. In: MOURA, M.C.; LODI, A.C.B.; PEREIRA, M.C. do C. (ed.). Língua de sinais e educação do surdo. Série de Neuropsicologia, v.3, São Paulo, Tec Art,: 94-104, 1993.

GLANTZ,S. Primer of biostatistics. $4^{a}$ ed., New York, McGraw-Hill, 1997.

GOLD, T.. Speech production in hearing-impaired children. Journal of Communication Disorders. 13(6): 397-418, 1980.

GOLDFELD, M.. A criança surda: linguagem e cognição numa perspectiva sócio-interacionista. São Paulo, Plexus, 1997.

GOSS, B.. The Psycology of human communication. Illinois, Waveland, 1989. 
HICKOK, G.; BELLUGI, U. ; KLIMA, E. S.. The neurobiology of sign language and its implications for the neural basis of language. Nature, 381(6584): 699-702, 1996.

HOWELL, P.; AU-YEUNG, J.; SACKIN, S.. Exchange of stuttering from function words to content words with age. Journal of Speech, Language, and Hearing Research, 42(2): 345-54, 1999.

HUBBARD, C.P.. Stuttering, stressed syllables, and word onsets. Journal of Speech, Language, and Hearing Research, 41,:802-808, 1998.

IÓRIO, M.C.M.. O processo de seleção e de adaptação de próteses auditivas: seleção das características eletroacústicas. In: LICHTIG, I.; CARVALLO, R.M.M.(org.). Audição: abordagens atuais. Carapicuíba, Pró-Fono, :339-363, 1997.

KYLE, J.G.. O ambiente bilíngüe: alguns comentários sobre o desenvolvimento do bilingüismo para os surdos. In: SKLIAR, C.(org.). Atualidade da educação bilíngüe para surdos: processos e projetos pedagógicos. vol.1, Porto Alegre, Mediação, :15-26, 1999.

KOZLOWSKI, L.. A percepção auditiva e visual da fala. Rio de Janeiro, Revinter, 1997.

LACERDA, C.B.F. de. Um pouco da história das diferentes abordagens na educação 
dos surdos. Cadernos Cedes, 46: 68-80, 1998.

LEEPER, L.H.; CUKATTA, R.. Speech fluency: effect of age, gender and context. Folia Phoniatr Logop, 47: 1-14, 1995.

LICHITIG, I.; HERMANN, R.; MACHADO, L.P.; QUEIROZ, C.N.. Recursos de feedback visual na reabilitação oral do deficiente auditivo. In: LICHTIG, I.; CARVALLO, R.M.M.(org.). Audição: abordagens atuais. Carapicuíba, Pró-Fono, :269-287, 1997.

LOPES, M.C.. A mediação material e signica no processo de integração de crianças surdas. In: SKLIAR, C. (org.). Educação e exclusão: abordagens sócioantropológicas em educação especial. Cadernos de Autoria, 2, Porto Alegre, Mediação, :81-104, 1997.

LUJÁN, M.A.. As crianças surdas adquirem sua língua. In: MOURA, M.C.; LODI, A.C.B.; PEREIRA, M.C. do C. (ed.). Língua de sinais e educação do surdo. Série de Neuropsicologia, v.3. São Paulo, Tec Art, :129-136, 1993.

MACLAY, H.; OSGOOD, C.E.. Hesitation phenomena in spontaneous english Speech. Word, 15: 19-44, 1959.

MAHER, T.M.. O dizer do sujeito bilíngüe: aportes da sóciolíngüística. Anais do Seminário: desafios e possibilidades na educação bilíngüe para surdos. Rio de Janeiro, INES,: 20-26, 1997. 
MARCUSCHI, L.A.. Marcadores conversacionais no português brasileiro: formas, posições e funções. In: Português culto falado no Brasil. Campinas, Editora da UNICAMP, 1989, p.281-321.

MARGALL, S.A.C.. Comunicação total versus método oral: identificação de sons do Português brasileiro produzido por deficientes auditivos. (Tese de Doutorado Escola Paulista de Medicina), 1994.

MASSONE, M.I.. O lingüista ouvinte frente a uma comunidade surda e ágrafa: metodologia da investigação. In: MOURA, M.C.; LODI, A.C.B.; PEREIRA, M.C. do C. (ed.). Língua de sinais e educação do surdo. Série de Neuropsicologia, v. 3. São Paulo, Tec Art, :72-93, 1993.

MELINE, T.. Description of phonological patterns for nineteen elementary-age children with hearing losses. Perceptual and Motor Skills, 85:643-653, 1997.

MENEGOTTO, I.H.; ALMEIDA, K. de; IÓRIO, M.C.M.. Características físicas e eletroacústicas das próteses auditivas. In: ALMEIDA, K. de; IÓRIO, M.C.M.. Próteses Auditivas: fundamentos teóricos e aplicações clínicas. São Paulo, Lovise,.:47-74, 1996

MILLER, P.. The effect of communication mode on the development of phonemic awarwness in prelingually deaf students. Journal of Speech, Language, and Hearing Research, 40,:1151-63, 1997. 
MOORE, S.E.; PERKINS, W.H.. Validity and reliability of judgments of authentic and simulated stuttering. Journal of Speech and Hearing Disorders, 55, :383-91, 1990.

MOURA, M.C.. A língua de sinais na educação da criança surda. In: MOURA, M.C.; LODI, A.C.B.; PEREIRA, M.C. do C. (ed.). Língua de sinais e educação do surdo. Série de Neuropsicologia, v.3. São Paulo, Tec Art, :1-4, 1993.

NORTHERN, J.L.; DOWNS, M.P.. Audição em crianças. $3^{\text {a }}$. ed., São Paulo, Manole, 1989.

PAIS, C.T.. Ensaios semiótico-lingüísticos. Petrópolis, Vozes, 1976. . Elementos de fonologia estrutural. In: PAIS, C.T. Manual de lingüística. $2^{a}$. ed., São Paulo, Global, :9-80, 1986.

PERKINS, W.H.; KENT, R.D.; CURLEE, R.I.. A teory of neuropsycholinguistic function in stuttering. Journal of Speech and Hearing Research, 34,: 734-52, 1991.

PETERS, A.. The units of language acquisition. New York, Cambridge University Press, 1983.

PRINS, D.; MAIN, V.; WAMPLER, S.. Lexicalization in adults who stutter. Journal of Speech, Language, and Hearing Research, 40: 373-84, 1997. 
PRINZ, P.M.. Desenvolvimento da comunicação e linguagem, avaliação e conduta em indivíduos com deficiência auditiva. In: KATZ, J. Tratado de audiologia clínica. $3^{a}$. ed., São Paulo, Manole, :798-825, 1989.

QUADROS, R.M.. Educação de surdos: a aquisição da linguagem. Porto Alegre, Artes Médicas, 1997.

RAMOS,S.M.. Análise prosódica da fala do deficiente auditivo: parâmetros de Duração e freqüência fundamental. (Dissertação de mestrado - Pontifícia Universidade Católica de São Paulo), 2000.

SAUSSURE, F.. Curso de Lingüística Geral. $4^{\mathrm{a}}$ ed. , São Paulo, Cultrix, 1972.

SCARPA, E.M.. Sobre o sujeito fluente. Caderno de Estudos Lingüísticos, 29: 163-184, 1995.

SCHIAVETTI, N.; WHITEHEAD, R.L.; WHITEHEAD, B.; METZ, D.E.. Effect of fingerspelling task on temporal characteristics and perceived naturalness of speech in simultaneous communication. Journal o Speech, Language, and Hearing Research, 41,:5-17, 1998.

SCHOCHAT, E.. Fonética, Fonologia e Fonoaudiologia: contribuição aos estudos dos distúrbios da fala e da percepção auditiva. Acta Semiótica et Linguistica, ed. Plêiade, 6, :167-178, 1996. 
SIEGEL, S.. Estatística não paramétrica: para as ciências do comportamento. São Paulo, McGraw-Hill, 1975.

SILVERMAN, S.W.; RATNER, N.B.. Syntactic complexity, fluency, and accuracy of sentence imitation in adolescents. Journal of Speech, Language, and Hearing Research, 40,: 95-106, 1997.

SKLIAR, C.. Uma perspectiva sócio-histórica sobre a psicologia e a educação dos surdos. In: SKLIAR, C.. Educação e exclusão: abordagens sócio-antropológicas em educação especial. Cadernos de Autoria, no. 2.,Porto Alegre, Mediação, :105-53, 1997.

STARKWEATHER, C.W.; GIVENS-AKERMAN, J.. Stuttering. Austin, Pro-Ed, 1997.

STEWART, D.A.. Pesquisa sobre o uso de sinais na educação de crianças surdas. In: MOURA, M.C.; LODI, A.C.B.; PEREIRA, M.C. do C.(ed.). Língua de sinais e educação do surdo. Série de Neuropsicologia, v.3.,São Paulo, Tec Art, : 94-104, 1993.

STOKOE, W.C.. Sign and speech. Signal Language studies, 93:357-72, 1996

WILSON, K.. Problemas de voz em crianças deficientes auditivas. In: Problemas de voz em crianças. $3^{a}$ ed. , São Paulo, Manole, : 301-327, 1993. 
YANTES, P.A.. Teste de condução aérea do tom puro. In: KATZ, J.(ed.). Tratado de audiologia clínica. $3^{\mathrm{a}}$ ed., São Paulo, Manole, :153-169, 1989. 


\section{ANEXOS}




\section{ANEXO A - TERMO DE CONSENTIMENTO PÓS-INFORMAÇÃO}

(Obrigatório para pesquisas científicas em seres humanos - Resolução do Conselho Nacional de Saúde no 196 (10/10/96)

1 - Dados de Identificação do Paciente ou Responsável Legal

- Nome: Sexo:

- D.N.:

- Endereço completo:

- Tel. p/ contato:

- Assinatura do responsável Legal:

- Natureza (grau de parentesco):

- Documento de Identidade: Órgão de Expedição:

\section{2 - Dados sobre a Pesquisa Científica}

Título: Análise da fluência verbal de surdos oralizados em Português Brasileiro e usuários de Língua Brasileira de Sinais

Pesquisador: Fonoaudióloga Susana Francischetti Garcia

Inscrição no Conselho Regional de Fonoaudiologia: CRFa 6372/SP

Natureza da Pesquisa: pesquisa de avaliação dos aspectos da fluência verbal de fala obtida através de filmagem

Avaliação do risco da pesquisa: sem risco ou de baixo risco

Procedimento de pesquisa: uma sessão para coleta de amostra de fala contendo um mínimo de 200 sílabas a partir de 2 figuras para elicitar estímulo visual

Desconforto e riscos esperados: nenhum

Benefícios que poderão ser obtidos: possibilidade de melhoria das técnicas de trabalho fonoaudiológico para a promoção da fluência verbal

Procedimentos alternativos que possam ser vantajosos: possibilidade de melhoria das técnicas de trabalho fonoaudiológico para a promoção da fluência verbal

Compromisso de fornecer quaisquer esclarecimentos solicitados: sim

Possibilidade de retirada do consentimento assim que solicitado: sim

Compromisso sobre a segurança de não identificação e sigilo sobre as informações obtidas: sim

Compromisso de atualizar informações: sim 
Disponibilidade de assistência fonoaudiológica: sim

3 - Observações:

4- Consentimento pós - esclarecido:

Declaro que, após ter sido convenientemente esclarecido pelo pesquisador, conforme registro anterior, consinto em participar, na qualidade de paciente, do referido projeto de pesquisa.

DATA:

Assinatura do paciente

Assinatura do pesquisador ou responsável

$1^{1}$

${ }^{1}$ Este termo deverá ter 2 vias, uma em poder do paciente outro anexado ao prontuário. 
ANEXO B - TABELA DE IDENTIFICAÇÃO DOS SUJEITOS

\begin{tabular}{|c|c|c|c|c|c|c|c|c|c|}
\hline Sujeito & $\begin{array}{c}\text { Identifica- } \\
\text { ção }\end{array}$ & Sexo & Idade & Raça & $\begin{array}{l}\text { Escolari- } \\
\text { dade }\end{array}$ & $\begin{array}{l}\text { Escola } \\
\text { Especial }\end{array}$ & A.A.S.I & Fono & $\begin{array}{l}\text { Antece- } \\
\text { dentes } \\
\text { familiares }\end{array}$ \\
\hline 1 & S.L.G.N. & fem. & 31 & Branca & Superior & Sim & Sim & $\operatorname{Sim}(O)$ & Sim \\
\hline 2 & L.M.R.V. & masc. & 19 & Branca & Médio & Sim & $\operatorname{Sim}(A)$ & $\operatorname{Sim}(O S)$ & Não \\
\hline 3 & E. S. & masc. & 38 & Branca & Médio & Sim & Sim & $\operatorname{Sim}(O)$ & Sim \\
\hline 4 & M.H.H. & fem. & 31 & Amarela & Superior & Sim & Sim & $\operatorname{Sim}(O)$ & Sim \\
\hline 5 & E.B.A. & fem. & 34 & Branca & Médio & Sim & Sim & $\operatorname{Sim}(O)$ & Não \\
\hline 6 & S.A.S. & masc. & 34 & Branca & Médio & Sim & $\operatorname{Sim}(A)$ & $\operatorname{Sim}(0)$ & Não \\
\hline 7 & F.G. & masc. & 30 & Branca & Médio & Sim & Sim & $\operatorname{Sim}(O)$ & Não \\
\hline 8 & G.A.Q. & masc. & 23 & Branca & Superior & Sim & $\operatorname{Sim}(A)$ & $\operatorname{Sim}(O S)$ & Sim \\
\hline 9 & C.P.O. & masc. & 18 & Branca & Médio & Sim & Sim & $\operatorname{Sim}(O)$ & Não \\
\hline 10 & S.S.P. & masc. & 23 & Negra & $\begin{array}{c}\text { Fundamen- } \\
\text { tal }\end{array}$ & Sim & Sim & $\operatorname{Sim}(O)$ & Não \\
\hline 11 & N.G. & fem. & 30 & Branca & $\begin{array}{c}\text { Fundamen- } \\
\text { tal }\end{array}$ & Sim & $\operatorname{Sim}(A)$ & Não & Sim \\
\hline 12 & M.F.A. & masc. & 23 & Branca & Médio & Sim & Sim & $\begin{array}{c}\operatorname{Sim}(\mathrm{O} / \\
\mathrm{CT})\end{array}$ & Não \\
\hline
\end{tabular}

fem. = sexo feminino; masc. $=$ sexo masculino; $(A)=$ uso atual de $A A S I ;(O)=$ terapia oralista sem referência da linha terapêutica; $(\mathrm{OS})=$ terapia oralista/ método SUVAG; $(C T)=$ comunicação total 


\section{ANEXO C - ESTUDO PILOTO}

SUJEITO - 1C

NOME: W.B.M.

SEXO: masculino

IDADE: 19 anos

ESCOLARIDADE: $8^{a}$ série do ensino fundamental

\section{Transcrição da amostra}

\section{1.a. Transcrição padrão}

Casa favela né homi itá sentado caixa u chão itá sujo num tem casa rico só pobre homem tá sozinho // tá sozinho// mais u menu? Novi dei// eu acho não // homem memo numca trabalha num tem o mininu vai pra rua fica pobre rouba droga // imãu? Acho que não // tá dentro // casa // acho não // a casa dentro tá sujo nu tem televisão só rua fica pobre num tem brinca // tem fomi ele mulé vai junto feira sabe? Feira pega come num tem dinheru comprá // pessoa ajuda dá // esse? Não // outra pessoa? Vi // longe São Paulo vi // tem // eu vi pouco

\section{1.b. Texto expresso multimodal}

Casa favela. Homi itá sentado. U chão itá sujo, num tem casa rico, só pobre. Homem tá sozinho. Tá sozinho. Mais u menu? Novi, dei. Eu acho não. Tá dentro. Casa. Acho não. A casa dentro tá sujo. Num tem televisão. Só rua fica. Pobre, num tem brinca. Tem fome. Ele, mulé vai junto feira. Pega come. Num tem dinheiro comprá. Pessoa ajuda, dá. Esse? Não. Outra pessoa? Vi. Longe. São Paulo vi. Tem. Eu vi pouco. 


\section{Análise - produção oral}

2.1. Tipologia das disfluências

\begin{tabular}{|l|c|l|c|}
\hline Disfluências comuns & \multicolumn{2}{l|}{ Disfluências gagas } \\
\hline Hesitação & 0 & Repetição sílaba & 0 \\
\hline Interjeição & 2 & Repetição som & 0 \\
\hline Revisão & 0 & Prolongamento & 0 \\
\hline Palavra incompleta & 0 & Bloqueio & 0 \\
\hline Repetição palavra & 1 & Pausa & 1 \\
\hline Repetição Segmento & 0 & Intrusão som & 0 \\
\hline Repetição frase & 0 & & 1 \\
\hline TOTAL & 3 & TOTAL & \\
\hline
\end{tabular}

2.2. Velocidade de fala

\begin{tabular}{|l|l|}
\hline Fluxo de palavras por minuto & Fluxo de sílabas por minuto \\
\hline $97 / 2,42=$ & $195 / 2,42=$ \\
\hline
\end{tabular}

2.3. Freqüência de rupturas da fala

\begin{tabular}{|l|l|}
\hline \% de descontinuidade de fala & \% de disfluências gagas \\
\hline $4 / 195=$ & $1 / 195=$ \\
\hline $2,05 \%$ & $0,50 \%$ \\
\hline
\end{tabular}




\section{Análise multimodal}

3.1. Tipologia das disfluências

\begin{tabular}{|l|c|l|c|}
\hline Disfluências comuns & \multicolumn{2}{l|}{ Disfluências gagas } \\
\hline Hesitação & 0 & Repetição sílaba & 0 \\
\hline Interjeição & 2 & Repetição som & 0 \\
\hline Revisão & 0 & Prolongamento & 0 \\
\hline Palavra incompleta & 0 & Bloqueio & 0 \\
\hline Repetição palavra & 1 & Pausa & 1 \\
\hline Repetição Segmento & 0 & Intrusão som & 0 \\
\hline Repetição frase & 0 & & 1 \\
\hline TOTAL & 3 & TOTAL & \\
\hline
\end{tabular}

3.2. Velocidade de fala

\begin{tabular}{|l|l|}
\hline Fluxo de palavras por minuto & Fluxo de sílabas por minuto \\
\hline $97 / 2,42=$ & $195 / 2,42=$ \\
\hline
\end{tabular}

3.3. Freqüência de rupturas da fala

\begin{tabular}{|l|l|}
\hline \% de descontinuidade de fala & \% de disfluências gagas \\
\hline $4 / 195=$ & $1 / 195=$ \\
\hline $2,05 \%$ & $0,50 \%$ \\
\hline
\end{tabular}


SUJEITO - 2C

NOME: E.F.H.

SEXO: masculino

IDADE: 17 a.

ESCOLARIDADE: $8^{\mathrm{a}}$ série do ensino fundamental

\section{Transcrição da amostra}

1.a. Transcrição padrão

Falá u que? // casa muito sujo nu tem cumida // num sei //

num sei // pobre favela // pobre tem fome não tem cumida num tem cama televisão // treze acho // acho não // fazê nada // só pega cumida da rua // tem // ele num tem // pede ajuda amigo // num tem nada

1.b. Texto expresso Multimodal

Falá u que? Casa muito suja. Nu tem cumida. Num sei. Pobre, favela. Pobre tem fome, não tem cumida, num tem cama, televisão, coisas. Treze acho. Acho não. Fazê nada. Só pega cumida da rua. Tem. Ele num tem. Pede ajuda amigo. Num tem nada. 


\section{Análise - produção oral}

2.1. Tipologia das disfluências

\begin{tabular}{|l|l|l|c|}
\hline Disfluências comuns & \multicolumn{2}{l|}{ Disfluências gagas } \\
\hline Hesitação & 0 & Repetição sílaba & 0 \\
\hline Interjeição & 0 & Repetição som & 0 \\
\hline Revisão & 0 & Prolongamento & 0 \\
\hline Palavra incompleta & 0 & Bloqueio & 0 \\
\hline Repetição palavra & 0 & Pausa & 6 \\
\hline Repetição Segmento & 1 & Intrusão som & 0 \\
\hline Repetição frase & 0 & & 6 \\
\hline TOTAL & 1 & TOTAL & \\
\hline
\end{tabular}

2.2. Velocidade de fala

\begin{tabular}{|l|l|}
\hline Fluxo de palavras por minuto & Fluxo de sílabas por minuto \\
\hline $40 / 2,13=$ & $76 / 2,13=$ \\
\hline
\end{tabular}

2.3. Freqüência de rupturas da fala

\begin{tabular}{|l|lr|}
\hline \% de descontinuidade de fala & \multicolumn{2}{|l|}{ \% de disfluências gagas } \\
\hline $7 / 76=$ & $6 / 76=$ & $7,89 \%$ \\
\hline
\end{tabular}




\section{Análise multimodal}

3.1. Tipologia das disfluências

\begin{tabular}{|l|l|l|c|}
\hline Disfluências comuns & \multicolumn{2}{l|}{ Disfluências gagas } \\
\hline Hesitação & 0 & Repetição sílaba & 0 \\
\hline Interjeição & 0 & Repetição som & 0 \\
\hline Revisão & 0 & Prolongamento & 0 \\
\hline Palavra incompleta & 0 & Bloqueio & 0 \\
\hline Repetição palavra & 0 & Pausa & 6 \\
\hline Repetição Segmento & 1 & Intrusão som & 0 \\
\hline Repetição frase & 0 & & 6 \\
\hline TOTAL & 1 & TOTAL & \\
\hline
\end{tabular}

3.2. Velocidade de fala

\begin{tabular}{|l|l|}
\hline Fluxo de palavras por minuto & Fluxo de sílabas por minuto \\
\hline $41 / 2,13=$ & $78 / 2,13=$ \\
\hline
\end{tabular}

3.3. Freqüência de rupturas da fala

\begin{tabular}{|l|l|}
\hline \% de descontinuidade de fala & \multicolumn{2}{|l|}{ \% de disfluências gagas } \\
\hline $7 / 78=$ & $6 / 78=$ \\
\hline
\end{tabular}




\section{ANEXO D - ANAMNESE}

NOME:

DATA DE NASCIMENTO:

RAÇA:
SEXO:

IDADE ATUAL:

ESCOLARIDADE:

UTILIZOU APARELHO DE AMPLIFICAÇÃO SONORA?

( )SIM ( )NÃO OBS.:

ESTUDOU EM ESCOLA ESPECIAL?

( )SIM ( )NÃO OBS.:

TEVE ACESSO A TERAPIA FONOAUDIOLÓGICA?

( )SIM ( )NÃO OBS.:

TEM ANTECEDENTE FAMILIAR PARA SURDEZ CONGÊNITA?
( ) SIM
( )NÃO
OBS.: 
ANEXO E - PROTOCOLO DE AVALIAÇÃO DA FLUÊNCIA (Andrade, 2000b)

\section{Transcrição da amostra:}

A amostra de fala deve ser transcrita em sua totalidade (sílabas fluentes e disfluentes), segundo os critérios abaixo:

1. Eventos de disfluência: marcados em negrito

2. Seguimento ininteligível:

3. Interrupção da terapeuta: //

4. Hesitação: \#

5. Pausa:

6. Bloqueio: / antes da sílaba bloqueada

7. Prolongamento:_após a sílaba bloqueada

8. Intrusão na palavra: o seguimento de intrusão vem entre / /

Adaptação para amostra de fala de surdo:

1. Articulação sem som: palavra sublinhada

2. Sinal sem som: palavra entre ( )

Análise:

1. Tipologia das disfluências - marcar na linha correspondente o número de ocorrências para cada tipo de disfluência. Somar o número total da tipologia comum e da tipologia gaga separadamente.

Disfluências mais comuns (hesitações, interjeições, revisões, palavras incompletas, repetições de frases). Disfluências gagas (3 ou mais repetições de sons e/ou sílabas e/ou palavras, prolongamentos, bloqueios, pausas).

Hesitações: pausa curta (1 a 2 Seg.) onde parece que o sujeito está procurando a palavra e/ou prolongamentos de vogais usuais (Ex.: é..., ã..., hum...). 
Interjeição: inclusão de sons, palavras ou frases, sem sentido ou irrelevantes no contexto da mensagem (tá, né, assim, como, você sabe, daí, etc.).

Revisão: mudança no conteúdo ou na forma gramatical da mensagem ou na pronúncia da palavra (ela ele pode vir aqui? Ele viu comeu todo o doce/ a menina pa bateu no cachorro).

Palavra incompleta: palavra que é abandonada, não terminada posteriormente. Tipicamente é seguida por uma revisão. No caso da fala do surdo, observamos palavras incompletas sem a sílaba inicial.

Repetição de segmentos: repetição de pelo menos duas palavras completas na mensagem (que dia , que dia bonito).

Repetição de frase: repetição de uma frase completa já expressa.

Repetição de palavra: repetição de uma palavra inteira, incluem-se os monossílabos, as preposições e as conjunções (eu eu preciso de uma caneta/ que que horas são?/ a boneca é da da Maria)

Repetição de sílaba: repetição de uma sílaba inteira ou de uma parte da palavra (eu quero a bababanana/ o poporporco é feio)

Repetição de som: repetição de um fonema ou de um elemento de um ditongo que compõe a palavra (você quer s s s s suco?)

Prolongamento: duração inapropriada de um fonema ou de um elemento de um ditongo, que pode ou não estar acompanhado por características qualitativas da fala (issssso é meu? Sssssai daí)

Bloqueio: tempo inapropriado para iniciar um fonema ou a liberação de uma posição articulatória fixa (boca aberta antes de iniciar a emissão ou tremores faciais antes da emissão, etc.).

Pausa: interrupção do fluxo da fala pelo rompimento temporal da seqüência (mais de 3 segundos para realizar a conexão dos elementos) podendo ou não estar associada a características qualitativas. 
Intrusão: produção de sons ou cadeias de sons não pertinentes ao contexto inter ou entre palavras.

2. Velocidade de fala:

a)Fluxo de palavras por minuto (mede a taxa de produção de informação) - cronometrar o tempo total da amostra, contar o número total de palavras expressas produzidas, aplicar regra para compatibilização por minuto e anotar na linha correspondente.

b)Fluxo de sílabas por minuto (mede a taxa de velocidade articulatória) - cronometrar o tempo total da amostra, contar o número total de sílabas expressas produzidas, aplicar regra de compatibilização por minuto e anotar na linha correspondente.

3. Freqüência de rupturas:

a)Porcentagem de descontinuidade de fala (mede a taxa de rupturas no discurso) - contar o número total de sílabas produzidas na amostra e o número total de rupturas comuns e gagas, aplicar a relação de porcentagem.

b)Porcentagem de disfluências gagas (mede a taxa de rupturas gagas) - contar o número total de sílabas produzidas na amostra e o número total de sílabas gaguejadas (só as de tipologia gaga), aplicar a relação de porcentagem.

4. Categorias específicas para a fala dos surdos:

Articulação sem som: emissão de sílabas, palavras ou segmentos sem a utilização da fonte glótica.

Sinal: uso de LIBRAS no lugar da palavra falada. 
ANEXO F - FIGURA 
ANEXO G - CORPUS - AVALIAÇÃO DA FLUÊNCIA

DADOS DO SUJEITO - 1

NOME: S.L.G.N.

SEXO: feminino

IDADE: 31 anos

ESCOLARIDADE: superior completo

\section{Transcrição da amostra}

\section{1.a. Transcrição padrão}

U minino pobre mora na casa da favela minino sujo certo certo // o

menino tá passandu pobreza fome miséria é a situação do Brasil certo // difícil muita corrupção poderia ter não sei poderia ter ou sei lá difícil fazer //como? // igual assim não igual assim não se vê dormindo na rua cheirando cola mas esse não interior? norte? eu a espero que o norte dá pena de // // promete ter// não eu acho não vai ser difícil pra ele poderá conseguir mas difícil// estudo estudo educação limpeza sei lá um lugar melhor porque ele vai ter que trabalhar mais cedo pra sustentar mãe difícil// não// pena da situação que ele está passando tendeu purque eu num tive ele teve sabe dá

1.b. Texto expresso - multimodal

O menino pobre mora na casa da favela, menino sujo. O menino tá passando pobreza, fome, miséria, é a situação do Brasil. Difícil. Muita corrupção. Poderia ter, não sei, difícil fazer. Igual assim não. Se vê dormindo na rua, cheirando cola, mas esse não. Interior? Norte? Eu espero que o norte. Dá pena de. Promete ter. Não, eu acho não. Vai ser difícil pra ele. Poderá conseguir mas difícil. Estudo, educação, limpeza, um lugar melhor, porque ele vai ter que trabalhar mais cedo pra sustentar mãe, difícil. Não. Pena da situação que ele está passando porque eu num tive, ele teve. Sabe dá 


\section{Análise - produção oral}

2.1. Tipologia das disfluências

\begin{tabular}{|l|c|l|c|}
\hline Disfluências comuns & \multicolumn{2}{l|}{ Disfluências gagas } \\
\hline Hesitação & 0 & Repetição sílabas & 0 \\
\hline Interjeição & 5 & Repetição som & 0 \\
\hline Revisão & 1 & Prolongamento & 0 \\
\hline Palavra incompleta & 2 & Bloqueio & 0 \\
\hline Repetição palavra & 1 & Pausa & 3 \\
\hline Repetição segmento & 2 & Intrusão som & 0 \\
\hline Repetição frase & 0 & & 0 \\
\hline TOTAL & 11 & TOTAL & 3 \\
\hline
\end{tabular}

2.2. Velocidade de fala

\begin{tabular}{|c|c|c|c|}
\hline \multicolumn{2}{|c|}{ Fluxo de palavras por minuto } & \multicolumn{2}{|c|}{ Fluxo de sílabas por minuto } \\
\hline $103 / 1: 56=$ & 66.02 & $200 / 1: 56=$ & 128.20 \\
\hline
\end{tabular}

2.3. Freqüência de rupturas da fala

\begin{tabular}{|c|c|c|c|}
\hline \multicolumn{2}{|c|}{$\%$ de descontinuidade de fala } & \multicolumn{2}{|c|}{ \%de disfluências gagas } \\
\hline $14 / 200=$ & $7,00 \%$ & $3 / 200=$ & $1.50 \%$ \\
\hline
\end{tabular}




\section{Análise multimodal}

3.1. Tipologia das disfluências

\begin{tabular}{|l|c|l|c|}
\hline Disfluências comuns & \multicolumn{2}{l|}{ Disfluências gagas } \\
\hline Hesitação & 0 & Repetição sílabas & 0 \\
\hline Interjeição & 5 & Repetição som & 0 \\
\hline Revisão & 1 & Prolongamento & 0 \\
\hline Palavra incompleta & 2 & Bloqueio & 0 \\
\hline Repetição palavra & 1 & Pausa & 3 \\
\hline Repetição segmento & 2 & Intrusão som & 0 \\
\hline Repetição frase & 0 & & 3 \\
\hline TOTAL & 11 & TOTAL & \\
\hline
\end{tabular}

3.2. Velocidade de fala

\begin{tabular}{|c|c|c|c|}
\hline \multicolumn{2}{|c|}{ Fluxo de palavras por minuto } & \multicolumn{2}{|c|}{ Fluxo de sílabas por minuto } \\
\hline $103 / 1.56=$ & 66.02 & $200 / 1.56=$ & 128.20 \\
\hline
\end{tabular}

3.3. Frequêencia de rupturas da fala

\begin{tabular}{|l|lc|}
\hline \multicolumn{2}{|l|}{ \% de descontinuidade de fala } & \multicolumn{2}{|c|}{ \% de disfluências gagas } \\
\hline $14 / 200=$ & $3 / 200=$ & $1.50 \%$ \\
\hline
\end{tabular}


DADOS DO SUJEITO - 2

NOME: L.M.R.V.

SEXO: masculino

IDADE: 20 anos

ESCOLARIDADE: $3^{\circ}$ ano ensino médio

\section{Transcrição da amostra}

\section{1.a.Transcrição padrão}

O mininu é pobri ele está pensando qué ser crescer o futuro quando ele podi trabalha mas não consegui purque papai a mamãe não ajudo e também não tem dinhero ele está pensando como ele vai fazer no futuro ele precisa estudá escola aprende a vontadi vai faze trabalho é bom para a vida da família ajuda tudo// o mininu fico triste ele não consigo come purque mamãe pepapai

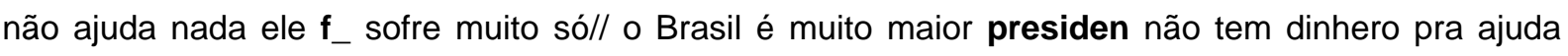
pobri a pobri ficou sozinhu o presita ajuda porque o Brasil é muito maior não dá pra ajuda pobri outro

\section{1.b. Texto expresso - multimodal}

O mininu é pobri. ele está pensando qué ser crescer o futuro. quando ele podi trabalha mas não consegui purque papai a mamãe não ajudo e também não tem dinhero. ele está pensando como ele vai fazer no futuro. ele precisa estudá, escola aprende a vontadi, vai faze trabalho, é bom para a vida da família ajuda tudo. o mininu fico triste. ele não consigo come purque mamãe papai não ajuda nada. ele sofre muito. Só. o Brasil é muito maior, presidente não tem dinhero pra ajuda pobri. a pobri ficou sozinhu. O presidente ajuda porque o Brasil é muito maior não dá pra ajuda pobri outro 


\section{Análise - produção oral}

2.1. Tipologia das disfluências

\begin{tabular}{|l|l|l|c|}
\hline Disfluências comuns & \multicolumn{2}{l|}{ Disfluências gagas } \\
\hline Hesitação & 0 & Repetição sílabas & 1 \\
\hline Interjeição & 0 & Repetição som & 0 \\
\hline Revisão & 0 & Prolongamento & 0 \\
\hline Palavra incompleta & 2 & Bloqueio & 0 \\
\hline Repetição palavra & 0 & Pausa & 3 \\
\hline Repetição Segmento & 0 & Intrusão som & 1 \\
\hline Repetição frase & 0 & & 5 \\
\hline TOTAL & 2 & TOTAL & \\
\hline
\end{tabular}

2.2. Velocidade de fala

\begin{tabular}{|l|l|}
\hline \multicolumn{1}{|l|}{ Fluxo de palavras por minuto } & Fluxo de sílabas por minuto \\
\hline $105 / 1: 42=$ & $200 / 1: 42=$ \\
\hline
\end{tabular}

2.3. Freqüência de rupturas da fala

\begin{tabular}{|l|l|l|}
\hline \multicolumn{2}{|l|}{$\%$ de descontinuidade de fala } & \multicolumn{2}{|l|}{ \% de disfluências gagas } \\
\hline $7 / 200=$ & $5 / 50 \%$ & $5.200=$ \\
\hline
\end{tabular}




\section{Análise multimodal}

3.1. Tipologia das disfluências

\begin{tabular}{|l|l|l|c|}
\hline Disfluências comuns & \multicolumn{2}{l|}{ Disfluências gagas } \\
\hline Hesitação & 0 & Repetição sílabas & 1 \\
\hline Interjeição & 0 & Repetição som & 0 \\
\hline Revisão & 0 & Prolongamento & 0 \\
\hline Palavra incompleta & 0 & Bloqueio & 0 \\
\hline Repetição palavra & 0 & Pausa & 3 \\
\hline Repetição segmento & 0 & Intrusão som & 1 \\
\hline Repetição frase & 0 & & 5 \\
\hline TOTAL & 0 & TOTAL & \\
\hline
\end{tabular}

3.2. Velocidade de fala

\begin{tabular}{|l|lr|}
\hline Fluxo de palavras por minuto & \multicolumn{2}{|l|}{ Fluxo de sílabas por minuto } \\
\hline $107 / 1.42=$ & $208 / 1.42=$ \\
\hline
\end{tabular}

3.3. Freqüência de rupturas da fala

\begin{tabular}{|c|c|c|c|}
\hline \multicolumn{2}{|c|}{$\%$ de descontinuidade de fala } & \multicolumn{2}{|c|}{$\%$ de disfluências gagas } \\
\hline $5 / 208=$ & $2,40 \%$ & $5 / 208=$ & $2,40 \%$ \\
\hline
\end{tabular}


DADOS DO SUJEITO - 3

NOME: E. S.

SEXO: masculino

IDADE: 39 anos

ESCOLARIDADE: ensino médio completo

\section{Transcrição da amostra}

\section{1.a.Transcrição padrão}

Por exemplo contando história // menino mora favelado é difícil de explicar adimirandu fotógrafo tem olhos azuis moreno imundu num tem lugar bom é difícil explicar deve ser mora longe de São Paulo acho Norte pode ser é difícil explicar só is_ // é o que ti falei criança triste passandu fomi nu gostu criança revoltado proble mendigo num gostu é difícil de ajudar // apoiar muito bom precise muito roupas alimentos casa precisa higiênica tudo sujo precisa tudo casa conservada precisa boa alimentação num tem vitamina só // ropa sujo difícil só

1.b. Texto expresso - multimodal

Por exemplo contando história? menino mora favelado, triste sentir, é difícil de explicar. adimirandu fotógrafo. tem olhos azuis, moreno, imundu. num tem lugar bom. deve ser mora longe de São Paulo. acho Norte, pode ser. Só. é o que ti falei, criança triste, passandu fomi, nu gostu criança revoltado, mendigo num gostu. é difícil de ajudar. apoiar muito bom, precise muito roupas, alimentos, casa, precisa higiênica, tudo sujo. precisa tudo. casa conservada, precisa boa alimentação. num tem vitamina. Só. ropa sujo difícil. só 


\section{Análise - produção oral}

2.1. Tipologia das disfluências

\begin{tabular}{|l|l|l|c|}
\hline Disfluências comuns & \multicolumn{2}{l|}{ Disfluências gagas } \\
\hline Hesitação & 0 & Repetição sílabas & 0 \\
\hline Interjeição & 2 & Repetição som & 0 \\
\hline Revisão & 0 & Prolongamento & 0 \\
\hline Palavra incompleta & 2 & Bloqueio & 0 \\
\hline Repetição palavra & 0 & Pausa & 11 \\
\hline Repetição Segmento & 0 & Intrusão som & 0 \\
\hline Repetição frase & 0 & & 11 \\
\hline TOTAL & 4 & TOTAL & \\
\hline
\end{tabular}

2.2. Velocidade de fala

\begin{tabular}{|c|c|c|c|}
\hline \multicolumn{2}{|c|}{ Fluxo de palavras por minuto } & \multicolumn{2}{|c|}{ Fluxo de sílabas por minuto } \\
\hline $81 / 2: 11=$ & 38.38 & $179 / 2: 11=$ & 84.83 \\
\hline
\end{tabular}

2.3. Freqüência de rupturas da fala

\begin{tabular}{|c|c|c|c|}
\hline \multicolumn{2}{|c|}{$\%$ de descontinuidade de fala } & \multicolumn{2}{|c|}{ \% de disfluências gagas } \\
\hline $15 / 179=$ & $8,37 \%$ & $11 / 179=$ & $6.14 \%$ \\
\hline
\end{tabular}




\section{Análise multimodal}

3.1. Tipologia das disfluências

\begin{tabular}{|l|l|l|c|}
\hline Disfluências comuns & \multicolumn{2}{l|}{ Disfluências gagas } \\
\hline Hesitação & 0 & Repetição sílabas & 0 \\
\hline Interjeição & 2 & Repetição som & 0 \\
\hline Revisão & 0 & Prolongamento & 0 \\
\hline Palavra incompleta & 2 & Bloqueio & 0 \\
\hline Repetição palavra & 0 & Pausa & 9 \\
\hline Repetição segmento & 0 & Intrusão som & 0 \\
\hline Repetição frase & 0 & & 9 \\
\hline TOTAL & 4 & TOTAL & \\
\hline
\end{tabular}

3.2. Velocidade de fala

\begin{tabular}{|c|c|c|c|}
\hline \multicolumn{2}{|c|}{ Fluxo de palavras por minuto } & \multicolumn{2}{|c|}{ Fluxo de sílabas por minuto } \\
\hline $83 / 2: 11=$ & 39.38 & $183 / 2.11=$ & 86.72 \\
\hline
\end{tabular}

3.3. Freqüência de rupturas da fala

\begin{tabular}{|l|l|}
\hline \% de descontinuidade de fala & \% de disfluências gagas \\
\hline $13 / 183=$ & $9 / 183=$ \\
\hline
\end{tabular}


DADOS DO SUJEITO - 4

NOME: M.H.H.

SEXO: feminino

IDADE: 32 anos

ESCOLARIDADE: $1^{\circ}$ ano curso superior

\section{Transcrição da amostra}

1.a. Transcrição padrão

o menino é pobre mora na favela ele não tem uma família ela etá pouca de fome poque ele não come e

não tem // ele dinhero para pagar comida porque ele não

trabalha porque pai e mãe abandonou ele para viver sozinho ele sofre muito não tem muito feliz não é no Brasil ser pobre muito porque os políticos acham

melhor preci ajudar muito esse menino para arrumar um emprego para ele um dinhero

para viver melhor quem sabe ele pode trabalhar para para melhorar a vida $\sim \sim \sim \sim \sim \sim / / \mid$

ajuda para arruma um emprego para ganhar um dinhero para viver \#e viver melhor e ter melhor para ser feliz mas não é muito fácil é munti

\section{1.b. Texto expresso multimodal}

difícil falar como? o menino é pobre mora na favela. ele não tem uma família. ele etá pouca de fome poque ele não come e não tem. ele não tem dinheiro para pagar comida porque ele não trabalha porque pai e mãe abandonou ele pra viver sozinho. ele sofre muito, não tem muito feliz. no Brasil ser pobre muito porque os políticos acham melhor precisar ajudar muito esse menino para arrumar um emprego para ele um dinhero para viver melhor quem sabe ele pode trabalhar para melhorar a vida. ajuda para arruma um emprego para ganhar um dinhero para viver melhor e ter melhor. para ser feliz mas não é muito fácil é munti 


\section{Análise - produção oral}

2.1. Tipologia das disfluências

\begin{tabular}{|l|c|l|c|}
\hline Disfluências comuns & \multicolumn{2}{l|}{ Disfluências gagas } \\
\hline Hesitação & 1 & Repetição sílabas & 0 \\
\hline Interjeição & 0 & Repetição som & 0 \\
\hline Revisão & 1 & Prolongamento & 0 \\
\hline Palavra incompleta & 1 & Bloqueio & 0 \\
\hline Repetição palavra & 2 & Pausa & 19 \\
\hline Repetição Segmento & 0 & Intrusão som & 0 \\
\hline Repetição frase & 0 & & 19 \\
\hline TOTAL & 5 & TOTAL & \\
\hline
\end{tabular}

2.2. Velocidade de fala

\begin{tabular}{|c|c|c|c|}
\hline \multicolumn{2}{|c|}{ Fluxo de palavras por minuto } & \multicolumn{2}{|c|}{ Fluxo de sílabas por minuto } \\
\hline $112 / 2: 52=$ & 44.44 & $200 / 2.52=$ & 79.36 \\
\hline
\end{tabular}

2.3. Freqüência de rupturas da fala

\begin{tabular}{|l|l|}
\hline \% de descontinuidade de fala & \% de disfluências gagas \\
\hline $24 / 200=$ & $19 / 200=$ \\
\hline $12,00 \%$ & $9,50 \%$ \\
\hline
\end{tabular}




\section{Análise multimodal}

3.1. Tipologia das disfluências

\begin{tabular}{|l|c|l|c|}
\hline Disfluências comuns & \multicolumn{2}{l|}{ Disfluências gagas } \\
\hline Hesitação & 1 & Repetição sílabas & 0 \\
\hline Interjeição & 3 & Repetição som & 0 \\
\hline Revisão & 1 & Prolongamento & 0 \\
\hline Palavra incompleta & 0 & Bloqueio & 0 \\
\hline Repetição palavra & 2 & Pausa & 10 \\
\hline Repetição segmento & 0 & Intrusão som & 0 \\
\hline Repetição frase & 0 & & 10 \\
\hline TOTAL & 7 & TOTAL & \\
\hline
\end{tabular}

3.2. Velocidade de fala

\begin{tabular}{|l|l|}
\hline Fluxo de palavras por minuto & Fluxo de sílabas por minuto \\
\hline $114 / 2.52=$ & $210 / 2.52=$ \\
\hline
\end{tabular}

3.3. Freqüência de rupturas da fala

\begin{tabular}{|l|l|}
\hline$\%$ de descontinuidade de fala & \multicolumn{2}{|l|}{ \% de disfluências gagas } \\
\hline $17 / 210=$ & $10 / 210=$ \\
\hline
\end{tabular}


DADOS DO SUJEITO - 5

NOME: E.B.A.

SEXO: feminino

IDADE: 34 anos

ESCOLARIDADE: ensino médio compl.

\section{Transcrição da amostra}

1.a.Transcrição padrão

Menino é pobre passa num tem uma familia sempre roba dinhero apoia escola ajuda filho pai mãe pra ele sozinho vive sozinho \#i num tem onde amizade escola família nada só é a ropa preci_frio preci come escola educação falta família só // tem uma ajuda uma não ajuda Febem problema mesma coisa está na rua porque quer liberdade fico preso até cinco anos sai \#i se bom come elebeve bom pego procura pega ensina te educação coisa// gove faz alguma coisa? gove faz nada faz nada faz nada // pega tem uma creche creche estuda ensina come aprende escreve pode futuro uma boa família pra ela pra vida só// fi

\section{1.b. Texto expresso multimodal}

Menino é pobre, passa fome, num tem uma família. Sempre rouba dinheiro Precisa uma pessoa apoia, escola ajuda filho bom, pai, mãe pra ele. Sempre vive sozinho. num tem onde amizade, escola, família, nada, só sujo. É a roupa precisa vestir, frio, precisa come, precisa escola, precisa educação, falta família, só. Tem uma pessoa ajuda, uma não ajuda, como acontece Febem teve problema mesma coisa. Está na rua porque quer liberdade. Ficou preso até cinco anos, sai . Governo se bom, come . Elebeve bom. Mas pessoa pego, precisa procura, pega, ensina ter educação, monti coisa. Faz alguma coisa? Acho faz nada. Acho mãe pega, tem uma creche, estuda, ensina, come, aprende escreve. Pode futuro uma boa família pra ela, pra vida, só. 


\section{Análise - produção oral}

2.1. Tipologia das disfluências

\begin{tabular}{|l|l|l|l|}
\hline Disfluências comuns & \multicolumn{2}{|l|}{ Disfluências gagas } \\
\hline Hesitação & 2 & Repetição sílabas & 0 \\
\hline Interjeição & 0 & Repetição som & 0 \\
\hline Revisão & 0 & Prolongamento & 0 \\
\hline Palavra incompleta & 4 & Bloqueio & 0 \\
\hline Repetição palavra & 2 & Pausa & 27 \\
\hline Repetição segmento & 2 & Intrusão som & 0 \\
\hline Repetição frase & 0 & & 27 \\
\hline \multicolumn{1}{|c|}{ TOTAL } & 10 & TOTAL & \\
\hline
\end{tabular}

2.2. Velocidade de fala

\begin{tabular}{|l|cc|}
\hline Fluxo de palavras por minuto & \multicolumn{2}{|c|}{ Fluxo de sílabas por minuto } \\
\hline $100 / 2.34=$ & $200 / 2: 34=$ & 85.47 \\
\hline
\end{tabular}

2.3. Freqüência de rupturas da fala

\begin{tabular}{|c|c|c|c|c|c|}
\hline \multicolumn{2}{|c|}{$\%$ de descontinuidade de fala } & \multicolumn{4}{|c|}{ \% de disfluências gagas } \\
\hline $37 / 200=$ & $18,50 \%$ & 27 & l & 200 & $=$ \\
\hline & & $13,50 \%$ & & & \\
\hline
\end{tabular}




\section{Análise multimodal}

3.1. Tipologia das disfluências

\begin{tabular}{|l|c|l|c|}
\hline Disfluências comuns & \multicolumn{2}{l|}{ Disfluências gagas } \\
\hline Hesitação & 2 & Repetição sílabas & 0 \\
\hline Interjeição & 0 & Repetição som & 0 \\
\hline Revisão & 0 & Prolongamento & 0 \\
\hline Palavra incompleta & 2 & Bloqueio & 0 \\
\hline Repetição palavra & 1 & Pausa & 2 \\
\hline Repetição segmento & 4 & Intrusão som & 0 \\
\hline Repetição frase & 0 & & 2 \\
\hline TOTAL & 9 & TOTAL & \\
\hline
\end{tabular}

3.2. Velocidade de fala

\begin{tabular}{|l|l|}
\hline Fluxo de palavras por minuto & Fluxo de sílabas por minuto \\
\hline $123 / 2.34=$ & $254 / 2.34=$ \\
\hline
\end{tabular}

3.3. Freqüência de rupturas da fala

\begin{tabular}{|c|c|c|c|}
\hline \multicolumn{2}{|c|}{$\%$ de descontinuidade de fala } & \multicolumn{2}{|c|}{ \% de disfluências gagas } \\
\hline $11 / 254=$ & $4,33 \%$ & $2 / 254=$ & $0.78 \%$ \\
\hline
\end{tabular}


DADOS DO SUJEITO - 6

NOME: S.A.S.

SEXO: masculino

IDADE: 34 anos

ESCOLARIDADE: ensino médio completo

\section{Transcrição da amostra}

1.a.Transcrição padrão

\#é u minino pobre difícil \#é pai mamãe não tem dinhero pra ajudá mininu picisa iscola \#é purque \#é comprá lápis borra cadernu material tudu não dá comprá pai não dá comprá por isso não sudo até grandi não sabi le_sabi na_da só rosca rosca né só \#é num sei explicá // não podi pega sujo a mão isso não podi pega depois fica duenti \#é não toma banhu picisa não tem água achu não tem que água pouca nu sei explicá // eu vejo triste eu vejo eu estou tris porque pobre u menino trabalha na rua ven_di \#é \#u saco lata bate depois dá u homi ele trabalha dinheru pra ele recebi pra ele // não // purque \#é não feliz purque é pobre \#é nu tem nada di coisas nu tem nada só rua pega // não eu acho não governu pra ajudá me

\section{1.b. Texto expresso multimodal}

u minino pobre difícil pai mamãe não tem dinhero pra ajudá mininu picisa iscola purque comprá lápis borracha cadernu material tudu não dá comprá pai por isso não estudou até grandi não sabi le sabi nada só rosca. num sei explicá. não podi pega sujo a mão isso depois fica duenti não toma banhu picisa não tem água achu que água pouca. eu vejo triste, eu estou triste porque pobre u menino trabalha na rua vendi saco lata bate depois dá u homi ele trabalha dinheru pra ele recebi pra ele. Não. purque não feliz purque é pobre nu tem nada di coisas só rua pega. não eu acho não governu pra ajudá 


\section{Análise - produção oral}

2.1. Tipologia das disfluências

\begin{tabular}{|l|c|l|c|}
\hline Disfluências comuns & \multicolumn{2}{l|}{ Disfluências gagas } \\
\hline Hesitação & 10 & Repetição sílabas & 0 \\
\hline Interjeição & 2 & Repetição som & 0 \\
\hline Revisão & 1 & Prolongamento & 3 \\
\hline Palavra incompleta & 3 & Bloqueio & 0 \\
\hline Repetição palavra & 1 & Pausa & 3 \\
\hline Repetição segmento & 2 & Intrusão som & 0 \\
\hline Repetição frase & 3 & & 6 \\
\hline TOTAL & 22 & TOTAL & \\
\hline
\end{tabular}

2.2. Velocidade de fala

\begin{tabular}{|l|l|}
\hline \multicolumn{1}{|l|}{ Fluxo de palavras por minuto } & Fluxo de sílabas por minuto \\
\hline $111 / 2: 31=$ & $200 / 2: 31=$ \\
\hline
\end{tabular}

2.3. Freqüência de rupturas da fala

\begin{tabular}{|c|c|c|c|}
\hline \multicolumn{2}{|c|}{$\%$ de descontinuidade de fala } & \multicolumn{2}{|c|}{ \% de disfluências gagas } \\
\hline $28 / 200=$ & $14,00 \%$ & $6 / 200=$ & $3,00 \%$ \\
\hline
\end{tabular}




\section{Análise multimodal}

3.1. Tipologia das rupturas

\begin{tabular}{|l|c|l|c|}
\hline Disfluências comuns & \multicolumn{2}{l|}{ Disfluências gagas } \\
\hline Hesitação & 10 & Repetição sílabas & 0 \\
\hline Interjeição & 2 & Repetição som & 0 \\
\hline Revisão & 1 & Prolongamento & 3 \\
\hline Palavra incompleta & 0 & Bloqueio & 0 \\
\hline Repetição palavra & 1 & Pausa & 3 \\
\hline Repetição segmento & 2 & Intrusão som & 0 \\
\hline Repetição frase & 3 & & 6 \\
\hline TOTAL & 19 & TOTAL & \\
\hline
\end{tabular}

3.2. Velocidade de fala

\begin{tabular}{|l|l|}
\hline Fluxo de palavras por minuto & \multicolumn{2}{|l|}{ Fluxo de sílabas por minuto } \\
\hline $114 / 2,31=$ & $208 / 2,31=$ \\
\hline
\end{tabular}

3.3. Freqüência de rupturas da fala

\begin{tabular}{|l|l|}
\hline$\%$ de descontinuidade de fala & \% de disfluências gagas \\
\hline $25 / 208=$ & $6 / 208=$ \\
\hline
\end{tabular}


DADOS DO SUJEITO - 7

NOME: F. G.

SEXO: masculino

IDADE: 30 anos

ESCOLARIDADE: ensino médio completo

\section{Transcrição da amostra}

1.a.Transcrição padrão

\#a o menino é pobre sentimento triste falta eu pensei penso qué brincá u carrinhu mas não falta não tem nada o ropa sujo pricisa ropa boa fami boa mas falta fo me num tem dile casa limpo pobre vé ui não tem igual casa bobonitu penso qué só triste maguado num tem sapato tem na pé anda muito doendu suja po dá doença pego pe ajuda pensu só// a difi purque sintu sabendo não pode tuda não tem falta pode consigo otra tudo não paga na pode até talvez meni não gosto muito talvez pensu só// governo? politi governo \#é pode preocupado dedevolvimentu pobre muito ruim governo pensá está mui difici dá ajuda sola fami pobre também filhu tu criança vai istuda mais pote $u$

Brasil pode pala

\section{1.b. Texto expresso multimodal}

Esse o menino é pobre sentimento triste falta eu pensei qué brincá u carrinhu mas não falta não tem nada ropa sujo pricisa ropa boa família boa mas falta come num tem dinheiro casa limpo pobre ruim não tem igual casa bonitu penso qué só triste maguado num tem sapato tem nada pé anda muito doendu suja pode dá doença perigoso precisa ajuda pensu só. purque para sintu sabendo não pode estuda não tem dinheiro falta consigo otra estudo não paga pode até talvez menino não gosto muito talvez governo? politico governo pode preocupado dedevolvimentu pobre muito ruim governo pensá muito está difici dá ajuda escola família pobre também filhu estudo criança vai istuda mais importante u Brasil não pode 


\section{Análise - produção oral}

2.1. Tipologia das disfluências

\begin{tabular}{|l|c|l|c|}
\hline Disfluências comuns & \multicolumn{2}{l|}{ Disfluências gagas } \\
\hline Hesitação & 2 & Repetição sílabas & 1 \\
\hline Interjeição & 3 & Repetição som & 0 \\
\hline Revisão & 1 & Prolongamento & 0 \\
\hline Palavra incompleta & 22 & Bloqueio & 0 \\
\hline Repetição palavra & 0 & Pausa & 8 \\
\hline Repetição segmento & 0 & Intrusão som & 0 \\
\hline Repetição frase & 0 & & 9 \\
\hline TOTAL & 28 & TOTAL & \\
\hline
\end{tabular}

2.2. Velocidade de fala

\begin{tabular}{|l|l|}
\hline Fluxo de palavras por minuto & Fluxo de sílabas por minuto \\
\hline $99 / 1.57=$ & $200 / 1.57=$ \\
\hline
\end{tabular}

2.3. Freqüência de rupturas da fala

\begin{tabular}{|l|l|}
\hline \% de descontinuidade de fala & \% de disfluências gagas \\
\hline $37 / 200=$ & $9 / 200=$ \\
\hline
\end{tabular}




\section{Análise multimodal}

3.1. Tipologia das disfluências

\begin{tabular}{|l|c|l|c|}
\hline Disfluências comuns & \multicolumn{2}{l|}{ Disfluências gagas } \\
\hline Hesitação & 2 & Repetição sílabas & 1 \\
\hline Interjeição & 3 & Repetição som & 0 \\
\hline Revisão & 3 & Prolongamento & 0 \\
\hline Palavra incompleta & 3 & Bloqueio & 0 \\
\hline Repetição palavra & 0 & Pausa & 1 \\
\hline Repetição segmento & 1 & Intrusão som & 0 \\
\hline Repetição frase & 0 & & 2 \\
\hline TOTAL & 12 & TOTAL & \\
\hline
\end{tabular}

3.2. Velocidade de fala

\begin{tabular}{|l|l|}
\hline Fluxo de palavras por minuto & Fluxo de sílabas por minuto \\
\hline $120 / 1.57=76.43$ & $257 / 1.57=$ \\
\hline
\end{tabular}

3.3. Freqüência de rupturas da fala

\begin{tabular}{|c|c|c|c|}
\hline \multicolumn{2}{|c|}{$\%$ de descontinuidade de fala } & \multicolumn{2}{|c|}{ \% de disfluências gagas } \\
\hline $14 / 257=$ & $5,44 \%$ & $2 / 257=$ & $0,77 \%$ \\
\hline
\end{tabular}


DADOS DO SUJEITO - 8

NOME: G.A.Q

IDADE: 23 anos

\section{Transcrição da amostra}

1.a. Transcrição padrão

Fala sobre história? Eu acho menino pobre num tem num tem coisas boas tem problema preci come ropa tem simples \#é \#é mora favela porque mamãe pa rápido filhu num trabalho o ganha pouco salário se pobre então quando quesce então procura vive preci alimentação só só// filho?// depende é muita difícil muito lugar com favela como gove ajuda \#é porque muita rua preci pobre desenvolve vê muito pobre aumenta gover ajuda pra resolve poblema então gover não faz // falta \#é pouco pici iscola num tem peci pra vive come pra vive ropa tudo vai pedi achu//como?// é vê muita gente a pedi dinheru

\section{1.b. Texto expresso multimodal}

Fala sobre história? Eu acho menino pobre num tem coisas boas tem problema precisa come ropa tem casa simples mora favela porque mamãe papai rápido filhu num trabalho o ganha pouco salário natural se pobre então quando quesce procura vive precisa alimentação só. filho? depende é muita difícil ver muito lugar com favela como governo ajuda porque construir muita rua ajudar pobre pra desenvolve vê muito pobre aumenta precisa governo ajuda pra resolve poblema então governo não faz. falta precisa escola educação não pode escola tabalha a hora qualquer lugar ganha muito pouco precisa iscola num tem precisa dinheiro pra vive come ropa tudo vai pedi eu achu. como? é vê muita gente a pedi dinheru 


\section{Análise - produção oral}

2.1. Tipologia das disfluências

\begin{tabular}{|l|c|l|c|}
\hline Disfluências comuns & \multicolumn{2}{l|}{ Disfluências gagas } \\
\hline Hesitação & 7 & Repetição sílabas & 0 \\
\hline Interjeição & 3 & Repetição som & 0 \\
\hline Revisão & 1 & Prolongamento & 0 \\
\hline Palavra incompleta & 10 & Bloqueio & 0 \\
\hline Repetição palavra & 0 & Pausa & 13 \\
\hline Repetição segmento & 2 & Intrusão som & 0 \\
\hline Repetição frase & 0 & & 13 \\
\hline TOTAL & 23 & TOTAL & \\
\hline
\end{tabular}

2.2. Velocidade de fala

\begin{tabular}{|c|c|c|c|}
\hline \multicolumn{2}{|c|}{ Fluxo de palavras por minuto } & \multicolumn{2}{|c|}{ Fluxo de sílabas por minuto } \\
\hline $98 / 2: 19=$ & 44.74 & $200 / 2: 19=$ & 91.32 \\
\hline
\end{tabular}

2.3. Freqüência de rupturas da fala

\begin{tabular}{|l|l|}
\hline$\%$ de descontinuidade de fala & \multicolumn{2}{|l|}{$\%$ de disfluências gagas } \\
\hline $36 / 200=$ & $13 / 200=$ \\
\hline
\end{tabular}




\section{Análise multimodal}

3.1. Tipologia das rupturas

\begin{tabular}{|l|c|l|c|}
\hline Disfluências comuns & \multicolumn{2}{l|}{ Disfluências gagas } \\
\hline Hesitação & 7 & Repetição sílabas & 0 \\
\hline Interjeição & 4 & Repetição som & 0 \\
\hline Revisão & 1 & Prolongamento & 0 \\
\hline Palavra incompleta & 2 & Bloqueio & 0 \\
\hline Repetição palavra & 0 & Pausa & 1 \\
\hline Repetição segmento & 2 & Intrusão som & 0 \\
\hline Repetição frase & 0 & & 1 \\
\hline TOTAL & 16 & TOTAL & \\
\hline
\end{tabular}

3.2. Velocidade de fala

\begin{tabular}{|l|l|}
\hline Fluxo de palavras por minuto & \multicolumn{2}{|l|}{ Fluxo de sílabas por minuto } \\
\hline $108 / 2: 19=$ & $242 / 2.19=$ \\
\hline
\end{tabular}

3.3. Freqüência de rupturas da fala

\begin{tabular}{|l|lr|}
\hline \% de descontinuidade de fala & \multicolumn{2}{|l|}{$\%$ de disfluências gagas } \\
\hline $17 / 242=$ & $1 / 242=$ & $0,41 \%$ \\
\hline
\end{tabular}


DADOS DO SUJEITO - 9

NOME: C.P.O.

IDADE: 19 anos

\section{Transcrição da amostra}

1.a. Transcrição padrão

ele tem roupa com amarelo tem xorti tem sujo tem sapatu pé está sentadu sozi não aparece família tá sozinho está na rua parece lugar sujo sujo vive sempre na rua só sentadu atrás muro

pode pedra nu chão só isso só isso // depende governo cada estado ajuda tem governo preocupação estado depende ajuda criança // falta passa fome cumida falta casa dele falta família // sim falta sola tem sola // sim ipotante para desenvolve para vida comu consi melhora para vida pra ela // não só pidi ismola dinheru // não

\section{1.b. Texto expresso multimodal}

ele tem roupa com amarelo tem xorti tem sujo tem sapatu pé está sentadu sozinho não aparece família tá sozinho está na rua parece lugar sujo parece está triste tudo sujo vive sempre na rua vive só sentadu tem atrás muro pode pedra nu chão só isso depende governo cada estado ajuda tem governo preocupação dinheiro estado depende ajuda criança. falta passa fome cumida falta casa dele falta família. sim falta escola tem, não tem escola. sim ipotante para pensar desenvolve para vida comu conseguir melhora para vida pra ela. não só pidi ismola dinheru. não 


\section{Análise - produção oral}

2.1. Tipologia das disfluências

\begin{tabular}{|l|l|l|l|}
\hline Disfluências comuns & \multicolumn{2}{|l|}{ Disfluências gagas } \\
\hline Hesitação & 0 & Repetição sílabas & 0 \\
\hline Interjeição & 1 & Repetição som & 0 \\
\hline Revisão & 0 & Prolongamento & 0 \\
\hline Palavra incompleta & 4 & Bloqueio & 0 \\
\hline Repetição palavra & 0 & Pausa & 16 \\
\hline Repetição segmento & 0 & Intrusão som & 0 \\
\hline Repetição frase & 0 & & 16 \\
\hline TOTAL & 5 & TOTAL & \\
\hline
\end{tabular}

2.2. Velocidade de fala

\begin{tabular}{|c|c|c|c|}
\hline Fluxo de pal & uto & Fluxo de síla & \\
\hline $86 / 2: 32=$ & 37.06 & $178 / 2: 32=$ & 76.72 \\
\hline
\end{tabular}

2.3. Freqüência de rupturas da fala

\begin{tabular}{|l|l|}
\hline \% de descontinuidade de fala & \% de disfluências gagas \\
\hline $21 / 178=$ & $16 / 178=\quad 8,98 \%$ \\
\hline
\end{tabular}




\section{Análise multimodal}

3.1. Tipologia das disfluências

\begin{tabular}{|l|l|l|l|}
\hline Disfluências comuns & \multicolumn{2}{|l|}{ Disfluências gagas } \\
\hline Hesitação & 0 & Repetição sílabas & 0 \\
\hline Interjeição & 1 & Repetição som & 0 \\
\hline Revisão & 1 & Prolongamento & 0 \\
\hline Palavra incompleta & 0 & Bloqueio & 0 \\
\hline Repetição palavra & 0 & Pausa & 8 \\
\hline Repetição segmento & 0 & Intrusão som & 0 \\
\hline Repetição frase & 0 & & 0 \\
\hline TOTAL & 2 & TOTAL & 8 \\
\hline
\end{tabular}

3.2. Velocidade de fala

\begin{tabular}{|l|l|}
\hline Fluxo de palavras por minuto & \multicolumn{2}{|l|}{ Fluxo de sílabas por minuto } \\
\hline $96 / 2: 32=$ & $200 / 2.32=$ \\
\hline 41.37 & 86.20 \\
\hline
\end{tabular}

3.3. Freqüência de rupturas da fala

\begin{tabular}{|l|l|}
\hline \% de descontinuidade de fala & \% de disfluências gagas \\
\hline $10 / 200=$ & $8 / 200=\quad 4,00 \%$ \\
\hline
\end{tabular}


DADOS DO SUJEITO - 10

NOME: S.S.P.

IDADE: 23 anos

\section{Transcrição da amostra}

1.a. Transcrição padrão

eu falá?// tô vê pessoas as criança boni olho azul muito pobre casa difícil tem um Brasil

pobre difi eu medo gosta mui ele não culpa não

querer cer pobre di sabe eu vê ter

fami de tem etá chora tendeu eu tô vê eu pobre difi mamãe pai pessoas amigo ajuda pode ajuda tô vê drogas tendeu? faço eu? // escola tem poble boa pessoas tô vê

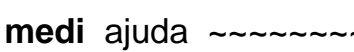
proble sempre fora// mostrar vê pobre pobre só // ele estuda? estuda escola estuda difícil tem pessoas pobre tem preci escola Brasil prese ajuda difi só fala prova presiden presi só vê presi

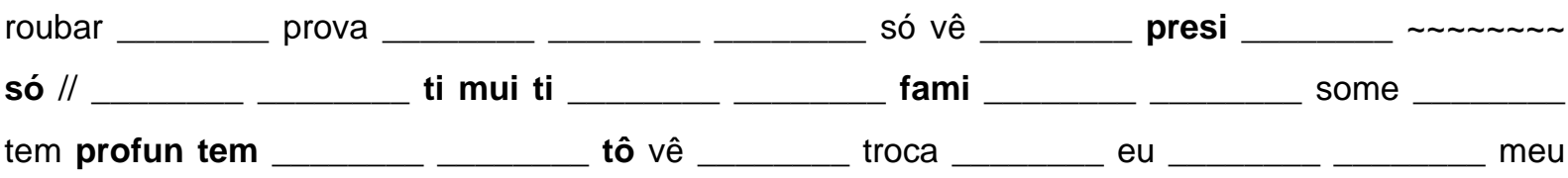
pobre a ru

\section{1.b. Texto expresso multimodal}

Eu falá? Vê pessoas, criança bonita, olho azul, muito pobre, casa difícil tem um Brasil dinheiro problema difícil. Eu medo não. Gosta muito ele. Ele não culpa não , errado, não quer nascer pobre. Dia nascer Deus sabe. Eu vê ter conseguir. Eu filho pobre, difícil, mamãe , pai, família. Ele sofre muito sozinho. Família ajuda onde difícil ele tem. Está chora. Eu vê . Eu ajuda pode não. Eu tem ajuda casa, 
perigoso, confusão pessoas amigo juntos, drogas. Eu que faço eu? Eu vê ele tem problema. Boas pessoas vê pega médico ajuda. Ensina escola ler, aprender, educação certa. Eu liberdade mostrar, ensinar, conseguir problema sempre fora. Eu conhecer muito pobre. Ele estuda? Eu ver ele pobre escola não tem estuda escola junto, cheio. Vê preconceito. Pobre não entrar não. Querer fora. Eu acho ele tem pessoas pobre entrar escola, você diferente. Documento não tem, papai não tem, mamãe não tem. Entrar estudar difícil, conseguir difícil. Tem papai, mamãe, documento igual coisas levar. Tem educação. Ele pobre pode amigo combinar, bater. Ele precisa escola. Brasil presidente ajuda difícil, só dinheiro pego. Mas eu fala prova, não vi presidente roubar , eu não. . Só vê eu fazer presidente fazer. Eu ter muito família ajuda. Pai some, triste tem profunda. tem ele. Eu vê ele troca eu Sandro tem meu, tem pobre a ru

\section{Análise - produção oral}

\subsection{Tipologia das disfluências}

\begin{tabular}{|l|l|l|l|}
\hline Disfluências comuns & \multicolumn{2}{|l|}{ Disfluências gagas } \\
\hline Hesitação & 0 & Repetição sílaba & 0 \\
\hline Interjeição & 3 & Repetição som & 0 \\
\hline Revisão & 0 & Prolongamento & 0 \\
\hline Palavra incompleta & 35 & Bloqueio & 0 \\
\hline Repetição palavra & 3 & Pausa & 88 \\
\hline Repetição segmento & 0 & Intrusão som & 0 \\
\hline Repetição frase & 0 & & 88 \\
\hline TOTAL & 41 & TOTAL & \\
\hline
\end{tabular}


2.2. Velocidade de fala

\begin{tabular}{|l|l|}
\hline Fluxo de palavras por minuto & Fluxo de sílabas por minuto \\
\hline $98 / 3,04=$ & $200 / 3,04=$ \\
\hline
\end{tabular}

2.3. Freqüência de rupturas da fala

\begin{tabular}{|l|l|}
\hline \% de descontinuidade de fala & \% de disfluências gagas \\
\hline $129 / 200=$ & $88 / 200=$ \\
\hline $64,50 \%$ & $44,00 \%$ \\
\hline
\end{tabular}

\section{Análise multimodal}

\subsection{Tipologia das disfluências}

\begin{tabular}{|l|c|l|l|}
\hline Disfluências comuns & \multicolumn{2}{|l|}{ Disfluências gagas } \\
\hline Hesitação & 0 & Repetição sílaba & 0 \\
\hline Interjeição & 3 & Repetição som & 0 \\
\hline Revisão & 1 & Prolongamento & 0 \\
\hline Palavra incompleta & 6 & Bloqueio & 0 \\
\hline Repetição palavra & 3 & Pausa & 0 \\
\hline Repetição segmento & 1 & Intrusão som & 0 \\
\hline Repetição frase & 2 & & 0 \\
\hline TOTAL & 16 & TOTAL & 0 \\
\hline
\end{tabular}


3.2. Velocidade de fala

\begin{tabular}{|l|l|}
\hline \multicolumn{1}{|l|}{ Fluxo de palavras por minuto } & Fluxo de sílabas por minuto \\
\hline $223 / 3,04=$ & $447 / 3,04=$ \\
\hline
\end{tabular}

3.3. Freqüência de rupturas da fala

\begin{tabular}{|l|l|}
\hline \% de descontinuidade de fala & \% de disfluências gagas \\
\hline $16 / 447=$ & $0 / 447=$ \\
\hline $3,57 \%$ & $0 \%$ \\
\hline
\end{tabular}

DADOS DO SUJEITO - 11

NOME: N.G

IDADE: 30 anos

\section{Transcrição da amostra}

1.a. Transcrição padrão

é pobri magui fome come nada vi

nada fome escola nada rua rua casa nu tem pãpã fami

fome

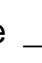
loco

malu rua mãe não en fazê nada quian igual os dois fica na rua só malu joga pe só // acho acho mãe também pobre igual também joga diferente tem mãe glávida depois sabe mãe

loca rua só vai come nada é pobre rua como faz? govê dá dome paga rua só bou pé dinhe // icóla meni escola ne tem vê lá aprende sabe só // precisa govê levá govê pen estudá ape pintá cosa avê mudá pra fome govê dá cumida bom muda vida bom limpu vê govê aju escola aprendê droga nada 
tabalhu tabalhá estudá taba

\section{1.b. Texto expresso multimodal}

Começar? È pobri magui fome come nada vi fora, rua. Casa nu tem mamãe, familia, nada. Foi embora. Fome comer escola nada, rua fica burro. Na rua só maluco andando, louco, droga ver pedir maluco rua. Mãe não ensinou fazê nada. Pensar tanto faz. Depois cresce rouba preso joga crescer. Acho grande criança igual os dois rua. Mãe grávida depois abandonar. Acho mãe também pobre igual. Também joga. Diferente tem mãe abandonar, loca abandonar, crescer, não sabe mãe. Pensar nada escola, rua fome fera, banana pegar dar bebê comer rua qualquer coisa. Só bolsa pegar dinheiro, pega guardar, vai come qualquer coisa. Icola menino escola nu tem. Olha pobre em volta nada. È pobre rua ficar olhando. Tem vê lá aprende sabe escrever nada, como faz? Precisa governo levá aprender, estudá, aprender pintá cosa, desenvolver, mudá roupa. Governo dá roupa, fome governo dá cumida. Vários pratos levar comer. Prato distribuir. Dome pensa crescer bom. Muda vida bom, limpu, depois fora pega governo. Acho paga nada, de graça, ajuda escola aprende desenvolver, droga nada, roubar nada. Educação aprende. Num sabe, crescer aprende, passa crescer bom. Precisa vontade. Qué tabalhu lá, tabalha estuda taba

\section{Análise - produção oral}

\subsection{Tipologia das disfluências}

\begin{tabular}{|l|l|l|c|}
\hline Disfluências comuns & \multicolumn{2}{|l|}{ Disfluências gagas } \\
\hline Hesitação & 0 & Repetição sílaba & 0 \\
\hline Interjeição & 3 & Repetição som & 0 \\
\hline Revisão & 2 & Prolongamento & 1 \\
\hline Palavra incompleta & 17 & Bloqueio & 0 \\
\hline Repetição palavra & 3 & Pausa & 71 \\
\hline Repetição segmento & 1 & Intrusão som & 0 \\
\hline Repetição frase & 0 & & 72 \\
\hline TOTAL & 26 & TOTAL & \\
\hline
\end{tabular}


2.2. Velocidade de fala

\begin{tabular}{|c|c|c|c|}
\hline \multicolumn{2}{|c|}{ Fluxo de palavras por minuto } & \multicolumn{2}{|c|}{ Fluxo de sílabas por minuto } \\
\hline $108 / 2,52=$ & 42,85 & $200 / 2,52=$ & 79,36 \\
\hline
\end{tabular}

2.3. Freqüência de rupturas da fala

\begin{tabular}{|l|ll|}
\hline \% de descontinuidade de fala & \% de disfluências gagas \\
\hline $98 / 200=$ & $72 / 200=$ & $36,00 \%$ \\
\hline
\end{tabular}

\section{Análise multimodal}

\subsection{Tipologia das Disfluências}

\begin{tabular}{|l|c|l|c|}
\hline Disfluências comuns & \multicolumn{2}{|l|}{ Disfluências gagas } \\
\hline Hesitação & 0 & Repetição sílaba & 0 \\
\hline Interjeição & 1 & Repetição som & 0 \\
\hline Revisão & 0 & Prolongamento & 1 \\
\hline Palavra incompleta & 3 & Bloqueio & 0 \\
\hline Repetição palavra & 7 & Pausa & 3 \\
\hline Repetição segmento & 2 & Intrusão som & 0 \\
\hline Repetição frase & 0 & & 4 \\
\hline TOTAL & 13 & TOTAL & \\
\hline
\end{tabular}


3.2. Velocidade de fala

\begin{tabular}{|l|l|}
\hline Fluxo de palavras por minuto & Fluxo de sílabas por minuto \\
\hline $192 / 2,52=$ & $399 / 2,52=$ \\
\hline
\end{tabular}

3.3. Freqüência de rupturas da fala

\begin{tabular}{|l|l|}
\hline \% de descontinuidade de fala & \% de disfluências gagas \\
\hline $17 / 399=$ & $4 / 399=$ \\
\hline
\end{tabular}

DADOS DO SUJEITO - 12

NOME: M.F.A.

IDADE: 23 anos

\section{Transcrição da amostra}

1.a. Transcrição padrão

Eu fala sozinhu? o menino é difícil trabalho puque nu estudô ele foi rua sabe ? vendê chocolate SEXO: masculino ESCOLARIDADE: $3^{\circ}$ ano ensino médio briga quiança muita traba muita ajuda comida coisa mas alto que ele maconha bebe presidente Fernando Henrique ajudá dá escola de graça mas criança não compreensão só isso $\sim \sim \sim \sim \sim \sim$ // o que? // acho não // poque eu vi rua cola num tem idéia picisa é iscola idéia pirigoso duença mas num tem iscola não sei vi vida dele // eu não conheço eu acho pai mãe fora num sei // eu acho que não só ajuda comida só eu vi Xuxa ajuda comida $\mathrm{Gu}$ 


\section{1.b. Texto expresso multimodal}

Eu fala sozinhu? O menino é difícil trabalho puque nu estudô. Ele foi rua dinheiro, sabe chocolate? Vendê chocolate, pedir esmola. Mas alto que ele maconha, bebe, briga, quiança muita trabalhar, muita ajuda, comida, coisa. Quiança é difícil encontá iscola. Picisa presidente Fernando Henrique ajudá dá escola de graça, mas criança não compreensão, só isso. O que? Acho não. Poque eu vi rua, cola, num tem idéia. Picisa é iscola, idéia, pirigoso duença, mas num tem. Depende tem iscola, não sei, vi vida dele. Eu não conheço. Eu acho pai mãe fora. Eu acho que não, só ajuda comida. Só. Eu vi Xuxa ajudô comida, depois Gu

\section{Análise - produção oral}

\subsection{Tipologia das disfluências}

\begin{tabular}{|l|c|l|c|}
\hline Disfluências comuns & \multicolumn{2}{|l|}{ Disfluências gagas } \\
\hline Hesitação & 0 & Repetição sílaba & 0 \\
\hline Interjeição & 2 & Repetição som & 0 \\
\hline Revisão & 0 & Prolongamento & 0 \\
\hline Palavra incompleta & 1 & Bloqueio & 0 \\
\hline Repetição palavra & 0 & Pausa & 16 \\
\hline Repetição segmento & 0 & Intrusão som & 0 \\
\hline Repetição frase & 0 & & 16 \\
\hline TOTAL & 3 & TOTAL & \\
\hline
\end{tabular}

2.2. Velocidade de fala

\begin{tabular}{|c|c|c|c|}
\hline \multicolumn{2}{|c|}{ Fluxo de palavras por minuto } & \multicolumn{2}{|c|}{ Fluxo de sílabas por minuto } \\
\hline $100 / 1,58=$ & 63,29 & $200 / 1,58=$ & 126,58 \\
\hline
\end{tabular}


2.3. Freqüência de rupturas da fala

\begin{tabular}{|c|c|c|c|}
\hline \multicolumn{2}{|c|}{$\%$ de descontinuidade de fala } & \multicolumn{2}{|c|}{$\%$ de disfluências gagas } \\
\hline $19 / 200=$ & $9,50 \%$ & $16 / 200=$ & $8,00 \%$ \\
\hline
\end{tabular}

\section{Análise multimodal}

\subsection{Tipologia das disfluências}

\begin{tabular}{|l|l|l|c|}
\hline Disfluências comuns & \multicolumn{2}{|l|}{ Disfluências gagas } \\
\hline Hesitação & 0 & Repetição sílaba & 0 \\
\hline Interjeição & 3 & Repetição som & 0 \\
\hline Revisão & 0 & Prolongamento & 0 \\
\hline Palavra incompleta & 0 & Bloqueio & 0 \\
\hline Repetição palavra & 0 & Pausa & 9 \\
\hline Repetição segmento & 0 & Intrusão som & 0 \\
\hline Repetição frase & 0 & & 9 \\
\hline TOTAL & 3 & TOTAL & \\
\hline
\end{tabular}

3.2. Velocidade de fala

\begin{tabular}{|l|l|}
\hline \multicolumn{1}{|l|}{ Fluxo de palavras por minuto } & \multicolumn{2}{|l|}{ Fluxo de sílabas por minuto } \\
\hline $106 / 1,58=$ & $214 / 1,58=$ \\
\hline
\end{tabular}

3.3. Freqüência de rupturas da fala

\begin{tabular}{|c|c|c|c|}
\hline \multicolumn{2}{|c|}{$\%$ de descontinuidade de fala } & \multicolumn{2}{|c|}{ \% de disfluências gagas } \\
\hline $12 / 214=$ & $5,60 \%$ & $9 / 214=$ & $4,20 \%$ \\
\hline
\end{tabular}

ANEXO H - TABELAS DE AVALIAÇÃO DOS JUIZES 
Apresentaremos os resultados da análise de concordância entre os juízes quanto à classificação de tipologias. O teste estatístico utilizado foi o Kappa (Siegel,1975). O nível de significância de cada teste foi de $5 \%$.

TABELA H1 - Concordância - Juiz 1 x Juiz 2

\begin{tabular}{lllllll}
\hline & \multicolumn{7}{l}{ Juiz 2} & & \\
\cline { 2 - 7 } & \multicolumn{7}{l}{ Tipologia Presente } & \multicolumn{2}{l}{ Tipologia Ausente } & Total & \\
\cline { 2 - 7 } Juiz 1 & $\mathrm{~N}$ & $\%$ & $\mathrm{~N}$ & $\%$ & $\mathrm{~N}$ & $\%$ \\
\hline Tipologia Presente & 79 & 65,8 & 8 & 6,7 & 87 & 72,5 \\
Tipologia Ausente & 13 & 10,8 & 20 & 16,7 & 33 & 27,5 \\
\hline Total & 92 & 76,7 & 28 & 23,3 & 120 & 100,0 \\
\hline
\end{tabular}

$k=0,5395 / p<0,001$ *

Significante. Há concordância significante entre os juízes.

TABELA H2 - Concordância - Juiz 1 x Juiz 3

\begin{tabular}{lllllll}
\hline & \multicolumn{1}{l}{ Juiz 3} & & & \\
\cline { 2 - 7 } & \multicolumn{2}{l}{ Tipologia Presente } & \multicolumn{2}{l}{ Tipologia Ausente } & \multicolumn{2}{l}{ Total } \\
\cline { 2 - 7 } Juiz 1 & $\mathrm{~N}$ & $\%$ & $\mathrm{~N}$ & $\%$ & $\mathrm{~N}$ & $\%$ \\
\hline Tipologia Presente & 66 & 55,0 & 21 & 17,5 & 87 & 72,5 \\
Tipologia Ausente & 9 & 7,5 & 24 & 20,0 & 33 & 27,5 \\
\hline Total & 75 & 62,5 & 45 & 37,5 & 120 & 100,0 \\
\hline
\end{tabular}

$k=0,4366 / p<0,001$ *

Significante. Há concordância significante entre os juízes. 
TABELA H3 - Concordância - Juiz 2 x Juiz 3

\begin{tabular}{lllllll}
\hline & \multicolumn{3}{l}{ Juiz 3} & & & \\
\cline { 2 - 7 } & \multicolumn{2}{l}{ Tipologia Presente } & \multicolumn{2}{l}{ Tipologia Ausente } & \multicolumn{2}{l}{ Total } \\
\cline { 2 - 7 } Juiz 2 & $\mathrm{N}$ & $\%$ & $\mathrm{~N}$ & $\%$ & $\mathrm{~N}$ & $\%$ \\
\hline Tipologia Presente & 68 & 56,7 & 24 & 20,0 & 92 & 76,7 \\
Tipologia Ausente & 7 & 5,8 & 21 & 17,5 & 28 & 23,3 \\
\hline Total & 75 & 62,5 & 45 & 37,5 & 120 & 100,0 \\
\hline
\end{tabular}

$k=0,4039 / p<0,001$ *

Significante. Há concordância significante entre os juízes. 


\section{ANEXO I - TABELAS GERAIS}

TABELA I1 - Tabela Geral - Produção Oral

\begin{tabular}{ccccccc}
\hline Sujeito & Tipologia das Disfluências & \multicolumn{2}{c}{ Velocidade de Fala } & \multicolumn{2}{c}{ Freqüência de Rupturas } \\
\hline 1 & Comuns & Gagas & $\begin{array}{c}\text { Palavras X } \\
\text { Minuto }\end{array}$ & $\begin{array}{c}\text { Sílabas X } \\
\text { Minuto }\end{array}$ & $\begin{array}{c}\text { \%Desconti- } \\
\text { nuidade Fala }\end{array}$ & $\begin{array}{c}\text { \%Disfluências } \\
\text { Gagas }\end{array}$ \\
\hline 2 & 11 & 3 & 66,02 & 128,20 & 7,00 & 1,50 \\
3 & 2 & 5 & 73,94 & 140,84 & 3,50 & 2,50 \\
4 & 4 & 11 & 38,38 & 84,83 & 8,37 & 6,14 \\
5 & 5 & 19 & 44,44 & 79,36 & 12,00 & 9,50 \\
6 & 10 & 27 & 42,73 & 85,47 & 18,50 & 13,50 \\
7 & 22 & 6 & 48,05 & 86,58 & 14,00 & 3,00 \\
8 & 28 & 9 & 63,05 & 127,38 & 18,50 & 4,50 \\
9 & 23 & 13 & 44,74 & 91,32 & 18,00 & 6,50 \\
10 & 5 & 16 & 37,06 & 76,2 & 11,79 & 8,98 \\
11 & 41 & 88 & 32,23 & 65,8 & 64,50 & 44,00 \\
12 & 26 & 72 & 42,85 & 79,36 & 49,00 & 36,00 \\
\hline TOTAL & 18 & 16 & 63,29 & 126,58 & 9,50 & 8,00 \\
\hline Média & 15,0 & 23,75 & 49,73 & 97,70 & 19,55 & 12,01 \\
\hline & & & & & & 144,12 \\
\hline
\end{tabular}

$\mathrm{Na}$ tabela 11 estão descritos os resultados gerais relativos à produção oral. Quanto à tipologia das disfluências, observa-se maior ocorrência de disfluências gagas que disfluências comuns, sendo a média de 23,75 disfluências gagas e 15,00 disfluências comuns. Quanto à velocidade de fala, observa-se que a média dos sujeitos para a produção de palavras por minuto é de 49,73 e de sílabas por minuto é de 97,70 . Quanto a freqüência de rupturas da fala, observa-se que a porcentagem de descontinuidade da fala é de 19,55 e a porcentagem de disfluências gagas é de 12,01. 
TABELA I2 - Velocidade de Fala - Produção Oral

\begin{tabular}{ccc}
\hline Sujeito & \multicolumn{2}{c}{ Velocidade de Fala } \\
\hline 1 & Palavra X Minuto & Sílaba X Minuto \\
\hline 2 & 66,02 & 128,20 \\
3 & 73,94 & 140,84 \\
4 & 38,38 & 84,83 \\
5 & 44,44 & 79,36 \\
6 & 42,73 & 85,47 \\
7 & 48,05 & 86,58 \\
8 & 63,05 & 127,38 \\
9 & 44,74 & 91,32 \\
10 & 37,06 & 76,72 \\
11 & 32,23 & 65,78 \\
12 & 42,85 & 79,36 \\
\hline TOTAL & 63,29 & 126,58 \\
\hline Média & 596,78 & 1172,42 \\
\hline
\end{tabular}

$\mathrm{Na}$ tabela 12 está descrita a velocidade de fala na produção oral, sendo a média de palavras por minuto de 49,73 e a de sílabas por minuto de 97,70 . 
TABELA I3 - Tipologia Comum - Produção Oral

\begin{tabular}{|c|c|c|c|c|c|c|c|c|}
\hline \multirow[t]{2}{*}{ Sujeito } & \multicolumn{7}{|c|}{ Tipologia Comum } & \multirow[t]{2}{*}{ TOTAL } \\
\hline & Hesitação & Interjeição & Revisão & $\begin{array}{c}\text { Palavra } \\
\text { Incompleta }\end{array}$ & $\begin{array}{c}\text { Repetição } \\
\text { Palavra }\end{array}$ & $\begin{array}{l}\text { Repetição } \\
\text { Segmento }\end{array}$ & $\begin{array}{c}\text { Repetição } \\
\text { Frase }\end{array}$ & \\
\hline 1 & 0 & 5 & 1 & 2 & 1 & 2 & 0 & 11 \\
\hline 2 & 0 & 0 & 0 & 2 & 0 & 0 & 0 & 2 \\
\hline 3 & 0 & 2 & 0 & 2 & 0 & 0 & 0 & 4 \\
\hline 4 & 1 & 0 & 1 & 1 & 2 & 0 & 0 & 5 \\
\hline 5 & 2 & 0 & 0 & 4 & 2 & 2 & 0 & 10 \\
\hline 6 & 10 & 2 & 1 & 3 & 1 & 2 & 3 & 22 \\
\hline 7 & 2 & 3 & 1 & 22 & 0 & 0 & 0 & 28 \\
\hline 8 & 7 & 3 & 1 & 10 & 0 & 2 & 0 & 23 \\
\hline 9 & 0 & 1 & 0 & 4 & 0 & 0 & 0 & 5 \\
\hline 10 & 0 & 3 & 0 & 35 & 3 & 0 & 0 & 41 \\
\hline 11 & 0 & 3 & 2 & 17 & 3 & 1 & 0 & 26 \\
\hline 12 & 0 & 2 & 0 & 1 & 0 & 0 & 0 & 3 \\
\hline TOTAL & 22 & 24 & 7 & 103 & 12 & 9 & 3 & 180 \\
\hline Média & 1,83 & 2 & 0,58 & 8,58 & 1 & 0,75 & 0,25 & 15,00 \\
\hline
\end{tabular}

$\mathrm{Na}$ tabela 13 estão descritos os tipos de disfluências comuns presentes na produção oral. A disfluência comum mais freqüente é a palavra incompleta, com média de 8,58 ocorrências, seguida da hesitação e interjeição, com média de 2 ocorrências cada uma. 
TABELA 14 - Tipologia Gaga - Produção Oral

\begin{tabular}{|c|c|c|c|c|c|c|c|}
\hline \multirow[t]{2}{*}{ Sujeito } & \multicolumn{6}{|c|}{ Tipologia Gaga } & \multirow[t]{2}{*}{ TOTAL } \\
\hline & $\begin{array}{l}\text { Repetição } \\
\text { Sílaba }\end{array}$ & $\begin{array}{c}\text { Repetição } \\
\text { Som }\end{array}$ & Prolongamento & Bloqueio & Pausa & $\begin{array}{l}\text { Intrusão } \\
\text { Som }\end{array}$ & \\
\hline 1 & 0 & 0 & 0 & 0 & 3 & 0 & 3 \\
\hline 2 & 1 & 0 & 0 & 0 & 3 & 1 & 5 \\
\hline 3 & 0 & 0 & 0 & 0 & 11 & 0 & 11 \\
\hline 4 & 0 & 0 & 0 & 0 & 19 & 0 & 19 \\
\hline 5 & 0 & 0 & 0 & 0 & 27 & 0 & 27 \\
\hline 6 & 0 & 0 & 3 & 0 & 3 & 0 & 6 \\
\hline 7 & 1 & 0 & 0 & 0 & 8 & 0 & 9 \\
\hline 8 & 0 & 0 & 0 & 0 & 13 & 0 & 13 \\
\hline 9 & 0 & 0 & 0 & 0 & 16 & 0 & 16 \\
\hline 10 & 0 & 0 & 0 & 0 & 88 & 0 & 88 \\
\hline 11 & 0 & 0 & 1 & 0 & 71 & 0 & 72 \\
\hline 12 & 0 & 0 & 0 & 0 & 16 & 0 & 16 \\
\hline TOTAL & 2 & 0 & 4 & 0 & 278 & 1 & 285 \\
\hline Média & 0,16 & 0 & 0,33 & 0 & 23,16 & 0,08 & 23,75 \\
\hline
\end{tabular}

$\mathrm{Na}$ tabela 14, estão descritas as disfluências gagas presentes na produção oral, sendo as pausas as mais freqüentes, com média de 23,16 ocorrências, seguida pelos prolongamentos, com média de 0,33 e pelas repetições de sílabas, com média de 0,16 ocorrências. 
TABELA I5 - Freqüência de Rupturas - Produção Oral

\begin{tabular}{ccc}
\hline Sujeito & \multicolumn{2}{c}{ Freqüência de Rupturas } \\
\hline 1 & \% Descontinuidade de Fala & \% Disfluências Gagas \\
\hline 2 & 7,00 & 1,50 \\
3 & 3,50 & 2,50 \\
4 & 8,37 & 6,14 \\
5 & 12,00 & 9,50 \\
6 & 18,50 & 13,50 \\
7 & 14,00 & 3,00 \\
8 & 18,50 & 4,50 \\
9 & 18,00 & 6,50 \\
10 & 11,79 & 8,98 \\
11 & 64,50 & 44,00 \\
12 & 49,00 & 36,00 \\
\hline TOTAL & 9,50 & 8,00 \\
\hline Média & 234,66 & 144,12 \\
\hline & 19,55 & 12,01 \\
\hline & & \\
\hline
\end{tabular}

$\mathrm{Na}$ tabela 15 está descrita a freqüência de ruptura da fala na produção oral, sendo a média da taxa de descontinuidade de fala de $19,55 \%$ e a média da taxa de disfluências gagas de 12,01\%. 
TABELA 16 - Tabela Geral - Produção Multimodal

\begin{tabular}{ccccccc}
\hline Sujeito & Tipologia das Disfluências & \multicolumn{2}{c}{ Velocidade de Fala } & \multicolumn{2}{c}{ Freqüência de Rupturas } \\
\hline 1 & Comuns & Gagas & $\begin{array}{c}\text { Palavra X } \\
\text { Minuto }\end{array}$ & $\begin{array}{c}\text { Sílabas X } \\
\text { Minuto }\end{array}$ & $\begin{array}{c}\text { \% Descontinui- \%Disfluências } \\
\text { dade Fala }\end{array}$ & Gagas \\
\hline 2 & 11 & 3 & 66,02 & 128,20 & 7,00 & 1,50 \\
3 & 0 & 5 & 75,35 & 146,47 & 2,40 & 2,40 \\
4 & 4 & 9 & 39,38 & 86,72 & 7,10 & 4,91 \\
5 & 7 & 10 & 45,23 & 83,33 & 8,09 & 4,76 \\
6 & 9 & 2 & 52,56 & 108,54 & 4,33 & 0,78 \\
7 & 19 & 6 & 49,35 & 90,04 & 12,01 & 2,88 \\
8 & 12 & 2 & 76,43 & 163,69 & 5,44 & 0,77 \\
9 & 16 & 1 & 49,31 & 110,50 & 7,02 & 0,41 \\
10 & 2 & 8 & 41,37 & 86,20 & 5,00 & 4,00 \\
11 & 16 & 0 & 73,75 & 147,03 & 3,57 & 0,00 \\
12 & 13 & 4 & 76,19 & 158,33 & 4,26 & 1,00 \\
\hline TOTAL & 3 & 9 & 67,08 & 135,44 & 5,60 & 4,20 \\
\hline Média & 112 & 59 & 712,02 & 1444,49 & 71,82 & 27,61 \\
\hline
\end{tabular}

Na tabela 16 estão descritos os resultados gerais relativos à produção multimodal. Quanto à tipologia das disfluências, observa-se maior ocorrência de disfluências comuns que disfluências gagas, sendo a média de 9,33 disfluências comuns e 4,91 de gagas. Quanto à velocidade de fala, observa-se que a média dos sujeitos para a produção de palavras por minuto é de 59,33 e de sílabas por minuto é de 120,37 . Quanto à freqüência de rupturas da fala, observa-se que a porcentagem média de descontinuidade de fala é de $5,98 \%$ e a porcentagem média de disfluências gagas é de $2,30 \%$. 
TABELA 17 - Velocidade de Fala - Produção Multimodal

\begin{tabular}{ccc}
\hline Sujeito & \multicolumn{2}{c}{ Velocidade de Fala } \\
\hline 1 & Palavra X Minuto & Sílaba X Minuto \\
\hline 2 & 66,02 & 128,20 \\
3 & 73,35 & 146,47 \\
4 & 39,38 & 86,72 \\
5 & 45,23 & 83,33 \\
6 & 52,56 & 108,54 \\
7 & 49,35 & 90,04 \\
8 & 76,43 & 163,69 \\
9 & 49,31 & 110,50 \\
10 & 41,37 & 86,20 \\
11 & 73,75 & 147,03 \\
12 & 76,19 & 158,33 \\
\hline TOTAL & 67,08 & 135,44 \\
\hline Média & 712,02 & 1444,49 \\
\hline & 59,33 & 120,37 \\
\hline & & \\
\hline
\end{tabular}

$\mathrm{Na}$ tabela 17 está descrita a velocidade de fala na produção multimodal, sendo a média de palavras por minuto de 59,33 e a de sílabas por minuto de 120,37. 
TABELA 18 - Tipologia Comum - Produção Multimodal

\begin{tabular}{|c|c|c|c|c|c|c|c|c|}
\hline \multirow[t]{2}{*}{ Sujeito } & \multicolumn{7}{|c|}{ Tipologia Comum } & \multirow[t]{2}{*}{ TOTAL } \\
\hline & Hesitação & Interjeição & Revisão & $\begin{array}{c}\text { Palavra } \\
\text { Incompleta }\end{array}$ & $\begin{array}{c}\text { Repetição } \\
\text { Palavra }\end{array}$ & $\begin{array}{l}\text { Repetição } \\
\text { Segmento }\end{array}$ & $\begin{array}{c}\text { Repetição } \\
\text { Frase }\end{array}$ & \\
\hline 1 & 0 & 5 & 1 & 2 & 1 & 2 & 0 & 11 \\
\hline 2 & 0 & 0 & 0 & 0 & 0 & 0 & 0 & 0 \\
\hline 3 & 0 & 2 & 0 & 2 & 0 & 0 & 0 & 4 \\
\hline 4 & 1 & 3 & 1 & 0 & 2 & 0 & 0 & 7 \\
\hline 5 & 2 & 0 & 0 & 2 & 1 & 4 & 0 & 9 \\
\hline 6 & 10 & 2 & 1 & 0 & 1 & 2 & 3 & 19 \\
\hline 7 & 2 & 3 & 3 & 3 & 0 & 1 & 0 & 12 \\
\hline 8 & 7 & 4 & 1 & 2 & 0 & 2 & 0 & 16 \\
\hline 9 & 0 & 1 & 1 & 0 & 0 & 0 & 0 & 2 \\
\hline 10 & 0 & 3 & 1 & 6 & 3 & 1 & 2 & 16 \\
\hline 11 & 0 & 1 & 0 & 3 & 7 & 2 & 0 & 13 \\
\hline 12 & 0 & 3 & 0 & 0 & 0 & 0 & 0 & 3 \\
\hline TOTAL & 22 & 27 & 9 & 20 & 15 & 14 & 5 & 112 \\
\hline Média & 1,83 & 2,25 & 0,75 & 1,66 & 1,25 & 1,16 & 0,41 & 9,33 \\
\hline
\end{tabular}

$\mathrm{Na}$ tabela 18 estão descritos os tipos de disfluências comuns presentes na produção multimodal. A disfluência comum mais freqüente é a interjeição, com média de 2,25 ocorrências, seguida da hesitação, média de 1,83 ocorrências, e palavra incompleta, com média de 1,66 ocorrências. 
TABELA 19 - Tipologia Gaga - Produção Multimodal

\begin{tabular}{|c|c|c|c|c|c|c|c|}
\hline \multirow[t]{2}{*}{ Sujeito } & \multicolumn{6}{|c|}{ Tipologia Gaga } & \multirow[t]{2}{*}{ TOTAL } \\
\hline & $\begin{array}{c}\text { Repetição } \\
\text { Sílaba }\end{array}$ & $\begin{array}{c}\text { Repetição } \\
\text { Som }\end{array}$ & Prolongamento & Bloqueio & Pausa & $\begin{array}{c}\text { Intrusão } \\
\text { Som }\end{array}$ & \\
\hline 1 & 0 & 0 & 0 & 0 & 3 & 0 & 3 \\
\hline 2 & 1 & 0 & 0 & 0 & 3 & 1 & 5 \\
\hline 3 & 0 & 0 & 0 & 0 & 9 & 0 & 9 \\
\hline 4 & 0 & 0 & 0 & 0 & 10 & 0 & 10 \\
\hline 5 & 0 & 0 & 0 & 0 & 2 & 0 & 2 \\
\hline 6 & 0 & 0 & 3 & 0 & 3 & 0 & 6 \\
\hline 7 & 1 & 0 & 0 & 0 & 1 & 0 & 2 \\
\hline 8 & 0 & 0 & 0 & 0 & 1 & 0 & 1 \\
\hline 9 & 0 & 0 & 0 & 0 & 8 & 0 & 8 \\
\hline 10 & 0 & 0 & 0 & 0 & 0 & 0 & 0 \\
\hline 11 & 0 & 0 & 1 & 0 & 3 & 0 & 4 \\
\hline 12 & 0 & 0 & 0 & 0 & 9 & 0 & 9 \\
\hline TOTAL & 2 & 0 & 4 & 0 & 52 & 1 & 59 \\
\hline Média & 0,16 & 0 & 0,33 & 0 & 4,33 & 0,08 & 4,91 \\
\hline
\end{tabular}

Na tabela 19, estão descritas as disfluências gagas presentes na produção multimodal, sendo as pausas as mais freqüentes, com média de 4,33 ocorrências, seguida pelos prolongamentos, com média de 0,33 e pelas repetições de sílabas, com média de 0,16 ocorrências. 
TABELA 110 - Freqüência de Rupturas - Produção Multimodal

\begin{tabular}{ccc}
\hline Sujeito & \multicolumn{2}{c}{ Freqüência de Rupturas } \\
\hline 1 & \% descontinuidade de fala & \% disfluências gagas \\
\hline 2 & 7,00 & 1,50 \\
3 & 2,40 & 2,40 \\
4 & 7,10 & 4,91 \\
5 & 8,09 & 4,76 \\
6 & 4,33 & 0,78 \\
7 & 12,01 & 2,88 \\
8 & 5,44 & 0,77 \\
9 & 7,02 & 0,41 \\
10 & 5,00 & 4,00 \\
11 & 3,57 & 0,00 \\
12 & 4,26 & 1,00 \\
\hline TOTAL & 5,60 & 4,20 \\
\hline Média & 71,82 & 27,61 \\
\hline & 5,98 & 2,30 \\
\hline & & \\
\hline
\end{tabular}

$\mathrm{Na}$ tabela 110 , estão descritas as freqüências de rupturas da fala na produção multimodal, sendo a média descontinuidade de fala de 5,98\% e a de disfluências gagas de 2,30\%. 
TABELA 111 - Velocidade de fala - Produção Oral X Multimodal

\begin{tabular}{ccccc}
\hline \multicolumn{2}{c}{ Sujeito } & \multicolumn{2}{c}{ Selocidadaba X Minuto } \\
\hline & Oral & Multimodal & Oral & Multimodal \\
\hline 1 & 66,02 & 66,02 & 128,20 & 128,20 \\
2 & 73,94 & 75,35 & 140,84 & 146,47 \\
3 & 38,38 & 39,38 & 84,83 & 86,72 \\
4 & 44,44 & 45,23 & 79,36 & 83,33 \\
5 & 42,73 & 52,26 & 85,47 & 108,54 \\
6 & 48,05 & 49,35 & 86,58 & 90,04 \\
7 & 63,05 & 76,43 & 127,38 & 163,69 \\
8 & 44,74 & 49,31 & 91,32 & 110,50 \\
9 & 37,06 & 41,37 & 76,72 & 86,20 \\
10 & 32,23 & 73,75 & 65,78 & 147,03 \\
11 & 42,85 & 76,19 & 79,36 & 158,33 \\
12 & 63,29 & 67,08 & 126,58 & 135,44 \\
\hline TOTAL & 596,78 & 712,02 & 1172,42 & 1444,49 \\
\hline Média & 49,73 & 59,33 & 97,70 & 120,37 \\
\hline
\end{tabular}

$\mathrm{Na}$ tabela 111 são comparados os dados de velocidade de fala encontrados na produção oral e na produção multimodal. Quanto ao número de palavras por minuto, observa-se que na produção multimodal a média é maior que na produção oral, sendo de 59,33 e 49,73 respectivamente.

O mesmo pode ser observado ao compararmos a média de sílabas por minuto, sendo de 120,37 na produção multimodal e 97,70 na produção oral. 
TABELA 112 - Tipologia das Disfluências - Produção Oral X Multimodal

\begin{tabular}{ccccc}
\hline Sujeito & \multicolumn{2}{l}{ Tipologia das Disfluências } & \\
\hline & Comuns & & Gagas & \\
\hline 1 & 11 & Multimodal & Oral & Multimodal \\
\hline 2 & 2 & 11 & 3 & 3 \\
3 & 4 & 0 & 5 & 5 \\
4 & 5 & 4 & 11 & 9 \\
5 & 10 & 7 & 19 & 10 \\
6 & 22 & 9 & 27 & 2 \\
7 & 28 & 19 & 6 & 2 \\
8 & 23 & 12 & 9 & 1 \\
9 & 5 & 16 & 13 & 8 \\
10 & 41 & 2 & 16 & 0 \\
11 & 26 & 16 & 88 & 4 \\
12 & 3 & 13 & 72 & 59 \\
\hline TOTAL & 180 & 3 & 16 & 4,91 \\
\hline Média & 15,00 & 112 & 285 & 9 \\
\hline
\end{tabular}

$\mathrm{Na}$ tabela 112 são comparados os dados da tipologia das disfluências na produção oral e multimodal. Quanto às disfluências comuns observa-se na produção oral maior ocorrência se comparada com a produção multimodal, sendo as médias 15,00 e 9,33 respectivamente. O mesmo ocorre quanto às disfluências gagas, ocorrendo a média de 23,75 na produção oral contra 4,91 na produção multimodal. Na produção oral observa-se ainda maior ocorrência de disfluências gagas que disfluências comuns, ocorrendo o inverso na produção multimodal. 
TABELA I13 - Freqüência de Rupturas - Produção Oral X Multimodal

\begin{tabular}{|c|c|c|c|c|}
\hline \multirow[t]{3}{*}{ Sujeito } & \multicolumn{2}{|c|}{ Taxa de Rupturas } & & \\
\hline & \multicolumn{2}{|c|}{$\%$ Descontinuidade de Fala } & \multicolumn{2}{|c|}{ \% Disfluências Gagas } \\
\hline & Oral & Multimodal & Oral & Multimoda \\
\hline 1 & 7,00 & 7,00 & 1,50 & 1,50 \\
\hline 2 & 3,50 & 2,40 & 2,50 & 2,40 \\
\hline 3 & 8,37 & 7,10 & 6,14 & 4,91 \\
\hline 4 & 12,00 & 8,09 & 9,50 & 4,76 \\
\hline 5 & 18,50 & 4,33 & 13,50 & 0,78 \\
\hline 6 & 14,00 & 12,01 & 3,00 & 2,88 \\
\hline 7 & 18,50 & 5,44 & 4,50 & 0,77 \\
\hline 8 & 18,00 & 7,02 & 6,50 & 0,41 \\
\hline 9 & 11,79 & 5,00 & 8,98 & 4,00 \\
\hline 10 & 64,50 & 3,57 & 44,00 & 0,00 \\
\hline 11 & 49,00 & 4,26 & 36,00 & 1,00 \\
\hline 12 & 9,50 & 5,60 & 8,00 & 4,20 \\
\hline TOTAL & 234,66 & 71,82 & 144,12 & 27,61 \\
\hline Média & 19,55 & 5,98 & 12,01 & 2,30 \\
\hline
\end{tabular}

$\mathrm{Na}$ tabela 113, são comparados os dados da freqüência de rupturas da fala entre a produção oral e a multimodal. Quanto à porcentagem de descontinuidade de fala, observa-se maior média na produção oral, $19,55 \%$, se comparada com a multimodal, 5,98\%. O mesmo pode ser observado quanto à porcentagem de disfluências gagas, sendo 12,01\% a média na produção oral, e 2,30\% na produção multimodal. 